\title{
A Scoping Review of the Relationship between Running and Mental Health
}

\author{
Freya Oswald ${ }^{1, * \mathbb{C}}$, Jennifer Campbell ${ }^{1} \mathbb{1}$, Chloë Williamson ${ }^{2}$, Justin Richards ${ }^{3}$ and Paul Kelly ${ }^{2}$ \\ 1 Edinburgh Medical School, The University of Edinburgh, Edinburgh EH16 4TJ, UK; s1604637@sms.ed.ac.uk \\ 2 Physical Activity for Health Research Centre (PAHRC), University of Edinburgh, Edinburgh EH8 8AQ, UK; \\ chloe.williamson@ed.ac.uk (C.W.); p.kelly@ed.ac.uk (P.K.) \\ 3 Faculty of Health, Victoria University Wellington, Wellington 6140, New Zealand; justin.richards@vuw.ac.nz \\ * Correspondence: s1504283@sms.ed.ac.uk
}

Received: 10 October 2020; Accepted: 29 October 2020; Published: 1 November 2020

\begin{abstract}
Poor mental health contributes significantly to global morbidity. The evidence regarding physical benefits of running are well-established. However, the mental health impacts of running remain unclear. An overview of the relationship between running and mental health has not been published in the last 30 years. The purpose of this study was to review the literature on the relationship between running and mental health. Our scoping review used combinations of running terms (e.g., Run* and Jog*) and mental health terms (general and condition specific). Databases used were Ovid(Medline), Ovid(Embase), ProQuest and SportDiscus. Quantitative study types reporting on the relationships between running and mental health were included. Database searches identified 16,401 studies; 273 full-texts were analysed with 116 studies included. Overall, studies suggest that running bouts of variable lengths and intensities, and running interventions can improve mood and mental health and that the type of running can lead to differential effects. However, lack of controls and diversity in participant demographics are limitations that need to be addressed. Cross-sectional evidence shows not only a range of associations with mental health but also some associations with adverse mental health (such as exercise addiction). This review identified extensive literature on the relationship between running and mental health.
\end{abstract}

Keywords: exercise; mental health; psychology; physical activity; running; jogging

\section{Introduction}

Poor mental health contributes significantly to the global health burden [1]. The strain of mental health and behavioural disorders is estimated to account for more years of lived disability than any other chronic health ailment [1,2]. The global proportion of disability-adjusted life years caused by mental ill-health has increased from $12.7 \%$ to $14 \%$ (males) and $13.6 \%$ to $14.4 \%$ (females) from 2007 to 2017 [3]. Due to the burden and increasing prevalence of mental ill-health, effective management of mental health disorders is vital [4].

There is substantial evidence to support the relationship between physical activity (PA) and various mental health outcomes across the lifespan [5-7]. There has been investigation of low-intensity PA on mental health; for example, Kelly et al. (2018) reported the positive relationships between walking and mental health in an earlier scoping review [8]. However, a similar synthesis for higher-intensity PA such as running has not been reported.

While the evidence base for the benefits of running on physical health is well-established, the mental health changes from running remain unclear. Addressing the gap within this knowledge is valuable as running is a form of PA popular among many population groups [9]. Inclusive organisations such as "Couch to 5k" [10], "Girls on the run" [11] and "Parkrun" can support running while promoting 
well-being and satisfaction with physical health, facilitating socialisation and community connectedness, and reducing loneliness [12-14]. In primary care settings, national initiatives such as "Parkrun-Practice" promote well-being through running [15].

In recent years, there has been a transition within healthcare to focus on disease morbidity rather than disease mortality, in particular with a drive to improve global mental health [16]. There is increasing prevalence of mental ill-health; therefore, effective management of mental health disorders is vital [4]. In order to investigate any differences in mental health effects between high and low intensities of running, all genres of running must be considered including jogging, sprinting, marathon running and orienteering.

To the best of the authors' knowledge, no recent reviews of the relationship between running and mental health are available. The synthesis provided by this review will enable healthcare practitioners, psychologists and policy makers to better advise on running for mental health. It will also identify key gaps in the literature for future research. The aims of this scoping review are the following:

(1) to provide an overview of what is known regarding the relationship between running and mental health outcomes in all age groups and populations

(2) to highlight current knowledge gaps and research priorities

\section{Materials and Methods}

A scoping review was concluded to be the most appropriate to address the research aims as it provides an overview of the volume and distribution of the evidence base as well as highlights where more research is warranted. The review followed the five-stage scoping review framework proposed by Arksey and O'Malley and was guided by the Preferred Reporting Items for Systematic Reviews and Meta-Analyses (PRISMA) scoping review extension checklist (Appendix A) $[17,18]$.

\subsection{Identify Research Question}

Research questions were developed to address the research aims: "What is known about the effects of running on mental health outcomes?" and "What are the current knowledge gaps?". Research question formulation was guided by item 4 in the PRISMA scoping review extension checklist (Appendix A). The definition of running included jogging, sprinting, marathon running, orienteering and treadmill running. A wide range of intensities were included as the aim of the scoping review was to provide an overall picture of the relationship between running (of various intensities) and mental health.

\subsection{Identify Relevant Outcomes}

Mental health outcomes were informed by Kelly et al. (2018) [8], who reviewed the relationships between walking and mental health (Table 1). Measures or disorders of cognitive dysfunction were considered neurological and thus outside the scope of this review. Eating disorders were included as they significantly impair physical health or psychosocial functioning. Health-related quality-of-life was excluded as it was considered to incorporate physical, social, emotional and mental factors. 
Table 1. Definitions of the mental health outcomes included within the review: the outcomes were informed by Kelly et al. (2018) [8].

\begin{tabular}{|c|c|}
\hline Outcome & Description \\
\hline Depression & $\begin{array}{l}\text { Depression is a mood disorder with prolonged periods of low mood and a lack of interest and/or pleasure } \\
\text { in normal activities most of the time. This includes major depressive disorder [19]. }\end{array}$ \\
\hline Anxiety & $\begin{array}{l}\text { Anxiety is characterised by uncomfortable or upsetting thoughts and is usually accompanied by agitation, } \\
\text { feelings of tension and activation of the autonomic nervous system. It is important to note the distinction } \\
\text { between transient anxiety symptoms (state anxiety), persistent symptoms (trait anxiety) and anxiety } \\
\text { disorders: a collection of disabling conditions characterised by excessive, chronic anxiety. Examples of } \\
\text { anxiety disorders are specific phobias, social phobia, generalised anxiety disorder, panic disorder, } \\
\text { obsessive-compulsive disorder and post-traumatic stress disorder [20]. }\end{array}$ \\
\hline Self-efficacy & $\begin{array}{l}\text { Self-efficacy is a situation-specific form of self-confidence. Self-efficacy beliefs influence how people think, } \\
\text { feel, motivate themselves and act [21]. }\end{array}$ \\
\hline Psychological stress & $\begin{array}{l}\text { Psychological stress or distress can be defined as the unique discomforting, emotional state experienced } \\
\text { by an individual in response to a specific stressor or demand that results in harm, either temporary or } \\
\text { permanent, to that person [22]. }\end{array}$ \\
\hline Eating pathology & $\begin{array}{l}\text { Eating pathology or disorder can be described as persistent disturbance of eating behaviours or } \\
\text { behaviours intended to control weight, which significantly impairs physical health or psychosocial } \\
\text { functioning. This disturbance should not be secondary to any recognised general medical disorder, } \\
\text { e.g., hypothalamic tumour. This definition includes anorexia nervosa and bulimia nervosa [23]. }\end{array}$ \\
\hline Self-esteem & $\begin{array}{l}\text { Self-esteem is the feelings of value and worth that a person has for oneself. It contributes to overall } \\
\text { self-concept as a construct of mental health [24]. }\end{array}$ \\
\hline Addiction & $\begin{array}{l}\text { Addiction designates a process whereby a behaviour that can function both to produce pleasure and to } \\
\text { provide escape from internal discomfort is employed in a pattern characterized by (1) recurrent failure to } \\
\text { control the behaviour (powerlessness) and (2) continuation of the behaviour despite significant negative } \\
\text { consequences (unmanageability) [25]. }\end{array}$ \\
\hline Psychological well-being & $\begin{array}{l}\text { Psychological well-being links with autonomy, environmental mastery, personal growth, positive relations } \\
\text { with others, purpose in life and self-acceptance. This is often referred to as eudemonic well-being [26]. }\end{array}$ \\
\hline Self-concept & $\begin{array}{l}\text { Self-concept is the organisation of qualities that the individual attributes to themself, which in turn guides } \\
\text { or influences the behaviour of that individual [27]. }\end{array}$ \\
\hline Mood & $\begin{array}{l}\text { Mood is a transient state of a set of feelings, usually involving more than one emotion. Seen as a conscious } \\
\text { summative recognition of feelings that can vary in intensity and duration [28]. }\end{array}$ \\
\hline
\end{tabular}

\subsection{Identify Relevant Studies}

Studies were included based on the following criteria:

- Any geographical location

- All years between 1970 and 2019

- Quantitative effects of running on predetermined mental health outcomes

$\bigcirc \quad$ Preventive effects (negative)

$0 \quad$ Health promotion effects (positive)

$\bigcirc \quad$ Intervention effects

- $\quad$ Any age group or sex

- Human studies

- Designs including primary research (cross-sectional, longitudinal, interventions and natural experiments with pre-post measures with or without non-running comparisons)

- Studies that mentioned walking as well as running were included because it is not possible to differentiate walkers from runners in events such as Parkrun.

Studies were excluded based on the following criteria:

- Specialist groups including elite, professional or competitive athletes.

- General physical or aerobic activity, rather than exclusively running

- Qualitative and ethnographic designs

- Systematic and scoping reviews (individual studies from identified reviews were included if relevant) 
- Editorials, opinion pieces, magazine/newspaper articles, case reports and papers without primary data

- Focus on secondary mental health within clinical groups with specific physical or mental conditions that is not the condition being treated with running (e.g., effects on depression in patients with cancer)

- Evidence types including guidelines, unpublished and ongoing trials, annual reports, dissertations and conference proceedings

- Animal studies

- Unavailable in English

- Running intervention was part of a wider study where differentiating the individual effect of running was not possible (e.g., combined with weight management).

- Conference abstracts that were not published as full articles

Search Strategy and Databases

Databases searched were Ovid (Medline), Ovid (Embase), ProQuest and SportDiscus. Databases were searched for titles and abstracts that included at least one running term with one mental health outcome term. Appropriate truncation symbols were used to account for search term variations. Common running terms were combined. Search terms and the full search syntax can be found in Appendix B. Searches were conducted for papers published up to August 2019.

\subsection{Study Selection}

All identified records were uploaded to Covidence (https://www.covidence.org), and duplicates were automatically removed. Titles and abstracts were screened, with $20 \%$ cross-checked early in the process to assess agreement between authors. Full texts were reviewed by 2 authors.

\subsection{Charting the Data}

Data extraction was completed by the lead author (F.O.) with $5 \%$ double screened by a second author (J.R.). The data extraction form was pilot tested with the first 20 studies and informed the following standardised extraction agreed upon by all authors:

(1) Author(s), year of publication and geographical location of study

(2) Mental health conditions examined

(3) Sample size and population details

(4) Study design

(5) Measures used to quantify any change in mental health outcome(s)

(6) Running dose (if applicable) and compliance (if applicable)

(7) Whether running was beneficial and the main findings

In studies that used "Profile of Mood States" (POMS) as a measurement of mood state, total mood disturbance was used in this review if reported by the authors. If the authors only reported one/some of the POMS subdimensions, these data were extracted instead.

\subsection{Collating, Summarising and Reporting Results}

Included studies were organized into 3 categories: cross-sectional studies, acute (single, double or triple) bouts of running, and long-term running interventions. For each of these 3 categories, the results were presented in two ways: (a) a descriptive numerical analysis to highlight the prevailing domains of research regarding geographical location, mental health outcomes and research methods and (b) a narrative summary of the key findings. 


\section{Results}

\subsection{Included Studies}

From initial searches, 29,851 papers were identified. Following removal of duplicates, 16,401 were screened at the title and abstract levels and 273 papers were retained for full-text assessments. Ultimately, 116 papers met the inclusion criteria for this review. Figure 1 displays the PRISMA study flowchart. The results are presented in the following 3 categories: cross-sectional studies, acute bouts of running and longer-term interventions.

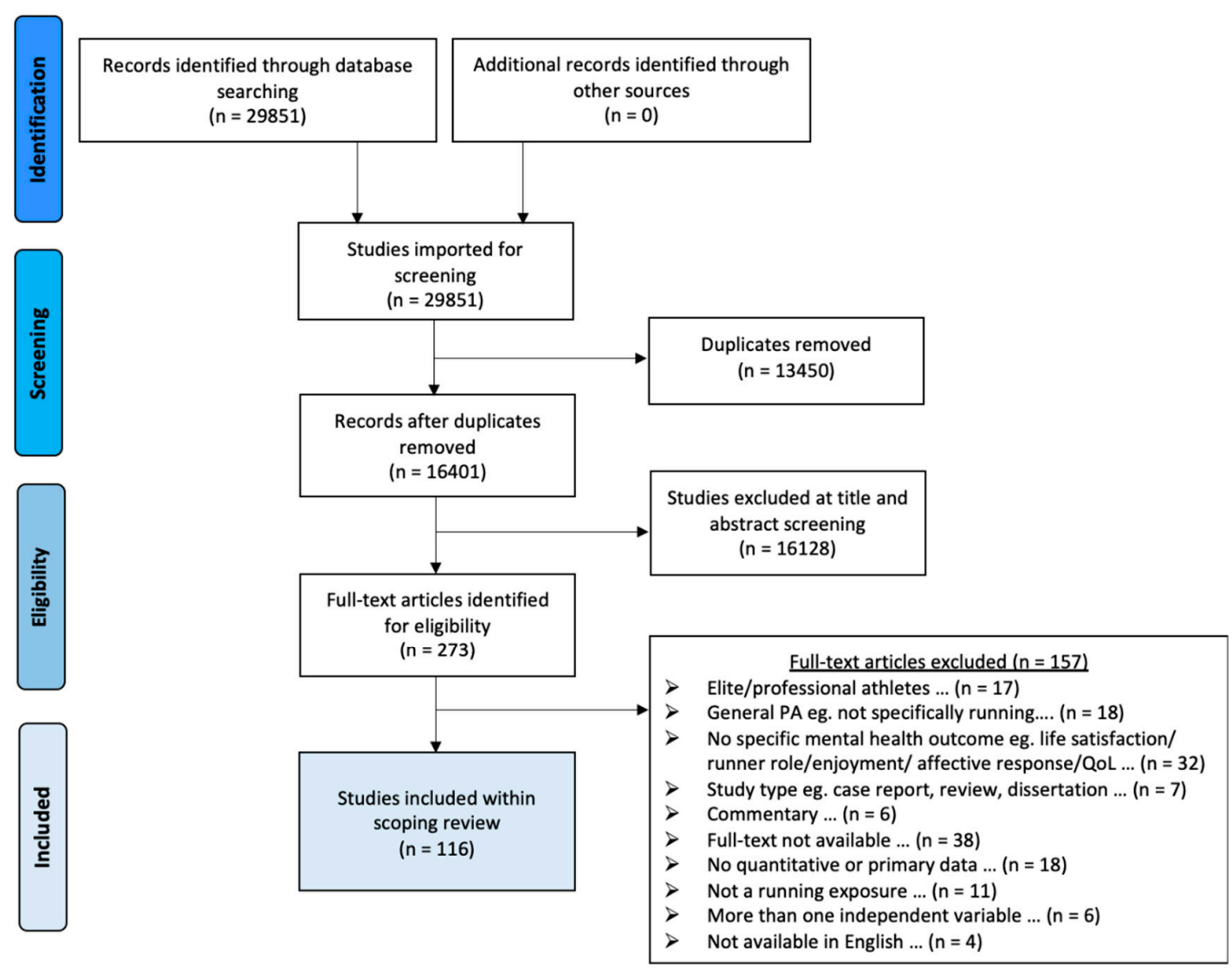

Figure 1. Preferred Reporting Items for Systematic Reviews and Meta-Analyses (PRISMA) depicting the identification, screening, eligibility and inclusions of texts within the scoping review.

\subsection{Category 1: Cross-Sectional Studies}

Forty-seven studies utilised cross-sectional designs (with and without non-running comparison groups) (Table 2) [29-75]. These studies assessed exposure to regular running by questionnaire. Narrative description of findings of the 47 cross-sectional studies are included within Table S1 within the supplementary material. 
Table 2. Summary of data extraction from the 47 cross-sectional studies.

\begin{tabular}{|c|c|c|c|c|c|c|c|}
\hline Author & Year & Country & Design & Population & $\begin{array}{c}\text { Mental Health Outcome } \\
\text { (Measurement) }\end{array}$ & Study Aim & Main Findings \\
\hline Wilson et al. [29] & (1980) & Canada & Cross-sectional & $\begin{array}{l}n=30 \text {, all male; age range 20-45; } \\
10 \text { marathoners, } 10 \text { regular } \\
\text { joggers and } 10 \text { non-exercisers }\end{array}$ & Mood (Profile of Mood States) & $\begin{array}{l}\text { Comparing mood states of } \\
\text { marathon runners, regular } \\
\text { joggers and non-exercisers }\end{array}$ &  \\
\hline Joesting [30] & (1981) & USA & $\begin{array}{c}\text { Controlled } \\
\text { cross-sectional }\end{array}$ & $\begin{array}{c}n=100 \text { runners; } 79 \text { males, } \\
\text { mean age } 18.36 ; 21 \text { females, } \\
\text { mean age } 16.53\end{array}$ & $\begin{array}{l}\text { Depression (Depression Adjective } \\
\text { Checklist) }\end{array}$ & $\begin{array}{l}\text { Investigating the relationship } \\
\text { between running and depression }\end{array}$ & $\begin{array}{l}\text { Significantly }(p<0.01) \text { decreased depression in males and female runners compared to } \\
\text { Lubin's data for nonpsychiatric patients: male and female runners mean depression scores } \\
\text { were } 4.59 \text { and } 4.33 \text {, respectively, while the normative nonpsychiatric sample means were } 8.02 \\
\text { and } 7.32 \text {, respectively. }\end{array}$ \\
\hline $\begin{array}{l}\text { Jorgenson et al. } \\
{[31]}\end{array}$ & (1981) & USA & Cross-sectional & $\begin{array}{l}n=454 \text { regular runners; } \\
390 \text { males and } 64 \text { females; } \\
\text { majority aged } 30-39\end{array}$ & $\begin{array}{l}\text { Emotional well-being (structured } \\
\text { questionnaire consisting of } 55 \text { items } \\
\text { designed by the author) }\end{array}$ & $\begin{array}{l}\text { Investigating the relationship } \\
\text { between emotional well-being } \\
\text { and running }\end{array}$ & $\begin{array}{l}\text { Of the runners, } 92.3 \%(n=419) \text { indicated an increase in emotional well-being }(p<0.01) \text { but } \\
\text { no report on the scale of improvement. Age and emotional well-being were significantly } \\
\text { correlated (gamma value }=0.42, p<0.001) \text {, with the older runner having the greater } \\
\text { perception of enotional well-being resulting from running. There was a significant inverse } \\
\text { relationship between average hours per week running and emotional well-being (gamma } \\
\text { value }=-0.43, p<0.001) .\end{array}$ \\
\hline Valliant et al. [32] & (1981) & Canada & Cross-sectional & $\begin{array}{l}n=68 \text { male runners; } 30 \text { marathon } \\
\text { runners, mean age } 34.4 ; \\
38 \text { recreational runners, } \\
\text { mean age } 20.6\end{array}$ & $\begin{array}{l}\text { Self-sufficiency and personality profiles } \\
\text { (a 1-h "Sixteen Personalilty Factor } \\
\text { Questionnaire") }\end{array}$ & $\begin{array}{l}\text { Comparing self-sufficiency and } \\
\text { personality profiles in marathon } \\
\text { runners vs. recreational joggers }\end{array}$ & 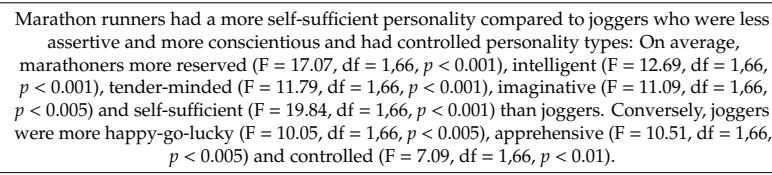 \\
\hline Francis et al. [33] & (1982) & USA & Cross-sectional & $\begin{array}{l}n=44 \text { male participants; mean } \\
\text { age } 32 ; \text { non-running controls who } \\
\text { ran } 0 \text { miles weekly }(n=16), \\
20 \text { miles }(n=10), 30-40 \text { miles } \\
(n=8) \text { and } 50-60 \text { miles }(n=10)\end{array}$ & $\begin{array}{l}\text { Anxiety, depression and hostility } \\
\text { (State-Trait Anxiety Inventory and the } \\
\text { Multiple Affect Adjective Check List) }\end{array}$ & $\begin{array}{l}\text { Comparing anxiety, depression } \\
\text { and hostility in various groups of } \\
\text { runners vs. sedentary controls }\end{array}$ & $\begin{array}{c}\text { Compared to sedentary controls, runners had lower anxiety }(4.2 \text { vs. } 7.2, p<0.01) \text {, } \\
\text { depression }(8.6 \text { vs. } 12.3, p<0.01) \text { and hostility }(4.8 \text { vs. } 6.8, p<0.01) .\end{array}$ \\
\hline Hailey et al. [34] & (1982) & USA & Cross-sectional & $\begin{array}{l}n=60 \text { male runners; aged 13-60; } \\
\text { Those who ran for less than } 1 \\
\text { year }(n=12), \text { those who ran for } \\
1-4 \text { years }(n=32) \text { and those who } \\
\text { ran for over } 4 \text { years }(n=16)\end{array}$ & $\begin{array}{l}\text { Negative addiction (Negative } \\
\text { addiction scale) }\end{array}$ & $\begin{array}{l}\text { Investigating the relationship } \\
\text { between running and negative } \\
\text { addiction }\end{array}$ & 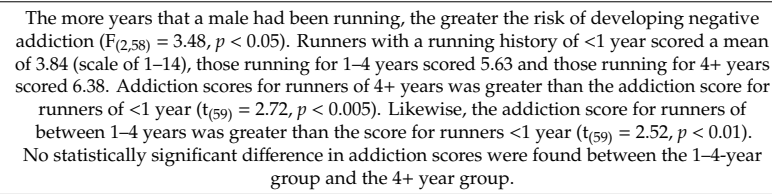 \\
\hline Callen [35] & (1983) & USA & Cross-sectional & $\begin{array}{l}n=424 \text { non-professional runners } \\
\text { who ran on average more than } \\
28.8 \text { miles per week; } 303 \text { males } \\
\text { and } 121 \text { females; mean age } 34\end{array}$ & $\begin{array}{l}\text { Mental and emotional aspects (a } \\
\text { questionnaire designed by the author) }\end{array}$ & $\begin{array}{l}\text { Investigating mental and } \\
\text { emotional aspects associated with } \\
\text { long-distance running in } \\
\text { non-professional runners, } \\
\text { including depression, tension, } \\
\text { mood, happiness, self-confidence } \\
\text { and self-image } \\
\end{array}$ & 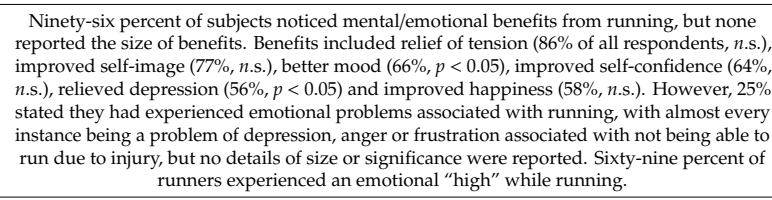 \\
\hline Galle et al. [36] & (1983) & USA & $\begin{array}{l}\text { Controlled } \\
\text { cross-sectional }\end{array}$ & $\begin{array}{l}n=391 \text { female subjects; aged } 15 \\
\text { to } 50 \text {; runners }(n=102) \text {, infertility } \\
\text { patients }(n=103), \text { fertile subjects } \\
(n=139) \text { and Clomid study } \\
\text { patients whose only infertility } \\
\text { abnormality was ovulation } \\
\text { dysfunction }(n=47)\end{array}$ & $\begin{array}{l}\text { Anxiety and depression (Hopkins } \\
\text { Symptom Checklist-90) }\end{array}$ & $\begin{array}{l}\text { Comparing psychologic profiles } \\
\text { including anxiety and depression } \\
\text { in runners, infertility patients, } \\
\text { fertile subjects and Clomid study } \\
\text { patients whose only infertility } \\
\text { abnormality was ovulation } \\
\text { dysfunction }\end{array}$ & 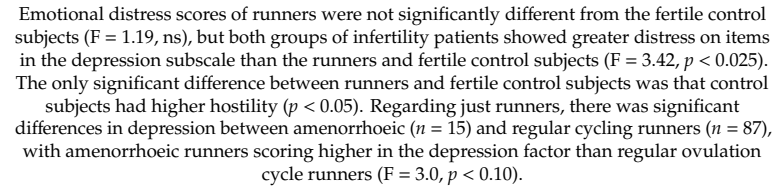 \\
\hline
\end{tabular}


Table 2. Cont.

\begin{tabular}{|c|c|c|c|c|c|c|c|}
\hline Author & Year & Country & Design & Population & $\begin{array}{c}\text { Mental Health Outcome } \\
\text { (Measurement) }\end{array}$ & Study Aim & Main Findings \\
\hline Lobstein et al. [37] & (1983) & USA & $\begin{array}{c}\text { Pre-post controlled } \\
\text { between subject } \\
\text { design }\end{array}$ & $\begin{array}{l}n=22 \text { medically healthy men; } \\
11 \text { physically active men and } 11 \\
\text { sedentary men; aged } 40-60\end{array}$ & $\begin{array}{l}\text { Depression (Minnesota Multiphasic } \\
\text { Personality Inventory) }\end{array}$ & $\begin{array}{l}\text { Assessing the impact of a } \\
\text { treadmill run with increasing } \\
\text { gradient on depression }\end{array}$ & $\begin{array}{l}\text { Sedentary men were significantly more depressed than men who ran (mean }=61.36 \text { vs. } 50.73 \text {, } \\
\text { respectively, } p<0.01 \text { ), but both groups were within clinical limits for normal, mentally } \\
\text { healthy, middle aged men. }\end{array}$ \\
\hline Rudy et al. [38] & (1983) & USA & Cross-sectional & $\begin{array}{c}n=319 \text { female regular runners; } \\
\text { aged between } 16 \text { and } 60\end{array}$ & $\begin{array}{l}\text { Anxiety and self-esteem (Rosenberg } \\
\text { Self-esteem Scale and Zuckerman's } \\
\text { Anxiety Adjective Checklist) }\end{array}$ & $\begin{array}{l}\text { Investigating how levels of } \\
\text { anxiety and self-esteem related to } \\
\text { intensity of jogging }\end{array}$ &  \\
\hline Goldfarb et al. [39] & (1984) & USA & Cross-sectional & $\begin{array}{l}n=200 \text { distance runners; } \\
136 \text { males and } 64 \text { females }\end{array}$ & $\begin{array}{l}\text { Anorexia nervosa traits (Goldfarb Fear } \\
\text { of Fat scale and Activity Vector } \\
\text { Analysis) }\end{array}$ & $\begin{array}{l}\text { Investigating anorexia nervosa } \\
\text { traits within distance runners }\end{array}$ & 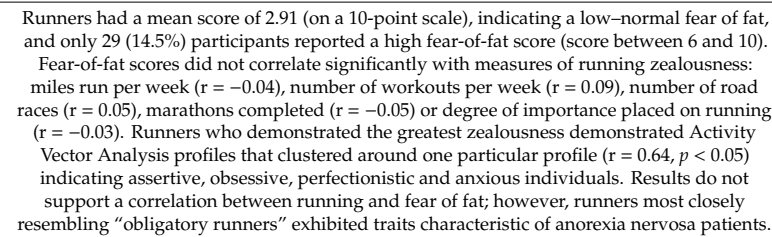 \\
\hline -Guyot et al. [40] & (1984) & USA & $\begin{array}{c}\text { Controlled } \\
\text { cross-sectional }\end{array}$ & $\begin{array}{l}n=126 \text { participants; } 64 \text { runners } \\
(44 \text { males and } 20 \text { females) vs. } 62 \\
\text { non-runners } 37 \text { males and } \\
25 \text { females) }\end{array}$ & Death anxiety (Death Concern Scale) & $\begin{array}{l}\text { Comparing death anxiety in } \\
\text { runners vs. non-runners }\end{array}$ & $\begin{array}{l}\text { Runners experienced more death thoughts }\left(\mathrm{F}_{(1,122)}=4.49, p<0.05\right) \text { but less death anxiety } \\
\qquad\left(\mathrm{F}_{(1,122)}=6.35, p<0.05\right) \text { than non-runners. }\end{array}$ \\
\hline Rape [41] & (1987) & USA & $\begin{array}{c}\text { Controlled } \\
\text { cross-sectional }\end{array}$ & $\begin{array}{l}n=42 \text { male participants; aged } \\
18-25 ; 21 \text { runners vs. } 21 \\
\text { non-exercisers }\end{array}$ & $\begin{array}{l}\text { Depression (Beck Depression } \\
\text { Inventory) }\end{array}$ & $\begin{array}{l}\text { Comparing depression scores in } \\
\text { runners vs. non-exercisers }\end{array}$ & $\begin{array}{l}\text { Runners were significantly less depressed }(\mathrm{M}=4.38, \mathrm{SD}=3.88) \text { than the non-exercisers } \\
(\mathrm{M}=9.55, \mathrm{SD}=5.40)\left(\mathrm{t}_{40}=3.55, p<0.011\right) \text {. Overall results suggest that running } \\
\text { reduces depression. }\end{array}$ \\
\hline Weight et al. [42] & (1987) & South Africa & $\begin{array}{l}\text { Controlled } \\
\text { cross-sectional }\end{array}$ & $\begin{array}{c}n=135 \text { female participants } \\
\text { consisting of marathon runners } \\
(n=85) \text { vs. cross country runners } \\
(n=25) \text { vs. non-running controls } \\
(n=25) \text {; aged } 18-56\end{array}$ & $\begin{array}{l}\text { Eating attitudes and disorders (Eating } \\
\text { Attitudes Test and the Eating Disorder } \\
\text { Inventory) }\end{array}$ & $\begin{array}{l}\text { Comparing eating attitudes and } \\
\text { disorders in marathon runners vs. } \\
\text { cross country runners vs. } \\
\text { non-running controls. }\end{array}$ & $\begin{array}{l}\text { No significant differences were found between groups on any of the Eating Attitudes Test } \\
\text { scores (mean scores }=8.4,14.3 \text { and } 11.8) \text {. Eating Disorder Inventory scores also did not follow } \\
\text { a definite pattern (means scores for marathoners, cross country yunners and non-runninig } \\
\text { controls were } 24.8,27,1 \text { and } 32.0, \text { respectively), indicating that abnormal eating attitudes and } \\
\text { the incidence of anorexia was no more common among competitive female runners than } \\
\text { among the general population, with a low incidence of anorexia in the total group ( } 2 \text { out of } \\
135 \text { participants). }\end{array}$ \\
\hline Chan et al. [43] & (1988) & USA & Cross-sectional & $\begin{array}{c}n=60 \text { runners who ran at least } \\
3 \times \text { per week for a minimum of a } \\
\text { year; } 28 \text { males and } 32 \text { females; } \\
\text { prevented runners } n=30 \text { s. } \\
\text { continuing runners } n=30 ; \\
\text { aged } 15-50 \text {. }\end{array}$ & $\begin{array}{l}\text { Depression, self-esteem and mood } \\
\text { (Zung depression Scale, Rosenberg } \\
\text { Self-esteem Scale and Profile of Mood } \\
\text { States) }\end{array}$ & $\begin{array}{l}\text { Comparing depression, } \\
\text { self-esteem and mood in } \\
\text { prevented runners vs. continuing } \\
\text { runners }\end{array}$ & 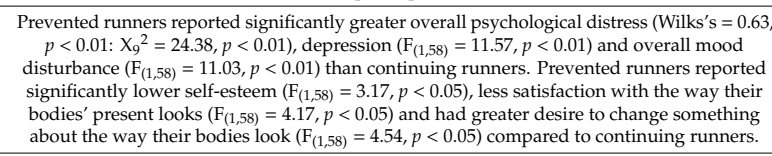 \\
\hline Frazier [44] & (1988) & USA & $\begin{array}{c}\text { Post only, } \\
\text { nonrandomised } \\
\text { long-term } \\
\text { observational } \\
\text { study } \\
\end{array}$ & $\begin{array}{c}n=86 \text { regular, distance runners } \\
\text { who had all completed a } \\
\text { marathon; } 68 \text { males with mean } \\
\text { age of } 33.7 \text { and } 18 \text { females with a } \\
\text { mean age of } 32.2\end{array}$ & Mood (Profile of Mood States) & $\begin{array}{l}\text { Investigating the relationship } \\
\text { between running and mood in } \\
\text { regular distance runners }\end{array}$ & 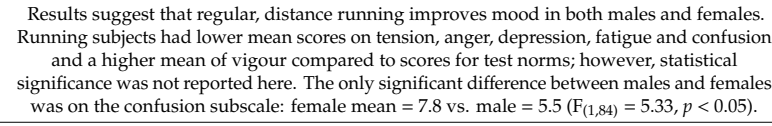 \\
\hline $\begin{array}{l}\text { Lobstein, Ismail et } \\
\text { al. [45] }\end{array}$ & (1989) & USA & $\begin{array}{c}\text { Controlled } \\
\text { cross-sectional }\end{array}$ & $\begin{array}{l}n=36 \text { male participants; aged } \\
40-60 \text {; runners }(n=21) \text { vs. } \\
\text { sedentary controls }(n=15)\end{array}$ & $\begin{array}{l}\text { Anxiety and depression (Minnesota } \\
\text { Multiphasic Personality Inventory and } \\
\text { Eysenck Personality Inventory) }\end{array}$ & $\begin{array}{l}\text { Comparing anxiety and } \\
\text { depression levels in runners vs. } \\
\text { sedentary controls }\end{array}$ & $\begin{array}{l}\text { Overall, running reduced anxiety (mean }=48.95 \mathrm{vs.} 61.48 \text { respectively, } p<0.05 \text {, standardised } \\
\text { canonical coefficient }=-1.07 \text { ) and depression (mean }=50.76 \text { vs. } 57.93 \text {, respectively, } p<0.05, \\
\text { standardised canonical coefficient }=0.00 \text { ) compared to being sedentary. }\end{array}$ \\
\hline $\begin{array}{c}\text { Lobstein, } \\
\text { Rasmussen et al. } \\
{[46]}\end{array}$ & (1989) & USA & $\begin{array}{c}\text { Controlled } \\
\text { cross-sectional }\end{array}$ & $\begin{array}{l}n=20 \text { psychologically normal, } \\
\text { medically healthy men; aged } \\
40-60 \text {; physically active joggers } \\
(n=10) \text { vs. sedentary }(n=10)\end{array}$ & $\begin{array}{l}\text { Depression and stress (Eysenck } \\
\text { Personality Inventory and Minnesota } \\
\text { Multiphasic Personality Inventory) }\end{array}$ & $\begin{array}{l}\text { Comparing depression and stress } \\
\text { in sedentary men to physically } \\
\text { active joggers }\end{array}$ & $\begin{array}{l}\text { The findings suggest that regular jogging increases emotional stability ( } \mathrm{t}=-2.84, p<0.01 \text { ) and } \\
\text { decreases subjective depression with MMPI subscales of depression and Wiggins depression } \\
\text { both being significantly lower in the joggers }(t=3.70, p<0.01 ; t=2.40, p<0.05 \text {; respectively). }\end{array}$ \\
\hline
\end{tabular}


Table 2. Cont

\begin{tabular}{|c|c|c|c|c|c|c|c|}
\hline Author & Year & Country & Design & Population & $\begin{array}{c}\text { Mental Health Outcome } \\
\text { (Measurement) }\end{array}$ & Study Aim & Main Findings \\
\hline Nouri et al. [47] & (1989) & USA & Cross-sectional & $\begin{array}{l}n=100 \text { male participants; aged } \\
18-62 \text {; } 1 \text { on-exercisisers }(n=28), \\
\text { drop-out joggers }(n=21), \\
\text { beginning joggers }(n=15), \\
\text { intermediate joggers }(n=16) \text { and } \\
20 \text { advanced joggers }(n=20) \\
\end{array}$ & $\begin{array}{l}\text { Anxiety and addiction/commitment } \\
\text { (State-Trait Anxiety Inventory, } \\
\text { Commitment to Running Scale, } \\
\text { and The Buss-Dutkee Inventory } \\
\text { measuring hostility and aggression) }\end{array}$ & $\begin{array}{l}\text { Investigating the relationship } \\
\text { between various levels of jogging } \\
\text { vs. non-exercising on anciety and } \\
\text { addiction/commitment }\end{array}$ & $\begin{array}{l}\text { Running reduced anxiety levels compared to physical inactivity }\left(\mathrm{F}_{4,49}=4.43, p<0.01\right) \text {, } \\
\text { with advanced joggers scoring significantly lower on trait anxiety than beginner and } \\
\text { intermediate joggers (1.42 vs. } 1.77 \text { vs. } 1.69, \text { respectively, } p<0.01) \text { and commitment to running } \\
\text { significantly higher for the joggers than the non-exercisers }\left(\mathrm{F}_{(4,89)}=14.30, p<0.01\right) \text {. }\end{array}$ \\
\hline Chan et al. [48] & (1990) & Hong Kong & Cross-sectional & $\begin{array}{c}n=44 \text { male runners of track clubs } \\
\text { who ran a mean of } 57.2 \mathrm{~km} \text { per } \\
\text { week; mean age } 27.8\end{array}$ & $\begin{array}{l}\text { Depression, stress, tension and } \\
\text { personality profiles (Chineseversion of } \\
\text { the Personality Research Form) }\end{array}$ & $\begin{array}{l}\text { Investigating the relationship } \\
\text { between running and depression, } \\
\text { stress, tension and personality } \\
\text { profiles }\end{array}$ & 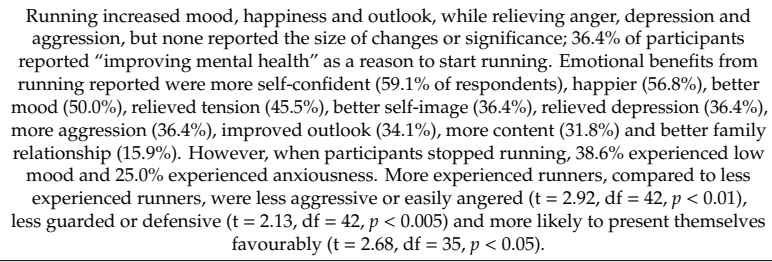 \\
\hline$\underset{[49]}{\text { Chapman et al. }}$ & (1990) & USA & Cross-sectional & $\begin{array}{c}n=47 \text { runners; } 32 \text { males aged } \\
34-57 \text { and } 15 \text { females aged } 35 \\
\text { to } 59\end{array}$ & $\begin{array}{l}\text { Running addiction, psychological } \\
\text { characteristics and running (Running } \\
\text { Addiction Scale, Commitment to } \\
\text { Running Scale, Symptom Checklist } \\
\text { (SCL-90-R) and Levenson's Locus of } \\
\text { Control Scale) }\end{array}$ & $\begin{array}{l}\text { Investigating the relationship } \\
\text { between running addiction, } \\
\text { psychological characteristics } \\
\text { and running }\end{array}$ & 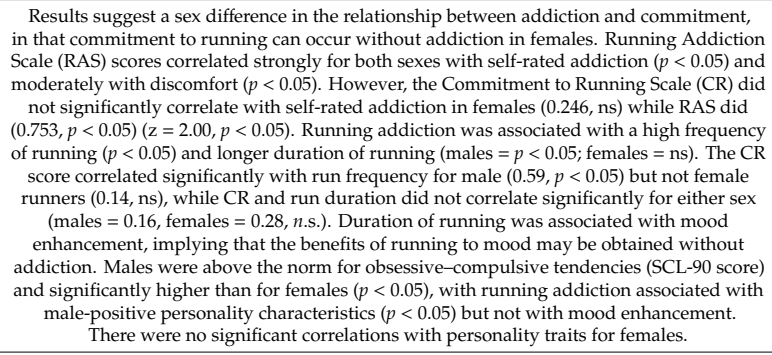 \\
\hline Guyot [50] & (1991) & USA & Cross-sectional & $\begin{array}{l}n=370 \text { regular long-distance } \\
\text { runners; } 289 \text { males, mean age } 38 ; \\
81 \text { females, mean age } 35\end{array}$ & $\begin{array}{l}\text { Addiction and death anxiety (Dickstein } \\
\text { Death Concern Scale and } \\
\text { author-created questionnaires for pain } \\
\text { running, running motives, risk taking } \\
\text { and medical symptoms) } \\
\end{array}$ & $\begin{array}{l}\text { Investigating the relationship } \\
\text { between addiction and death } \\
\text { anxiety between pain runners } \\
\text { and non-pain runners }\end{array}$ & 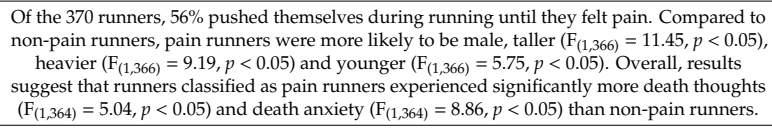 \\
\hline Maresh et al. [51] & (1991) & USA & Cross-sectional & $\begin{array}{c}n=29 \text { male distance runners; } \\
\text { mean age } 40.1\end{array}$ & $\begin{array}{l}\text { Psychological characteristics including } \\
\text { anxiety, depression and stress } \\
\text { (Myers-Briggs Type Indicator Form } \\
\text { and Multidimensional } \\
\text { Anger-Inventory) }\end{array}$ & $\begin{array}{l}\text { Investigating psychological } \\
\text { characteristics including anxiety, } \\
\text { depression and stress in } \\
\text { distance runners }\end{array}$ & 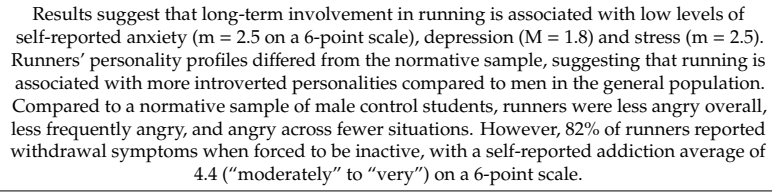 \\
\hline Gleaves et al. [52] & (1992) & USA & $\begin{array}{c}\text { Controlled } \\
\text { cross-sectional }\end{array}$ & $\begin{array}{l}n=60 \text { female participants; } \\
\text { runners }(n=20) \text {, bulimia patients } \\
(n=20 \text { and a non-exercising, } \\
\text { non-dieting control group }(n=20)\end{array}$ & $\begin{array}{l}\text { Depression, body image and bulimia } \\
\text { nervosa symptomology (Beck's } \\
\text { Depression Inventory, Body Image } \\
\text { Assessment Procedure, subscales from } \\
\text { the Eating Disorder Inventory, } \\
\text { Automatic thoughts Questionnaire and } \\
\text { dieting/weight loss questionnaire) }\end{array}$ & $\begin{array}{l}\text { Comparing depression, body } \\
\text { image disturbance and bulimia } \\
\text { nervosa symptomology in } \\
\text { runners, bulimia patients and a } \\
\text { non-exercising, non-dieting } \\
\text { control group }\end{array}$ & 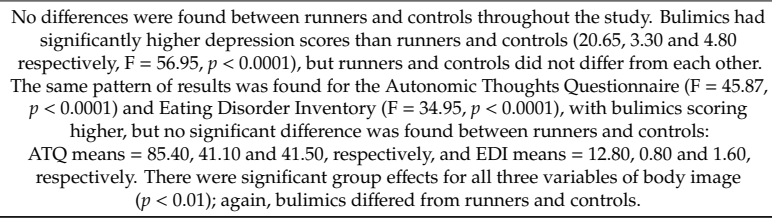 \\
\hline
\end{tabular}


Table 2. Cont

\begin{tabular}{|c|c|c|c|c|c|c|c|}
\hline Author & Year & Country & Design & Population & $\begin{array}{c}\text { Mental Health Outcome } \\
\text { (Measurement) }\end{array}$ & Study Aim & Main Findings \\
\hline Coen et al. [53] & (1993) & USA & Cross-sectional & $\begin{array}{l}n=142 \text { male marathon runners; } \\
\text { mean age } 44.07 \text {; obligatory } \\
\text { runners }(n=65) \text { vs. } \\
\text { non-obligatory runners }(n=77)\end{array}$ & $\begin{array}{l}\text { Anxiety, anorexia and self-identity } \\
\text { (Obligatory Exercise Questionnaire, } \\
\text { State-Trait Personality Inventory and } \\
\text { The Ego Identity Scale) }\end{array}$ & $\begin{array}{l}\text { Investigating the relationship } \\
\text { between obligatory running vs. } \\
\text { non-obligatory running on } \\
\text { anxiety, anorexia and self-identity }\end{array}$ & 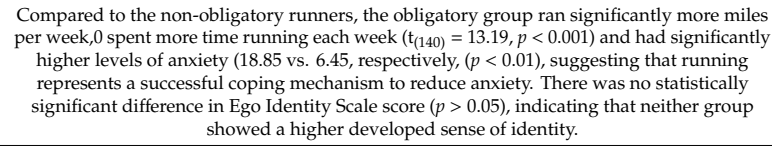 \\
\hline Furst et al. [54] & (1993) & USA & $\begin{array}{l}\text { Controlled } \\
\text { cross-sectional }\end{array}$ & $\begin{array}{c}n=188 \text { participants, with } n=98 \\
\text { runners: } 7 \text { males and } 26 \text { females } \\
\text { vs. } n=90 \text { gym exercisers: } 60 \\
\text { males and } 30 \text { females; majority } \\
\text { aged } 20-29\end{array}$ & $\begin{array}{l}\text { Negative addiction (Negative } \\
\text { Addiction Scale) }\end{array}$ & $\begin{array}{l}\text { Comparing negative addiction in } \\
\text { runners vs. gym exercisers }\end{array}$ & $\begin{array}{l}\text { A significant association was found between years of participation in physical activity and } \\
\text { addiction scores }(F(5,182)=6.39, p<0.01) \text { regardless of the type of activity, with no significant } \\
\text { differences in addiction scores between runners and gym exercisers. }\end{array}$ \\
\hline Masters et al. [55] & (1993) & USA & Cross-sectional & $\begin{array}{l}n=712 \text { participants in a } \\
\text { marathon; } 601 \text { males and } 111 \\
\text { females; aged 16-79 }\end{array}$ & $\begin{array}{l}\text { Self-esteem and psychological coping } \\
\text { of runners (Motivation of Marathoners } \\
\text { Scales, Sport Orientation } \\
\text { Questionnaire, Marlowe-Crowne } \\
\text { Social Desirability Scale, -Attentional } \\
\text { Focusing Questionnaire, and } 3 \text { body } \\
\text { satisfaction and composition questions) }\end{array}$ & $\begin{array}{l}\text { Investigating self-esteem and } \\
\text { psychological coping of marathon } \\
\text { runners }\end{array}$ & 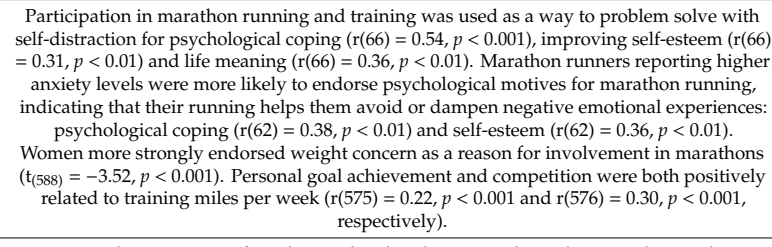 \\
\hline Pierce et al. [56] & (1993) & USA & Cross-sectional & $\begin{array}{c}n=89 \text { male runners; } n=33 \\
\text { non-competitive runners vs. } \\
n=24 \text { 5-km runners vs. } n=32 \\
\text { marathoner runners }\end{array}$ & $\begin{array}{l}\text { Exercise dependence (negative } \\
\text { addiction scale) }\end{array}$ & $\begin{array}{l}\text { Comparing exercise dependence } \\
\text { in recreational (non-competitive) } \\
\text { runners sv. } 5 \text {-km runners vs. } \\
\text { marathoner runners }\end{array}$ & $\begin{array}{l}\text { Training mileage was significantly correlated with exercise dependence, with marathoners } \\
\text { showing significantly higher }(p<0.05) \text { mean exercise dependence scores }(3.78) \text { compared to } \\
5 \mathrm{~K}(2.9) \text { and recreational runners }(2.16) \text {. There was no significant tifference in exercise } \\
\text { dependence scores found between recreational and } 5 \mathrm{~K} \text { runners. }\end{array}$ \\
\hline Klock et al. [57] & (1995) & USA & $\begin{array}{c}\text { Controlled } \\
\text { cross-sectional }\end{array}$ & $\begin{array}{l}n=22 \text { females who were not } \\
\text { currently pregnant or taking oral } \\
\text { contraceptives; amenororhoeic } \\
\text { runners }(n=7, \text { mean age } 28.0), \\
\text { eumenorrtheic runners }(n=9, \\
\text { mean age } 32.1 \text { and eumenorrheic } \\
\text { sedentary women as controls } \\
(n=6, \text { mean age }=27.5)\end{array}$ & $\begin{array}{l}\text { Depression, anorexia nervosa, } \\
\text { exceessive exercise and eating disorder } \\
\text { (The modified Body Image } \\
\text { Questionnaire, the Beck Depression } \\
\text { Inventory, the Symptom Checklist-90 } \\
\text { and the Eating Disorders Inventory) }\end{array}$ & $\begin{array}{l}\text { Comparing depression, anorexia } \\
\text { nervosa, excessive exercise and } \\
\text { eating disorders in amenorrhoeic } \\
\text { runners, eumenorrreicic runners } \\
\text { and eumenorrheic sedentary } \\
\text { women as controls }\end{array}$ & 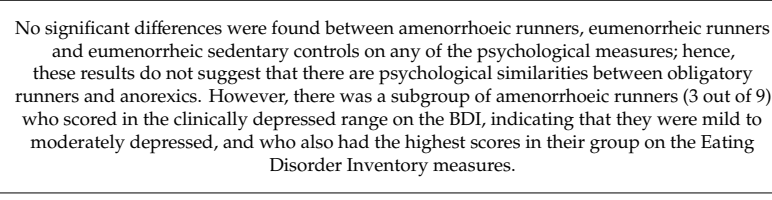 \\
\hline $\begin{array}{c}\text { Thornton et al. } \\
\text { [58] }\end{array}$ & (1995) & UK & Cross-sectional & $\begin{array}{l}n=40 \text { long-standing, habitual } \\
\text { male runners who ran on average } \\
4 \text { times per week with a weekly } \\
\text { mileage of } 42.5 \text { miles; } \\
\text { mean age } 38\end{array}$ & $\begin{array}{l}\text { Addiction (Rudy and Estok Running } \\
\text { Addiction Scale, the Hailey and Bailey } \\
\text { Running Addiction Scale, and the } \\
\text { Personal Incentives for Exercise } \\
\text { questionnaire) }\end{array}$ & $\begin{array}{l}\text { Investigating a relationship } \\
\text { between habitual running and } \\
\text { addiction }\end{array}$ & 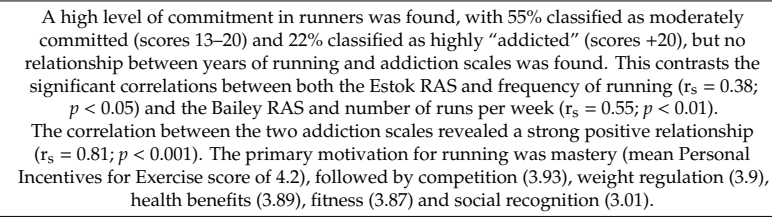 \\
\hline Powers et al. [59] & (1998) & USA & $\begin{array}{l}\text { Controlled } \\
\text { cross-sectional }\end{array}$ & $\begin{array}{l}n=57 \text {; habitual male runners } \\
(n=20) \text {, habitual female runners } \\
(n=20) \text { and female anorexia } \\
\text { nervosa patients }(n=17)\end{array}$ & $\begin{array}{l}\text { Psychological profiles (Minnesota } \\
\text { Multiphasic Personalily Inventory, } \\
\text { Leyton Obsessional Inventory, Obligate } \\
\text { Running Questionnaire, Becks } \\
\text { Depression Inventory and three body } \\
\text { image tests) }\end{array}$ & $\begin{array}{l}\text { Comparing psychological profiles } \\
\text { of habitual male runners, habitual } \\
\text { female runners and female } \\
\text { anorexia nervosa patients }\end{array}$ & 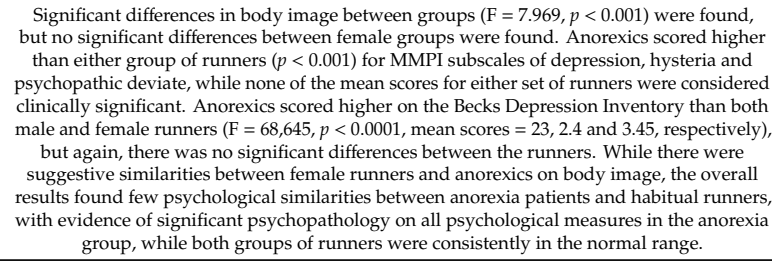 \\
\hline
\end{tabular}


Table 2. Cont

\begin{tabular}{|c|c|c|c|c|c|c|c|}
\hline Author & Year & Country & Design & Population & $\begin{array}{c}\text { Mental Health Outcome } \\
\text { (Measurement) }\end{array}$ & Study Aim & Main Findings \\
\hline Slay et al. [60] & (1998) & USA & Cross-sectional & $\begin{array}{l}n=324 \text { regular runners; } \\
240 \text { males and } 84 \text { females; } \\
84 \text { classified as obligatory } \\
\text { runners: } 63 \text { males and } 2 \text { f females; } \\
\text { ages } 15-71\end{array}$ & $\begin{array}{l}\text { Eating pathology traits (Eat Attitudes } \\
\text { Test, and Obligatory Running and } \\
\text { Motivations for Running } \\
\text { Questionnaire) }\end{array}$ & $\begin{array}{l}\text { Comparing eating pathology } \\
\text { traits between obligatory and } \\
\text { non-obligatory runners }\end{array}$ & 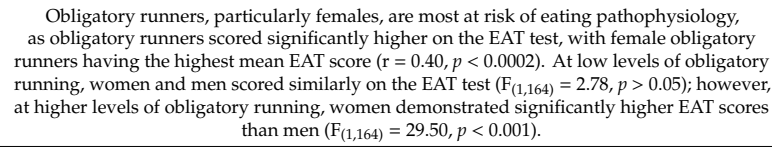 \\
\hline Ryujin et al. [61] & (1999) & USA & $\begin{array}{l}\text { Controlled } \\
\text { cross-sectional }\end{array}$ & $\begin{array}{c}n=55 \text { female participants; } \\
\text { collegiate distance runners } \\
(n=20) \text { vs. non-running } \\
\text { undergraduate student controls } \\
(n=35)\end{array}$ & $\begin{array}{l}\text { Eating disorder symptomology } \\
\text { (Eating Disorders Inventory 2) }\end{array}$ & $\begin{array}{l}\text { Comparing eating disorder } \\
\text { symptomology in collegiate } \\
\text { distance runners to non-running } \\
\text { undergraduate student controls }\end{array}$ & $\begin{array}{l}\text { Distance runners showed no enhanced symptomatology of eating disorders; instead, } \\
\text { female distance runners exhibited fewer symptoms of eating disorders on all subscales of the } \\
\text { Eating Disorder Inventory-2 except Perfectionism: drive for thinness }\left(\mathrm{t}_{10107}=3.34, p<0.005\right), \\
\left.\text { bulimia }\left(\mathrm{t}_{(107)}\right)=2.48, p<0.05\right) \text { and body dissatisfaction }\left(\mathrm{t}_{(107)}=4.23, p<0.001\right) \text {. }\end{array}$ \\
\hline Leedy [62] & (2000) & USA & $\begin{array}{l}\text { Controlled } \\
\text { cross-sectional }\end{array}$ & $\begin{array}{l}n=276 \text { runners with an average } \\
\text { of } 11.5 \text { years of running } \\
\text { experience, } 239 \text { men, mean age } \\
37.9 ; 37 \text { women, mean age } 40.5\end{array}$ & $\begin{array}{l}\text { Depression and anxiety (Diagnostic } \\
\text { and Statistical Manual-IV, and an } \\
\text { author-adapted scale based on the } \\
\text { Running Addiction Scale) }\end{array}$ & $\begin{array}{l}\text { Comparing depression and } \\
\text { anxiety in runners to non-runners }\end{array}$ &  \\
\hline Edwards et al. [63] & (2005) & South Africa & Cross-sectional & $\begin{array}{l}n=277 \text { participants; } 94 \text { males and } \\
183 \text { females; mean age 25.2; } \\
\text { hockey players }(n=60) \text {, runners } \\
(n=40) \text { and health club gym } \\
\text { members } n=69 \text { ) } \\
\text { group of a control non-exercisers }(n=108)\end{array}$ & $\begin{array}{l}\text { Psychological well-being and physical } \\
\text { self-perception (Ryff's Short } \\
\text { Standardized 18-item scale of Objective } \\
\text { Psychological Well-being, Fox's } \\
\text { Physical Self-Perception Profile (PSPP) } \\
\text { and the Physical } \\
\text { Self-Perception Profile) } \\
\end{array}$ & $\begin{array}{l}\text { Comparing psychological } \\
\text { well-being and physical } \\
\text { self-perception in hockey players, } \\
\text { runners and health club gym } \\
\text { members vs. a control group of } \\
\text { non-exercisers. }\end{array}$ & 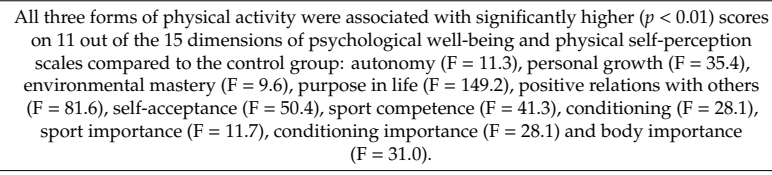 \\
\hline Schnohr et al. [64] & (2005) & Denmark & $\begin{array}{l}\text { Observational } \\
\text { cohort study }\end{array}$ & $\begin{array}{c}n=12,028 \text { participants; } \\
5479 \text { males and } 6549 \text { females; } \\
\text { aged } 20-79\end{array}$ & $\begin{array}{l}\text { Stress (An author-created } \\
\text { questionnaire) }\end{array}$ & $\begin{array}{l}\text { Comparing stress levels between } \\
\text { jogging and various levels of } \\
\text { physical inlactivity in } \\
\text { leisure time }\end{array}$ & 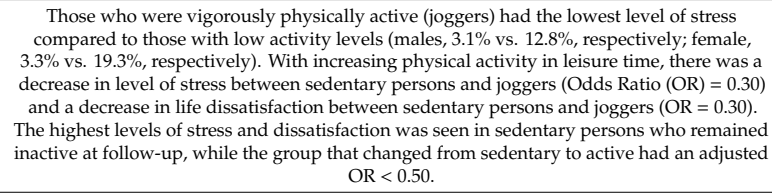 \\
\hline Strachan et al. [65] & (2005) & Canada & $\begin{array}{c}\text { Prospective } \\
\text { longitudinal study }\end{array}$ & $\begin{array}{l}n=67 \text { regular runners; } 32 \text { were } \\
\text { male and } 35 \text { were female; mean } \\
\text { age of } 40.6\end{array}$ & $\begin{array}{l}\text { Self-efficacy and self-identity } \\
\text { (author-created measures of task } \\
\text { self-efficacy and self-regulatory efficacy, } \\
\text { and a 10-item, validated athletic } \\
\text { identity measurement scale) }\end{array}$ & $\begin{array}{l}\text { Investigating the relationship } \\
\text { between running and self-efficacy } \\
\text { and self-identity }\end{array}$ & 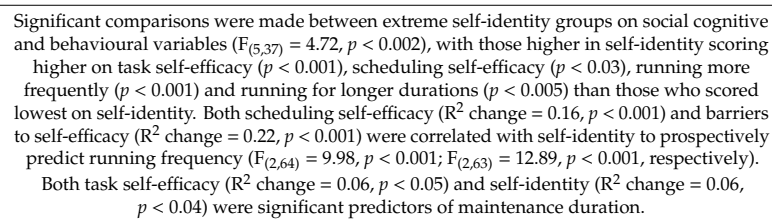 \\
\hline
\end{tabular}


Table 2. Cont

\begin{tabular}{|c|c|c|c|c|c|c|c|}
\hline Author & Year & Country & Design & Population & $\begin{array}{c}\text { Mental Health Outcome } \\
\text { (Measurement) }\end{array}$ & Study Aim & Main Findings \\
\hline Galper et al. [66] & (2006) & USA & $\begin{array}{l}\text { Retrospective } \\
\text { cross-sectional }\end{array}$ & $\begin{array}{l}n=6728 \text { participants; } 5451 \text { males } \\
\text { with a mean age of } 49.5 \text { and } 11277 \\
\text { females with a mean age of } 48.1 \text {; } \\
\text { inactive }(n=1445 \text { men and } \\
n=422 \text { women), insufficiently } \\
\text { active }(n=1892 \text { men and } n=443 \\
\text { women), sufficiently active } \\
(n=1396 \text { men and } n=283 \\
\text { women) and highly active } \\
(n=709 \text { men and } n=129 \text { women })\end{array}$ & $\begin{array}{l}\text { Depression and emotional well-being } \\
\text { (Center for Epidemiological Studies } \\
\text { ccale for Depression and the General } \\
\text { Well-Being Schedule) }\end{array}$ & $\begin{array}{l}\text { Assessing retrospectively if the } \\
\text { level of walking/running } \\
\text { impacted depression and } \\
\text { emotional well-being }\end{array}$ & 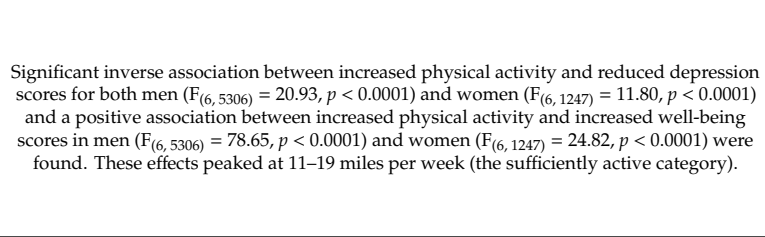 \\
\hline $\begin{array}{c}\text { Luszcynska et al. } \\
{[67]}\end{array}$ & (2007) & UK & $\begin{array}{l}\text { Longitudinal } \\
\text { prospective cohort } \\
\text { study }\end{array}$ & $\begin{array}{l}n=139 \text { runners; } 111 \text { males and } 29 \\
\text { females; mean age of } 29.5 \text {; strong } \\
\quad n=72 \text { and weak }(n=66) \\
\text { maintenance self-efficacy, strong } \\
\quad n=72 \text { and weak }(n=61) \\
\text { recovery self-efficacy, and strong } \\
(n=87 \text { and weak }(n=45) \\
\text { intentions }\end{array}$ & $\begin{array}{l}\text { Self-efficacy and running behaviour } \\
\text { (an author-created questionnaire) }\end{array}$ & $\begin{array}{l}\text { Investigating the relationship } \\
\text { between self-efficacy and running } \\
\text { behaviour with data collected } \\
\text { twice with a time gap of } 2 \text { years }\end{array}$ &  \\
\hline Smith et al. [68]. & (2010) & UK & Cross-sectional & $\begin{array}{l}n=93 \text { non-competitive, regular } \\
\text { runners; } 47 \text { males and } 46 \text { females }\end{array}$ & $\begin{array}{l}\text { Exercise dependence, running } \\
\text { addiction and social physique anxiety } \\
\text { (Exercise Dependence Scale, Running } \\
\text { Addiction Scale and Social Physique } \\
\text { Anxiety Scale) }\end{array}$ & $\begin{array}{l}\text { Comparing exercise dependence, } \\
\text { running addiction and social } \\
\text { physique enxiety in male vs. } \\
\text { female runners }\end{array}$ & 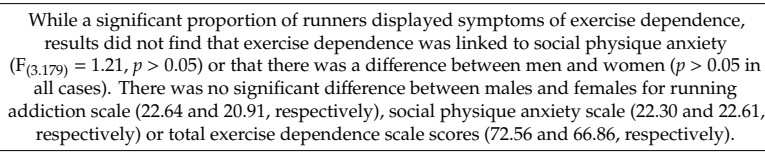 \\
\hline Gapin et al. [69] & (2011) & USA & Cross-sectional & $\begin{array}{l}n=179 \text { regular runners; } 88 \text { males } \\
\text { and } 91 \text { femaless; } 91 \text { obligatory and } \\
88 \text { non-obligatory runners }\end{array}$ & $\begin{array}{l}\text { Disordered eating (Eating Disorder } \\
\text { Inventory, Athletic Identity } \\
\text { Measurement SCale and Obligatory } \\
\text { Exercise Questionnaire) }\end{array}$ & $\begin{array}{l}\text { Comparing disordered eating in } \\
\text { obligatory and non-obligatory } \\
\text { runners. }\end{array}$ & 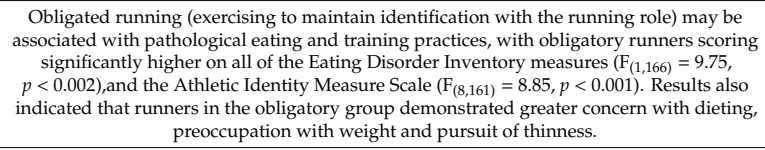 \\
\hline Wadas [70] & (2014) & USA & Cross-sectional & $\begin{array}{c}n=68 \text { male, high school cross } \\
\text { country runners; mean age } 15.9\end{array}$ & $\begin{array}{l}\text { Disordered eating behaviours } \\
\text { (questionnaire consisting of The } \\
\text { Exercise Motivation Inventory 2, } \\
\text { the Eating Attitudes Test } 26 \text { and the } \\
\text { ATHLETE questionnaire) }\end{array}$ & $\begin{array}{l}\text { Investigating any relationship } \\
\text { between male runners with } \\
\text { disordered eating behaviours and } \\
\text { eating attitudes }\end{array}$ & 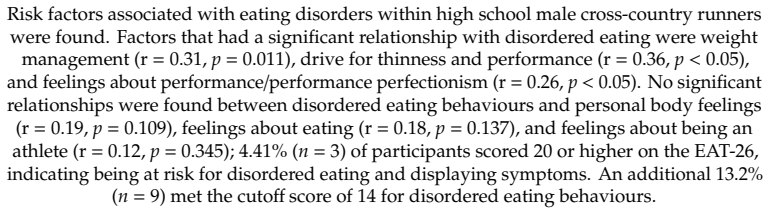 \\
\hline Samson et al. [71] & (2015) & USA & Cross-sectional & $\begin{array}{c}n=308 \text { marathon runners; } \\
177 \text { males and } 191 \text { females; } \\
\text { mean age } 41\end{array}$ & $\begin{array}{l}\text { Self-esteem and psychological coping } \\
\text { (Motivation for Marathons Scale, } \\
\text { The Perceived control questionnaire } \\
\text { and Sport Mental Toughness } \\
\text { Questionnaire) }\end{array}$ & $\begin{array}{l}\text { Investigating the relationship } \\
\text { between self-esteem and } \\
\text { psychological coping with } \\
\text { marathon running }\end{array}$ &  \\
\hline
\end{tabular}


Table 2. Cont

\begin{tabular}{|c|c|c|c|c|c|c|c|}
\hline Author & Year & Country & Design & Population & $\begin{array}{c}\text { Mental Health Outcome } \\
\text { (Measurement) }\end{array}$ & Study Aim & Main Findings \\
\hline Lucidi et al. [72] & (2016) & Italy & $\begin{array}{l}\text { Cross-sectional } \\
\text { prospective field } \\
\text { study }\end{array}$ & $\begin{array}{l}n=669 \text { runners training for a } \\
\text { marathon; } 569 \text { males and } 100 \\
\text { females; mean age } 42.07\end{array}$ & $\begin{array}{l}\text { Stress (Perceived Stress Scale, } \\
\text { the Passion Scale and The Italian } \\
\text { version of the Locomotion and } \\
\text { Assessment Scales) }\end{array}$ & $\begin{array}{l}\text { Investigating the relationship } \\
\text { between running and stress in } \\
\text { runners training for a marathon }\end{array}$ &  \\
\hline$\underset{[73]}{\text { Batmyagmar et al. }}$ & (2019) & Austria & $\begin{array}{c}\text { Prospective } \\
\text { longitudinal study }\end{array}$ & $\begin{array}{l}n=99 \text { participants; } n=50 \text { elderly } \\
\text { marathon runners, mean age of } \\
66 \text {, with } 46 \text { men and } 4 \text { women vs. } \\
n=4 \text { von-exerising controls, } \\
\text { mean age of } 66 \text {, with } 44 \text { men and } \\
5 \text { women } \\
\end{array}$ & $\begin{array}{l}\text { Self-reported health and well-being } \\
\text { and quality of fife (Short Form Health } \\
\text { Survey-36) }\end{array}$ & $\begin{array}{l}\text { Comparing self-reported health } \\
\text { and well-being, } \\
\text { and quality of lile over y years in } \\
\text { elderly marathon runners to } \\
\text { non-exercising controls }\end{array}$ & $\begin{array}{l}\text { Findings suggested that extensive high-intensity endurance exercise is linked with improved } \\
\text { subjective health and well-being in elderly persons, with athletese evaluating their health as } \\
\text { better than non-athletete in the followining categories: general health perception ( } \mathrm{F}=14.21 \\
p<0.001) \text {, vitality }(\mathrm{F}=13.37, p<0.001) \text {, social functioning }(\mathrm{F}=11.30, p<0.001) \text {, emotional } \\
\text { role functioning }(\mathrm{F}=1.42, p<0.002) \text { and mental health }(\mathrm{F}=6.07, p<0.0016) \text {. }\end{array}$ \\
\hline Cleland et al. [74] & (2019) & Australia & Cross-sectional & $\begin{array}{l}372 \text { participants of "Parkrun" } \\
\text { events; mean age } 43.8\end{array}$ & $\begin{array}{l}\text { Enjoyment, self-efficacy and factors of } \\
\text { participation in Parkrun event } \\
\text { (author-created questionnaires). }\end{array}$ & $\begin{array}{l}\text { Investigating enjoyment, } \\
\text { self-efficacy and factors of } \\
\text { participation in Parkrun ovent } \\
\text { participants }\end{array}$ & 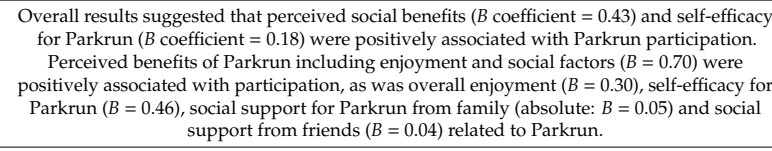 \\
\hline Lukacs et al. [75] & (2019) & Hungary & Cross-sectional & $\begin{array}{l}n=257 \text { amateur runners with at } \\
\text { least } 2 \text { years of running } \\
\text { experience, } 131 \text { males and } 126 \\
\text { females; mean age } 40.49\end{array}$ & $\begin{array}{l}\text { Exercise addiction and psychological } \\
\text { features (Exercise Dependence Scale; } \\
\text { a Cantril ladder for Overall life } \\
\text { satisfaction; SCOFF eating disorder } \\
\text { questionnaire; the UCLA 3-item } \\
\text { Loneliness Scale; Body Image Subscale } \\
\text { from Body Investment scale; and the } \\
\text { Depression, Anxiety and Stress } \\
\text { Scale-21). }\end{array}$ & $\begin{array}{l}\text { Investigating the prevalence of } \\
\text { exercise addiction and } \\
\text { psychological features in amateur } \\
\text { runners, including perceived } \\
\text { health, life satisfaction, loneliness, } \\
\text { stress, anxieity, depression, body } \\
\text { shape and eating disorders }\end{array}$ & $\begin{array}{l}\text { Respondents (137) were characterized as nondependent symptomatic, } 97 \text { were nondependent } \\
\text { asymptomatic and } 23 \text { were at risk of exercise addiction. Results found that five variables } \\
\text { significantly predicted the risk of exercise addiction in runners: weekly time spent running, } \\
\text { childhood physical activity, lowere educational attaininment, anxiety and loneliness (rangese of } \mathrm{B} \\
=0.47 \text { to } 2.06,95 \% \text { CI for odds ratio }=1.61 \text { to } 7.86, p<0.001 \text { to } p=0.023 \text { ). }\end{array}$ \\
\hline
\end{tabular}




\subsubsection{Runners Versus Non-Running Comparisons}

Sixteen of the 47 studies directly compared measures of mental health in runners and non-running comparisons $[29,33,36,37,40-42,45-47,57,61-64,73]$. They found that runners had lower depression and anxiety [33,36,37,40,41,45-47,62], lower stress [64], higher psychological well-being [63,73], and better mood [29] compared to sedentary controls. In these studies, there was no evidence of increased prevalence of eating psychopathology in non-elite runners $[42,57,61]$.

\subsubsection{Runners Only}

Nineteen studies only included runners $[30,31,34,35,39,44,48,49,51,55,58,65-67,70,74-76]$ and compared different levels and types of running. Some studies found a positive association with higher self-identity runners and low levels of depression and high self-efficacy $[30,65-67,74]$. Studies investigating marathon training found a positive relationship of marathon training with self-esteem and psychological coping [55,71]. Two questionnaires of long-distance runners found a correlation between long-distance running and disordered eating behaviours, with obligatory runners (obsessive runners who sacrificed commitments and relationships for running and suffered withdrawal symptoms if they missed a run) exhibiting traits characteristic of anorexia nervosa patients [39] and risk factors for eating disorders identified within male high school cross-country runners [70]. One study of runners training for a marathon suggested that running did not directly impact stress [72]. There were conflicting results from papers investigating negative addiction; one indicated that with more years spent running came a greater risk of negative addiction [34], while another found no relationship between years of running and addiction [58] and another found a sex difference in that commitment to running can occur without addiction in female runners but not in males [49]. Another paper found that five variables significantly predicted risk of exercise addiction in runners: weekly time spent running, childhood PA, lower educational attainment, anxiety and loneliness [75]. The remaining four cross-sectional studies of runners only found that, since participating in running, they had better emotional well-being, relief of tension, self-image and self-confidence, mood, depression, aggression and anger, anxiety and happiness, but not all reported significance or effect size [31,35,44,48,51].

A further eight studies compared groups of runners $[32,38,50,53,56,60,68,69]$. One paper found that females jogging with greater intensity had significantly less anxiety than those jogging at lower intensities [38]. The results from these studies showed that obligatory runners had significantly higher anxiety [53] and eating disorder measures [60,69] than non-obligatory runners and that female obligatory runners are most at risk of eating pathophysiology [60]. Non-elite marathoners showed significantly higher exercise dependence scores [56] but had more self-sufficient personalities compared to recreational runners who did not run marathons [32]. One paper did not find that exercise dependence was linked to social physique anxiety [68], while another found that runners classified as pain runners (pushed themselves until they felt pain) experienced significantly more death thoughts and death anxiety than non-pain runners [50].

\subsubsection{Runners Compared to Individuals with Eating Disorders}

Two studies compared runners to individuals with diagnosed eating disorders but neither indicated that habitual running led to development of disordered eating or body-image problems [52,59].

\subsubsection{Prevented Runners}

One study found that habitual runners prevented from running by illness or injury had significantly greater overall psychological distress, depression and mood disturbance than continuing runners as well as significantly lower self-esteem and body-image [43]. 


\subsubsection{Runners Compared to Gym Exercisers}

A study comparing negative addiction in runners versus gym exercisers found significant association between years of participation in running and gym exercise with negative addiction, regardless of activity type [54].

\subsubsection{Summary of Cross-Sectional Evidence}

Consistent evidence was found for a positive association between positive mental health outcomes and habitual or long-term recreational running compared to non-runners. In contrast, there was evidence that high or extreme levels of running (high frequency and long distance including marathon running) were associated with markers of running ill-health compared to levels of moderate running.

\subsection{Category 2: Acute Bouts of Running}

Narrative description of findings of the 35 studies with an acute bout of running are included within Tables S2-S4 within the supplementary material.

\subsubsection{Single Bouts}

Twenty-three studies incorporated a design using a single bout of running to compare pre-post measurements of mood and short-term measures of mental health (Table 3) [77-99]. Twenty-two of these found positive improvement in measures of mental health (including anxiety, depression and mood); however, one found a decrease in self-efficacy of children following participation in gymnasium PACER (progressive aerobic cardiovascular endurance run) running challenge [95].

Eleven studies used a single bout of treadmill running, and all found positive pre-post differences in mental health outcomes [84-86,88-93,97,99]. Results found significant reductions in state-trait anxiety; total mood disturbance; and POMS subscales of anxiety, depression and confusion. A single bout of treadmill running also significantly improved self-esteem; psychological well-being; children and adolescent self-efficacy; state anxiety, depression and totally mood disturbance; adult self-efficacy; and general affective response. One study found that mood improvements were not evident until 40 min of running [88], while another found that depressed individuals participating in a treadmill run with increasing gradient improved depressed mood immediately post-run but that depressed mood increased at 30-min postexercise [93].

Three studies used a single bout of track running and found significant decreases in anxiety $[78,87]$ and total mood disturbance [81]. Two studies found that a single outdoor run significantly improved depression scores and that even a 10-min jog caused significant mood enhancement [80,94]. Two studies found that a single bout of self-paced running significantly reduced all but one of the POMS subscales and had significant positive changes in all measures of states of affect $[82,96]$.

There were significant improvements for self-esteem, stress and total mood disturbance following a 5-km Parkrun [98], while a 3-mile "fun-run" increased positive mood and decreased negative mood [83]. Two studies used longer runs as exposures: one found that a 1-h run significantly reduced anxiety and nonsignificantly reduced depression [79], while the other found that a 12.5-mile jog significantly improved pleasantness; decreased trait anxiety; nonsignificantly increased activation; and reduced state-anxiety, sadness, anxiety, depression and relaxation subscales [77]. 
Table 3. Summary of data extraction from the 23 single-bout studies.

\begin{tabular}{|c|c|c|c|c|c|c|c|}
\hline Author & Year & Country & Design & Population & $\begin{array}{c}\text { Mental Health Outcome } \\
\text { (Measurement) }\end{array}$ & Study Aim & Main Findings \\
\hline Nowlis et al. [77] & (1979) & Canada & $\begin{array}{l}\text { Pre-post non-controlled } \\
\text { study }\end{array}$ & $\begin{array}{l}n=18 \text {, experienced joggers; } 5 \text { females } \\
\text { and } 13 \text { males; age range } 17 \text { to } 55\end{array}$ & $\begin{array}{l}\text { Mood and anxiety (Mood } \\
\text { Adjective Checklist and State } \\
\text { Trait Anxiety Inventory) }\end{array}$ & $\begin{array}{l}\text { Impact of a 12.5-mile jog on mood } \\
\text { and anxiety }\end{array}$ & $\begin{array}{c}\text { Significant improvement in measures of pleasantness }(2.00 \text { to } 2.67, p<0.01) \text {; } \\
\text { a significant decrease in trait anxiety (34.81 to } 33.31, p<0.10 \text {; } ; \text { nonsignificant } \\
\text { increase in activation; a aeduction in state-antiety a and a reduction of sadness, } \\
\text { anxiety, depression and relaxation subscales }\end{array}$ \\
\hline Wilson et al. [78] & (1981) & Canada & Pre-post controlled study & $\begin{array}{l}n=42 ; 20 \text { runners, } 12 \text { aerobics class } \\
\text { exercisers vs. } 10 \text { people having lunch; } \\
23 \text { females and } 19 \text { males; age range } 21 \\
\text { to } 28\end{array}$ & $\begin{array}{l}\text { Anxiety (State-Trait Anxiety } \\
\text { Inventory) }\end{array}$ & $\begin{array}{l}\text { Impact of a solo indoor track run } \\
\text { on anxiety }\end{array}$ & Significant decrease in anxiety post-activity $\left(\mathrm{F}_{(1,39)}=15.63, p<0.003\right)$ \\
\hline Markoff et al. [79] & $(1982)$ & Hawaii & Pre-post non-controlled & $\begin{array}{l}n=15 \text {, all had run at least } 1 \text { marathon; } \\
11 \text { males and } 4 \text { females; aged } 23-45\end{array}$ & Mood (Profile of Mood States) & Impact of a 1-h run on mood & $\begin{array}{l}\text { Significant reduction in anxiety }(t=2.72, p<0.01) \text { and a nonsignificant } \\
\text { reduction in depression }(t=1.80, n . s .)\end{array}$ \\
\hline Thaxton et al. [80] & (1982) & USA & $\begin{array}{l}\text { Non-randomised } \\
\text { controlled trial }\end{array}$ & $\begin{array}{l}n=33 \text {, regular runners; } 24 \text { males and } 9 \\
\text { females, mean age } 36 ; \text {; groups: outdoor } \\
\text { running test }(n=6) \text {, pre-test but no } \\
\text { running test }(n=9) \text {, no pre-etest but } \\
\text { running test }(n=11) \text {, and no pre-test and } \\
\text { no running test }(n=7) \text {. }\end{array}$ & Mood (Profile of Mood States) & $\begin{array}{l}\text { Impact of } 30 \text { min outdoor } \\
\text { running on mood }\end{array}$ & $\begin{array}{l}\text { Significant differences in the depression scores between the } 30 \text { min outdoor } \\
\left.\text { running group and abstaining groups ( }\left(\mathrm{F}_{1,29}\right)=4.8, p<0.05\right) \text { but no significant } \\
\text { differences between anxiety, vigour and fatigue scores }\end{array}$ \\
\hline $\begin{array}{c}\text { McGowan et al. } \\
{[81]}\end{array}$ & (1991) & USA & $\begin{array}{l}\text { Non-randomised } \\
\text { controlled trial }\end{array}$ & $\begin{array}{l}n=72 \text {, college students; } 25 \text { joggers vs. } 11 \\
\text { karate vs. } 26 \text { weight lifters vs. } 10 \text { science } \\
\text { lecture class members }\end{array}$ & Mood (Profile of Mood States) & $\begin{array}{l}\text { Impact of } 75 \text { min of jogging on an } \\
\text { outdoor track on mood }\end{array}$ & $\begin{array}{l}\text { Significant decrease in total mood disturbance from pre- (35.68) to post- }(24.16 \\
\text { test ( } \mathrm{t}_{24}=2.84, p<0.009 \text { ) following } 75 \text { min of jogging on a track }\end{array}$ \\
\hline Goode et al. [82] & (1993) & USA & Pre-post non-controlled & $\begin{aligned} n= & 150, \text { regular runners; } 104 \text { males, } \\
& 36 \text { females; mean age } 31.7\end{aligned}$ & Mood (Profile of Mood States) & $\begin{array}{l}\text { Impact of own training for } \\
\text { running on mood }\end{array}$ & 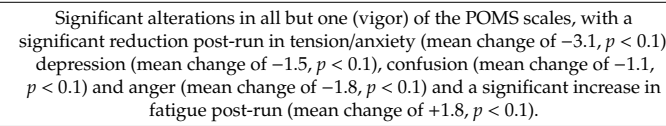 \\
\hline Morris et al. [83] & (1994) & UK & Pre-post non-controlled & $\begin{array}{l}n=165 \text {, members of a road runners club; } \\
98 \text { males and } 67 \text { females; mean age } 34\end{array}$ & $\begin{array}{l}\text { Mood (author-devised adjective } \\
\text { checklist based on POMS) }\end{array}$ & $\begin{array}{l}\text { Impact of a } 3 \text { mile "fun-run" on } \\
\text { mood }\end{array}$ & $\begin{array}{l}\text { Increase in positive mood }\left(\mathrm{F}_{(1.1 .163)}=68.18, p<0.001\right) \text {, decrease in negative mood } \\
\left(\mathrm{F}_{(1.163)}=47.62, p<0.001\right) \text { and greater improvements in mood in women than in } \\
\text { men that was not significant }(p>0.1) \text {. }\end{array}$ \\
\hline Rudolph et al. [84] & (1996) & USA & $\begin{array}{l}\text { Randomised } \\
\text { non-controlled trial }\end{array}$ & $\begin{array}{l}n=36, \text { moderately active female } \\
\text { university students; } n=12 \text { for } 10-, 15- \\
\text { and } 20 \text {-min interventions; mean age } 20.6\end{array}$ & $\begin{array}{l}\text { Self-efficacy (Exercise-Efficacy } \\
\text { Scale) }\end{array}$ & $\begin{array}{l}\text { Impact of various timings of } \\
\text { treadmill running on self-efficacy } \\
(10,15 \text { and } 20 \text { min) }\end{array}$ &  \\
\hline Cox et al. [85] & (2001) & USA & $\begin{array}{l}\text { Randomised controlled } \\
\text { trial }\end{array}$ & $\begin{array}{c}n=24 \text {, physically active male university } \\
\text { students; mean age of } 28.3\end{array}$ & $\begin{array}{l}\text { Psychological affect and } \\
\text { well-being (subjective Exercise } \\
\text { Experiences Scale) }\end{array}$ & $\begin{array}{l}\text { Impact of } 30 \mathrm{~min} \text { of treadmill } \\
\text { jogging at either } 50 \% \text { or } 75 \% \\
\text { predicted } \mathrm{VO}_{2} \text { max on } \\
\text { psychological affect and } \\
\text { well-being }\end{array}$ & $\begin{array}{l}\text { Significant improvement in psychological well-being following an acute bout of } \\
\text { aerobic exercise }\left(p=0.037, \eta^{2} \mathrm{p}=0.07\right)\end{array}$ \\
\hline $\begin{array}{l}\text { O'Halloran et al. } \\
{[86]}\end{array}$ & (2002) & Australia & Pre-post non-controlled & $\begin{array}{l}n=50, \text { regular runners; } 25 \text { males and } 25 \\
\quad \text { females; mean age } 26.6\end{array}$ & $\begin{array}{l}\text { Mood (Profile of Mood States and } \\
\text { Beliefs Concerning Mood } \\
\text { Improvements Associated with } \\
\text { Running Scale) }\end{array}$ & $\begin{array}{l}\text { Impact of a } 60 \text {-min treadmill run } \\
\text { on mood }\end{array}$ & $\begin{array}{l}\text { Significant reductions in anxiety (composed-anxious POMS scale }=25.6 \text { to } 29.12 \\
p<0.05, \text { i.e., more composed-less anxious) and depression (elated-depressed } \\
\text { POMS scale }=24.56 \text { to } 27.10, p<0.01 \text {, i.e., more elated-less depressed) }\end{array}$ \\
\hline Szabo et al. [87] & (2003) & UK & $\begin{array}{l}\text { Pre-post non-controlled } \\
\text { time series } \\
\text { quasi-experimental }\end{array}$ & $\begin{array}{l}n=39 \text {, sports science university students; } \\
22 \text { males and } 17 \text { females; aged } 20-23\end{array}$ & $\begin{array}{l}\text { Anxiety, positive well-being and } \\
\text { psychological distress } \\
\text { (Spielberger State Anxiety } \\
\text { Inventory and Exercise induced } \\
\text { Feeling Inventory) } \\
\end{array}$ & $\begin{array}{l}\text { Impact of } 20 \text { min of track running } \\
\text { on anxiety and feelings }\end{array}$ & $\begin{array}{l}\text { Significant reduction in state anxiety }\left(\mathrm{F}_{(1.5 .55 .3)}=5.32, p<0.01\right) \text { and a positive } \\
\text { effect on psychological distress and positive well-being }\end{array}$ \\
\hline $\begin{array}{l}\text { O'Halloran et al. } \\
{[88]}\end{array}$ & (2004) & Australia & $\begin{array}{l}\text { Randomised controlled } \\
\text { trial }\end{array}$ & $\begin{array}{l}n=160 \text { regular runners; } 80 \text { did run vs. } 80 \\
\text { no running; } 80 \text { males and } 80 \text { females; } \\
\text { aged } 18-40\end{array}$ & $\begin{array}{l}\text { Mood (Profile of Mood States and } \\
\text { Beliefs Concerning Mood } \\
\text { Improvements Associated with } \\
\text { Running Scale). }\end{array}$ & $\begin{array}{l}\text { Impact of a } 60 \text {-min treadmill run } \\
\text { on mood }\end{array}$ &  \\
\hline Robbins et al. [89] & (2004) & USA & Pre-post non-controlled & $\begin{array}{l}n=168 \text {, inactive children and } \\
\text { adolescents; } 86 \text { males and } 82 \text { females; } \\
\text { mean age } 12.6\end{array}$ & $\begin{array}{l}\text { Self-esteem using the Walking } \\
\text { Efficacy Scale }\end{array}$ & $\begin{array}{l}\text { Impact of a 20-min treadmill run } \\
\text { on self-efficacy in children and } \\
\text { adolescents }\end{array}$ & 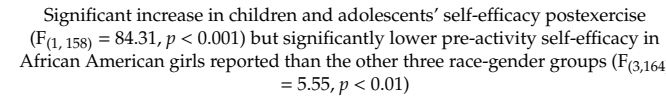 \\
\hline
\end{tabular}


Table 3. Cont

\begin{tabular}{|c|c|c|c|c|c|c|c|}
\hline Author & Year & Country & Design & Population & $\begin{array}{c}\text { Mental Health Outcome } \\
\text { (Measurement) }\end{array}$ & Study Aim & Main Findings \\
\hline Pretty et al. [90] & (2005) & UK & $\begin{array}{l}\text { Randomised controlled } \\
\text { trial }\end{array}$ & $\begin{array}{c}n=100 ; 45 \text { males and } 55 \text { females; mean } \\
\text { age } 24.6\end{array}$ & $\begin{array}{l}\text { Mood and self-esteem (Profile of } \\
\text { Mood States and Rosenberr } \\
\text { Self-Esteem Questionnaire) }\end{array}$ & $\begin{array}{l}\text { Impact of a 20-min treadmill run } \\
\text { with rural vs. urban stimuli on } \\
\text { mood and self-esteem }\end{array}$ & $\begin{array}{l}\text { Significant increase in self-esteem (from } 19.4 \text { to } 18.1 \text { on the Rosenberg } \\
\text { Selff-Esteem Questionnaire, } p<0.001) \text {, with rural and urban pleasant stimuli } \\
\text { producing a significantly greater positive effect on self-esteem than exercise } \\
\text { alone, while both rural and urban unpleasant sceneses reduced the positive effects } \\
\text { of exercise on self-esteem }\end{array}$ \\
\hline Hoffman et al. [91] & (2008) & USA & $\begin{array}{l}\text { Pre-post pre-experimental } \\
\text { study }\end{array}$ & $\begin{array}{l}n=32 ; 16 \text { regular exercisers and } 16 \\
\text { non-exercisers; } 8 \text { males and } 8 \text { females in } \\
\text { each group }\end{array}$ & Mood (Profile of Mood States) & $\begin{array}{l}\text { Impact of a 30-min treadmill run } \\
\text { on mood }\end{array}$ & $\begin{array}{l}\text { Decreased total mood disturbance in a } 30 \text {-min treadmill run in both regular } \\
\text { exercisers }(-16 \text { points, , } 55 \% \mathrm{CI}=-24 \text { and non-exercisers (- }- \text { points, 95\% } \\
\mathrm{CI}=1-18) \text { but almost double the effect in exercisers. }\end{array}$ \\
\hline Kwan et al. [92] & (2010) & USA & Pre-post non-controlled & $\begin{array}{c}n=129 ; 62 \text { males and } 67 \text { females; mean } \\
\text { age } 22\end{array}$ & $\begin{array}{l}\text { General affective response } \\
\text { (Physical Activity Affect scale) }\end{array}$ & $\begin{array}{l}\text { Impact of a } 30 \text {-min treadmill run } \\
\text { on general affective response }\end{array}$ & $\begin{array}{l}\text { Positive effect of the run on general affective response during exercise }(\mathrm{b}=0.52 \\
\mathrm{SE}=0.09, p<0.0001) \text { and } 15 \text { min postexercise }(\mathrm{b}=0.73, \mathrm{Cl} 95=0.56,0.89 \\
\left.\mathrm{t}_{(126)}=8.63, p<0.0001\right) .\end{array}$ \\
\hline $\begin{array}{l}\text { Weinstein et al. } \\
\quad[93]\end{array}$ & (2010) & USA & Pre-post controlled study & $\begin{array}{c}n=30 ; 15 \text { males and } 15 \text { females; } 2 \text { with } \\
\text { minor depressive disorder, } 12 \text { with major } \\
\text { depressive dissorder and } 16 \text { as controls; } \\
\text { mean age } 39.8\end{array}$ & $\begin{array}{l}\text { Mood and depression (Becks } \\
\text { depression Inventory scale and } \\
\text { Profile of Mood States) }\end{array}$ & $\begin{array}{l}\text { Impact of } 25 \text { min of increasing } \\
\text { graded treadmill running on } \\
\text { mood and depression }\end{array}$ & $\begin{array}{l}\text { Not only improvements in depressed mood immediately following exercise } \\
(p=0.02) \text { of } 25 \text { min of increasing graded treadmill running but also increased } \\
\left.\text { depressed mood at } 30 \text { min postexercise } F_{(1,27)}=3.98 ; p=0.05 ; p^{2}=0.13\right) \text { and } \\
\text { significant relation between the severity of depression and increases in } \\
\text { depressed mood }(\mathrm{r}=0.60, p=0.001) \text { at } 30 \text { min postexercise }\end{array}$ \\
\hline $\begin{array}{c}\text { Anderson et al. } \\
{[94]}\end{array}$ & (2011) & UK & $\begin{array}{l}\text { Randomised controlled } \\
\text { trial } 2 \times 2 \text { mixed design }\end{array}$ & $\begin{array}{l}n=40, \text { from various sports clubs; aged } \\
18-25\end{array}$ & $\begin{array}{l}\text { Mood ("Incredibly Short Profile } \\
\text { of Mood States") }\end{array}$ & $\begin{array}{l}\text { Impact of a light 10-min outdoor } \\
\text { jog on mood }\end{array}$ & $\begin{array}{l}\text { Significant mood enhancement even with a light } 10=\text { min jog on a grass playing } \\
\text { field }\left(\mathrm{F}_{(1,38)}=24.18, p<0.001, \mathrm{n}_{\mathrm{p}}^{2}=0.39\right) \text { compared with a } 10 \text {-min cognitive task }\end{array}$ \\
\hline Kane et al. [95] & (2013) & USA & Pre-post non-controlled & $\begin{array}{l}n=34 \text { school children; } 16 \text { males and } 18 \\
\quad \text { females; aged 11-14 }\end{array}$ & $\begin{array}{l}\text { Self-efficacy (Self-efficacy } \\
\text { questionnaire adapted for } \\
\text { children) }\end{array}$ & $\begin{array}{l}\text { Impact of the running PACER } \\
\text { challenge (20 m sprints with } \\
\text { increasing pace inside a } \\
\text { gymnasium on self-efficacy } \\
\text { in children }\end{array}$ & $\begin{array}{l}\text { Decrease in self-efficacy following participation in the run (from } 2.7 \text { to } 2.3 \\
\text { following exercise, } t=4.6, p<0.001 \text {, large effect size of } d=0.79 \text { ) but positive } \\
\text { correlation between PACER laps and pre-and post-measures of exercise } \\
\text { self-efficacy }\end{array}$ \\
\hline Szabo et al. [96] & (2013) & Hungary & Pre-post non-controlled & $\begin{array}{c}n=50 \text { recreational runners; } 37 \text { males and } \\
13 \text { females mean age } 29.02\end{array}$ & $\begin{array}{l}\text { States of affect using the Exercise } \\
\text { Induced Feeling Inventory }\end{array}$ & $\begin{array}{l}\text { Impact of a } 5 \mathrm{~km} \text { self-paced run } \\
\text { along a public running path on } \\
\text { states of affect }\end{array}$ & 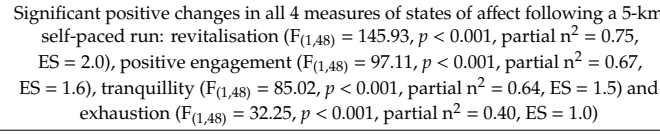 \\
\hline $\begin{array}{l}\text { McDowell et al. } \\
{[97]}\end{array}$ & (2016) & Ireland & $\begin{array}{l}\text { Randomised controlled } \\
\text { trial }\end{array}$ & $\begin{array}{c}n=53 ; 27 \text { males and } 26 \text { females; } \\
\text { mean age of } 21.2\end{array}$ & $\begin{array}{l}\text { Mood and anxiety (Profile and } \\
\text { Mood States and State--Trait } \\
\text { Anxiety Inventory) }\end{array}$ & $\begin{array}{l}\text { Impact of a 30-min treadmill run } \\
\text { on mood and anxiety }\end{array}$ & $\begin{array}{l}\text { Significantly improved state anxiety }\left(\mathrm{F}_{1,92}=12.52, p<0.001\right) \text {, feelings of } \\
\left.\text { depression ( } \mathrm{F}_{1,86}=5.05, p<0.027\right) \text { and total mood disturbance }(\mathrm{F}=36.91, \\
\quad<0.001) \text { compared to } 30 \text { min of seated quiet rest }\end{array}$ \\
\hline $\begin{array}{l}\text { Rogerson et al. } \\
{[98]}\end{array}$ & (2016) & UK & $\begin{array}{l}\text { Pre-post non-controlled } \\
\text { mixed between-within }\end{array}$ & $\begin{array}{l}n=331 \text { Parkrun attendees; } 180 \text { males and } \\
151 \text { females; mean age } 40.8\end{array}$ & $\begin{array}{l}\text { Psychological well-being } \\
\text { (Questionnaire containing parts } \\
\text { of the Profile of Mood States, } \\
\text { Rosenberge Self-esteem Scale and } \\
\text { Perceived Stress Scale) } \\
\end{array}$ & $\begin{array}{l}\text { Impact of a 5-km park run on } \\
\text { psychological well-being }\end{array}$ & $\begin{array}{c}\text { Significant }(p<0.001) \text { improvements post-run for self-esteem }(7.7 \% \\
\left.\text { improvement } \mathrm{F}_{(1,324)}=100.58, \eta^{2}=0.24\right) \text {, stress }(18.4 \% \text { inprovement; } \\
\left.\mathrm{F}_{(1,315)}=50.78, \eta^{2} p=0.199\right) \text { and total mood disturbance }(14.2 \% \text { improvement } \\
\left.\mathrm{F}_{(1,278)}=22.15, \eta^{2} \mathrm{p}=0.07\right)\end{array}$ \\
\hline Edwards et al. [99] & (2017) & USA & $\begin{array}{c}\text { Randomised controlled } \\
\text { trial }\end{array}$ & $\begin{array}{c}n=27 ; 8 \text { joggers vs. } 9 \text { walkers vs. } 10 \\
\text { stretchers; aged } 18-35\end{array}$ & $\begin{array}{l}\text { Stress and anxiety } \\
\text { (Exercise-Induced Feeling } \\
\text { Inventory and Affective } \\
\text { Circumplex Scale, and the } \\
\text { Strait-Trait Anxiety Inventory) }\end{array}$ & $\begin{array}{l}\text { Impact of a 15-min treadmill jog } \\
\text { on stress and anxiety }\end{array}$ & 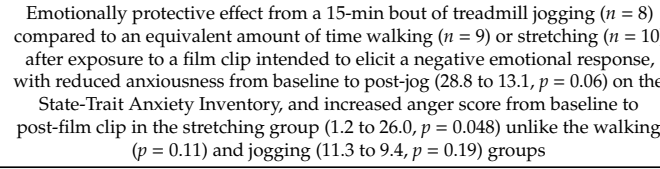 \\
\hline
\end{tabular}




\subsubsection{Double Bouts}

There were nine studies that had a double-bout design [100-108] (Table 4). Eight of the nine studies were primarily designed to compare conditions rather than to compare the impact of running on mental health, including green/park versus urban, solo versus group, different pacing and different durations of running [101-108]. Seven of the eight studies found that markers of mental health improved significantly after running [101-107]. Only one study was designed to primarily assess the impact of running on mental health, and although there was no control, they found higher mood and feelings of pleasantness post-run but these "did not reach significance" [100].

Four studies compared park/rural versus urban running, and all found measures of mental health including anxiety, depression, mood and self-esteem improved post-run [103-105,107]. No paper reported a statistically significant difference in emotional benefit between park and urban conditions. Two studies compared solo versus group running: one found that anxiety reduced following both group and solo running [101], while the other found that children's anxiety levels increased nonsignificantly following individual and group running [108]. One study compared 10- and 15-min runs and found that they produced similar psychological benefits to mood [102]. Another compared a self-paced versus prescribed-paced run and found higher self-efficacy before the prescribed-paced run compared to the self-paced run [106].

\subsubsection{Triple Bouts}

Three studies used three bouts of running (Table 5) [109-111]. One study found that, while two indoor runs had a positive effect on mood, the outdoor run had an even greater benefit to mood with subjects feeling less anxious, depressed, hostile and fatigued and feeling more invigorated [109]. Another study also used 3 runs of varying intensities and found significant overall mood benefits postexercise but no significant differences between intensities [110]. One study compared 3 intensities of treadmill exercise to a sedentary control condition and found that state anxiety improved following running at $5 \%$ below and at the lactate threshold but that anxiety increased after running at $5 \%$ above the lactate threshold [111]. Overall, these studies suggest that running improves mood, that outdoor running has a greater benefit to mood and that most intensities of running improve mood, with the exception of an intensity markedly above the lactate threshold. However, only one study included a control condition [111].

\subsubsection{Summary of Acute Bouts}

Overall, these studies suggest that acute bouts of running can improve mental health and that the type of running can lead to differential effects. The evidence suggests that acute bouts of treadmill, track, outdoor and social running (2.5-20 km and 10-60 $\mathrm{min}$ ) all result in improved mental health outcomes. There were few differences between high and low intensities. Studies consistently show that any running improves acute/short-term mood markers, but the lack of inactive comparison conditions is a limitation to the strength of the evidence. Little variation in the demographics of participants and small sample sizes limit generalizability and precision of findings. 
Table 4. Summary of data extraction from the 9 double-bout studies.

\begin{tabular}{|c|c|c|c|c|c|c|c|}
\hline Author & Year & Country & Design & Population & $\begin{array}{l}\text { Mental health Outcome } \\
\text { (Measurement) }\end{array}$ & Study Aim & Main Findings \\
\hline Krotee [108] & (1980) & USA & $\begin{array}{l}\text { Pre-post pre-experimental } \\
\text { non-controlled }\end{array}$ & $n=78$, children aged $7-12$ & $\begin{array}{l}\text { Anxiety (State-Trait Inventory for } \\
\text { Children) }\end{array}$ & $\begin{array}{l}\text { Impact of 50-metre group vs. } \\
\text { solo run on anxiety }\end{array}$ & $\begin{array}{l}\text { Children's anxiety levels increased nonsignificantly following a run in } \\
\text { either an individual (30.54 to } 32.72, n \text {.s.) or a group setting ( } 30.67 \text { to } 31.83 \text {, } \\
n \text { n.s.). }\end{array}$ \\
\hline $\begin{array}{l}\text { Wildmann et al. } \\
{[100]}\end{array}$ & (1986) & Germany & Pre-post non-controlled & $\begin{array}{l}n=21 \text {, male long-distance } \\
\text { runners; mean age of } 29.8\end{array}$ & $\begin{array}{l}\text { Feelings of pleasantness and } \\
\text { changes of mood } \\
\text { (Eigenschaftsworterliste scale } \\
\text { adjective checklist) }\end{array}$ & $\begin{array}{l}\text { Impact of } 2 \text { identical } 10-\mathrm{km} \\
\text { runs }(1 \text { week apart) on } \\
\text { feelings of pleasantness and } \\
\text { change of mood }\end{array}$ & $\begin{array}{l}\text { Higher scores of good mood and feelings of pleasantness were found } \\
\text { following the runs (mean increase of the two runs for all subjects was } 2.79 \\
\text { from a total of } 19 \text { items, but the increase did not reach significance). }\end{array}$ \\
\hline $\begin{array}{l}\mathrm{O}^{\prime} \text { Connor et al. } \\
{[101]}\end{array}$ & (1991) & USA & Pre-post non-controlled & $\begin{array}{l}n=17 \text {, members of local } \\
\text { running clubs; } 10 \text { males } \\
\text { and } 7 \text { females; } \\
\text { mean age } 25\end{array}$ & $\begin{array}{l}\text { Anxiety and body awareness } \\
\text { (State--rrait Anxiety Inventory } \\
\text { and Body Awareness Scale) }\end{array}$ & $\begin{array}{l}\text { Impact of a 5-mile outdoor } \\
\text { group vs. solo run on anxiety }\end{array}$ & $\begin{array}{l}\text { Anxiety levels were reduced following both a group (mean baseline }=34.0 \\
\text { vs. pre-exercise }=42.5 \text { vs. postexercise }=27.5, p<0.05 \text { and solo run }(\text { mean } \\
\text { baseline }=34.0 \text { vs. pre-exercise }=40.0 \text { vs. postexercise }=30.0, p<0.05) .\end{array}$ \\
\hline $\begin{array}{l}\text { Nabetani et al. } \\
\quad[102]\end{array}$ & (2001) & Japan & Pre-post non-controlled & $\begin{array}{l}n=15 \text {, healthy, } \\
\text { moderately active male } \\
\text { graduate students }\end{array}$ & $\begin{array}{l}\text { Mood (Mood Checklist } \\
\text { Short-form 1) }\end{array}$ & $\begin{array}{l}\text { Impact of a 10-min vs. a } \\
\text { 15-min treadmill run on mood }\end{array}$ & 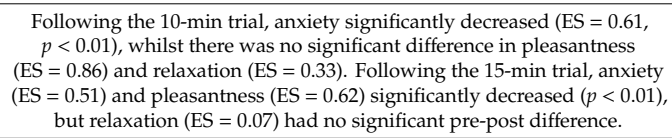 \\
\hline Bodin et al. [103] & (2003) & Sweden & $\begin{array}{l}\text { Pre-post non-controlled } \\
\text { within-subjects }\end{array}$ & $\begin{array}{l}n=12 \text {, regular runners. } 6 \\
\text { male and } 6 \text { female. Mean } \\
\text { age of } 39.7 .\end{array}$ & $\begin{array}{l}\text { Emotional restoration ie. } \\
\text { depression/anxiety } \\
\text { (Exercise-Induced Feeling } \\
\text { Inventory and the Negative } \\
\text { Mood Scale). } \\
\end{array}$ & $\begin{array}{l}\text { Impact of } 1 \mathrm{~h} \text { park vs. urban } \\
\text { run on depression and } \\
\text { anxiety. }\end{array}$ & $\begin{array}{l}\text { Runners preferred the park to the urban environment and perceived it as } \\
\text { more psychologically restorative; there was no statistical difference in } \\
\text { results for park vs. urban settings, with running in both settings causing a } \\
\text { significant decline in anxiety/depression }\left(\mathrm{F}_{1,1,10)}=16.2, p<0.002, \mathrm{r}=0.78 \text {, }\right. \\
\text { effect size }=0.30) .\end{array}$ \\
\hline Butryn et al. [104] & (2003) & USA & $\begin{array}{l}\text { Pre-post non-controlled } \\
\text { within-subjects }\end{array}$ & $\begin{array}{l}n=30, \text { non-elite female } \\
\text { distance runners; mean } \\
\text { age } 31\end{array}$ & $\begin{array}{c}\text { Mood, feeling states and } \\
\text { cognition states (Profile of Mood } \\
\text { States, Exercise-Induced Feeling } \\
\text { Inventory and Thoughts During } \\
\text { Running Scale) }\end{array}$ & $\begin{array}{l}\text { Impact of a 4-mile park vs. } \\
\text { urban run on mood }\end{array}$ & $\begin{array}{l}\text { Total mood disturbance scores decreased by } 8.97(p<0.001) \text {, with a similar } \\
\text { effect following the urban run: total mood disturbance scores decreased by } \\
\qquad 9.13(p<0.001) \text {. }\end{array}$ \\
\hline Kerr et al. [105] & (2006) & Japan & Pre-post non-controlled & $\begin{array}{l}n=22, \text { recreational } \\
\text { runners; mean age 22.7 }\end{array}$ & $\begin{array}{l}\text { Stress and emotions (Tension and } \\
\text { Effort Stress Inventory) }\end{array}$ & $\begin{array}{l}\text { Impact of indoor vs. outdoor } \\
5-\mathrm{km} \text { run on stress and } \\
\text { emotions }\end{array}$ & $\begin{array}{l}\text { Significant pre-post effects irrespective of running condition were found, } \\
\text { with an increase in relaxation }\left(\mathrm{F}_{(1,21)}=5.60, p<0.05\right) \text { and excitement } \\
\left(\mathrm{F}_{(1,21)}=24.65, p<0.001\right) \text { and a decrease in anxiety }\left(\mathrm{F}_{(1,21)}=9.90, p<0.01\right) \text {. }\end{array}$ \\
\hline Rose et al. [106] & (2012) & New Zealand & Pre-post controlled & $\begin{array}{l}n=32 \text {, all females; } 17 \\
\text { sedentary and } 15 \text { active; } \\
\text { mean age } 45\end{array}$ & $\begin{array}{l}\text { Self-efficacy (Self-Efficacy for } \\
\text { Exercise Scale) }\end{array}$ & $\begin{array}{l}\text { Impact of self-paced vs. } \\
\text { prescribed pace } 30-\text { min } \\
\text { treadmill run on self-efficacy }\end{array}$ & $\begin{array}{l}\text { Higher self-efficacy was observed before the prescribed paced run } \\
\text { compared to the self-paced run }\left(\mathrm{F}_{1,28}=5.81 ; p<0.023 ; \mathrm{n}^{2}=0.17\right) \text {. }\end{array}$ \\
\hline Reed et al. [107] & (2013) & UK & Pre-post non-controlled & $\begin{array}{l}n=75, \text { children aged } 11 \\
\text { and } 12\end{array}$ & $\begin{array}{l}\text { Self-esteem (Rosenberg Self } \\
\text { Esteem Scale) }\end{array}$ & $\begin{array}{l}\text { Impact of rural vs. urban } \\
\text { 1.5-mile run on self-esteem }\end{array}$ & $\begin{array}{l}\text { Significant increase in self-esteem }\left(F_{(1,74)}=12.2, p<0.001\right) \text { was found, } \\
\text { but no significant difference between the urban or green exercise condition } \\
\left(F_{(1,74)}=0.13, p=0.72\right) \text { or any significant difference between boys and girls } \\
\text { were found. }\end{array}$ \\
\hline
\end{tabular}


Table 5. Summary of data extraction from the 3 triple-bout studies.

\begin{tabular}{|c|c|c|c|c|c|c|c|}
\hline Author & Year & Country & Design & Population & $\begin{array}{l}\text { Mental Health Outcome } \\
\text { (Measurement) }\end{array}$ & Study Aim & Main Findings \\
\hline Harte et al. [109] & (1995) & Australia & $\begin{array}{l}\text { Pre-post non-randomised } \\
\text { controlled-repeated } \\
\text { measure design }\end{array}$ & $\begin{array}{l}n=10 \text {, male amateur triathletes or } \\
\text { marathon runners with a mean age } \\
\text { of } 27.1\end{array}$ & $\begin{array}{l}\text { Mood (Profile of Mood } \\
\text { States) }\end{array}$ & $\begin{array}{l}\text { Impact of a } 12-\mathrm{km} \text { outdoor run vs. } \\
\text { indoor treadmill run with } \\
\text { external stimuli vs. an indoor } \\
\text { treadmill run with internal } \\
\text { stimuli on mood }\end{array}$ & $\begin{array}{l}\text { While the two indoor runs had a positive effect on } \\
\text { mood, outdoor running had an even greater benefit to } \\
\text { mood with subjects less anxious }\left(\mathrm{F}_{(3,35)}=14.12\right. \\
p<0.005) \text {, less depressed }\left(\mathrm{F}_{(3,35)}=4.16, p<0.01\right) \\
\text { less hostile }\left(\mathrm{F}_{(3,35)}=13.13, p<0.005\right), \text { less fatigued } \\
\left(\mathrm{F}_{(3,35)}=15.09, p<0.005\right) \text { and more invigorated } \\
\left.\mathrm{F}_{(3,35)}=13.01, p<0.005\right) .\end{array}$ \\
\hline $\begin{array}{l}\text { Berger, Owen + } \\
\text { Motl [110] }\end{array}$ & (1998) & USA & $\begin{array}{l}\text { Pre-post non- controlled } \\
\text { study }\end{array}$ & $\begin{array}{c}\text { Study 1: } n=71 \text { college students } \\
\text { (32 males and } 39 \text { females) with a mean } \\
\text { age of 21.39; study } 2: n=68 \text { college } \\
\text { students (28 males and } 40 \text { females) } \\
\text { with a mean age of } 22.22\end{array}$ & $\begin{array}{l}\text { Mood (Profile of Mood } \\
\text { States) }\end{array}$ & $\begin{array}{l}\text { Impact of three } 15-\min \text { runs of } \\
\text { varying intensities (50, } 65 \text { or } 80 \% \\
\text { age-adjusted } \mathrm{HR} \text { max) on mood }\end{array}$ & $\begin{array}{c}\text { Significant overall mood benefits postexercise } \\
\left(\mathrm{F}_{(6.57)}=6.43, p<0.0001\right) \text { for all intensities but no } \\
\text { significant differences between intensities were found. }\end{array}$ \\
\hline $\begin{array}{l}\text { Markowitz et al. } \\
{[111]}\end{array}$ & (2010) & USA & Pre-post controlled trial & $\begin{array}{l}n=28 \text {, college-aged students; } 14 \text { active } \\
\text { vs. } 14 \text { sedentary controls; mean age } 21\end{array}$ & $\begin{array}{l}\text { Anxiety (State-Trait } \\
\text { Anxiety Inventory) }\end{array}$ & $\begin{array}{l}\text { Impact of three 20-min treadmill } \\
\text { runs of varying intensities ( } 5 \% \\
\text { below, } 5 \% \text { above and directly at } \\
\text { lactate threshold) on anxiety }\end{array}$ & $\begin{array}{l}\text { This was the only triple-bout study with a sedentary } \\
\text { control condition. State anxiety improved postexercise } \\
\text { at } 5 \% \text { below (effect size }=-0.38, p<0.001 \text { ) and after } \\
\text { exercise at the lactate threshold (effect size }=-0.20 \text {, } \\
p<0.001) \text {, but anxiety increased at } 5 \% \text { above the lactate } \\
\text { threshold (effect size }=+0.13, p=0.0030 \text { ). }\end{array}$ \\
\hline
\end{tabular}




\subsection{Category 3: Longer-Term Interventions}

Thirty-four studies investigated the effects of more than three bouts of running on measures of mental health ranging from 2-week interventions to 1-year marathon training programmes (Table 6) [112-144]. Narrative description of 34 studies are available in Table S5 within the supplementary material.

Eight studies used 2-8 week running interventions [121,122,125,127,128,132,137,139]. Male regular runners deprived of running for 2 weeks had increased anxiety and depression symptoms compared to continuing runners [125]. Two 3-week interventions both found that mood improved while amateur runners had lesser anxiety on running days compared to non-running days; perceived stress in adolescents did not significantly change [132,137]. A 4-week intervention of regular treadmill running at set paces in moderately trained male runners found that an increase in intensity of runs was associated with significant increase in total mood disturbance while running at a pace with more economical values was associated with more positive mental health profiles [127]. A 7-week non-controlled intervention of weekly 40-min fixed distance outdoor rural runs increased mood in both male and female regular exercising university students, with faster runners scoring higher than slower runners [128]. An 8-week intervention of a combination of weekly group and solo jogging in middle-aged chronically stressed, sedentary women found lower anxiety and greater self-efficacy than baseline and compared to relaxation group controls [121]. Two studies used a 8-week intervention of walking/running with non-treatment controls and found significant improvements in mood and decrease of depression, including in outpatients diagnosed with mild to severe depression [122,139].

Eleven studies used 10-20 week running interventions [114-116,119,123,126,129-131,140,143]. Three 10-week walking/jogging interventions found reductions in anxiety measures, improvement of well-being and conflicting results for changes in depression measures compared to controls [115,119,129]. Another 10-week running intervention found that depression, trait anxiety and state anxiety all decreased significantly while mood improved significantly [114]. A further 10-week running intervention found that, although the exercise group was more likely to use exercise to cope with stress, there were no significant differences in stress or coping measurements between the running and comparison group [123]. Three 12-week interventions found significantly reduced stress and improvements in mood in college students compared to controls, with more mood improvement in males and in females with higher masculinity $[126,130,143]$. One 12-week intervention of self-directed running in recreational runners found that well-being was significantly higher during weeks when individuals ran further and ran more often while self-efficacy was related to distance ran but not to frequency of running [143]. Running interventions of 14-20 weeks improved mood and self-esteem and lowered emotional stress reactivity in college/university students compared with controls [116,131,140]. 
Table 6. Summary of data extraction from the 34 longer-term intervention studies.

\begin{tabular}{|c|c|c|c|c|c|c|c|}
\hline Author & Year & Country & Design & Population & $\begin{array}{l}\text { Mental Health Outcome } \\
\text { (Measurement) }\end{array}$ & Study Aim & Main Findings \\
\hline Lion [112] & (1978) & USA & $\begin{array}{l}\text { Randomised } \\
\text { controlled trial }\end{array}$ & $\begin{array}{l}n=6 \text {, chronic psychiatric patients; } \\
2 \text { males and } 4 \text { females; } 3 \text { had the } \\
\text { running intervention and } 3 \text { were } \\
\text { controls; middle aged }\end{array}$ & $\begin{array}{l}\text { Anxiety and body image } \\
\text { (State-Trait Anxiety Inventory } \\
\text { and Rorschach Inkblot Test for } \\
\text { body-boundary image) }\end{array}$ & $\begin{array}{l}\text { Impact of running a mile } 3 \text { times per } \\
\text { week for } 2 \text { months on anxiety and } \\
\text { body image in chronic psychiatric } \\
\text { patients }\end{array}$ & $\begin{array}{l}\text { Post-test anxiety was significantly reduced in the jogging group vs. control } \\
\text { group ( } \mathrm{t}=3.2, \mathrm{~d} \text {, }=4, p<0.05) \text {. Joggers showed an average drop of } 9 \\
\text { points on the STAI (39.3 to } 30.3 \text { ) from pre- to post-test, while controls } \\
\text { showed an average rise of } 4 \text { points (32.6 to } 636.6) \text {. No statistical difference } \\
\text { was found between groups for post-test body image scores. }\end{array}$ \\
\hline Blue [113] & (1979) & USA & $\begin{array}{c}\text { Pre-post } \\
\text { non-controlled }\end{array}$ & $\begin{array}{c}n=2 \text { former inpatients of a } \\
\text { psychiatric hospitali } 1 \text { male aged } \\
37 \text { and } 1 \text { female aged } 32\end{array}$ & $\begin{array}{l}\text { Depression (Zung depression } \\
\text { scale) }\end{array}$ & $\begin{array}{l}\text { Impact of } 3 \text { runs per week for } 9 \\
\text { weeks on depression }\end{array}$ & $\begin{array}{l}\text { Following running intervention, both patients' depression scores reduced } \\
\text { from "moderately depressed" to "mildly depressed" (decrease of } 18 \text { and } \\
15 \text { points on the Zung Depression Scale). }\end{array}$ \\
\hline Young [114] & (1979) & USA & $\begin{array}{c}\text { Pre-post } \\
\text { non-controlled }\end{array}$ & $\begin{array}{c}n=32 \text { adults; } 4 \text { groups: young } \\
\text { males }(n=8, \text { mean age 30.13), } \\
\text { middle-aged males }(n=8, \text { mean } \\
\text { age } 53.0) \text {, young females }(n=8, \\
\text { mean age 28.25) and middle aged } \\
\text { females }(n=8, \text { mean age 50.25) }\end{array}$ & $\begin{array}{l}\text { Anxiety and depression using the } \\
\text { Multiple Affect Adjective } \\
\text { Checklist }\end{array}$ & $\begin{array}{l}\text { Impact of a 10-week walking/jogging } \\
\text { programme consisting of } 1 \mathrm{~h} 3 \times \text { per } \\
\text { week on anxiety and depression }\end{array}$ & $\begin{array}{l}\text { Significant reductions in pre- to post-test anxiety }\left(\mathrm{F}_{(1,28)}=6.01, p<0.05\right) \\
\text { were found. Results for anxiety and depression both showed significant } \\
\text { age differences in favour of older subjects }\left(\left(\mathrm{F}_{(1,28)}\right)=5.37, p<0.05\right) \text { and } \\
\left(\mathrm{F}_{(1,28)}=5.21, p<0.05\right) \text {, respectively). However, there was no significant } \\
\text { improvement with subject depression scores. }\end{array}$ \\
\hline $\begin{array}{l}\text { Blumenthal et al. } \\
\quad[115]\end{array}$ & (1982) & USA & $\begin{array}{l}\text { Non-randomised } \\
\text { controlled cohort }\end{array}$ & $\begin{array}{c}n=16 \text { healthy adults; } 5 \text { males and } \\
11 \text { females; mean age } 45.1\end{array}$ & $\begin{array}{l}\text { Anxiety and mood (Profile of } \\
\text { Mood States and the State-Trait } \\
\text { Anxiety Inventory) }\end{array}$ & $\begin{array}{l}\text { Impact of } 3 \text { times weekly } \\
\text { walking-jogging programme for } 10 \\
\text { weeks vs. } 10 \text { weeks of sedentary } \\
\text { controls on anxiety and mood }\end{array}$ & 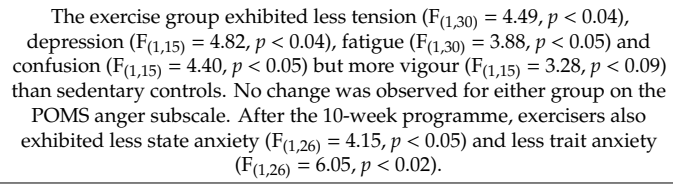 \\
\hline Trujillo [116] & (1983) & USA & $\begin{array}{l}\text { Randomised } \\
\text { controlled trial }\end{array}$ & $\begin{array}{l}n=35 \text { female college students; } \\
13 \text { weight trainers, } 12 \text { runners } \\
\text { and } 10 \text { controls }\end{array}$ & $\begin{array}{l}\text { Self-esteem (Tennessee } \\
\text { Self-concept Scale and the Bem } \\
\text { Sex Role Inventory) }\end{array}$ & $\begin{array}{l}\text { Impact of a 16-week running } \\
\text { programme vs. weight training vs. a } \\
\text { control on self-esteem }\end{array}$ & $\begin{array}{l}\text { Both the running and weight training groups showed a significant increase } \\
\text { in self-esteem from pre- to post-programme }\left(t_{(11)}=2.11, p<0.05\right) \text {, while } \\
\text { the control group showed a nonsignificant loss in self-esteem }\left(\mathrm{t}_{(\mathrm{g})}=0.55,\right. \\
\qquad>0.05) .\end{array}$ \\
\hline $\begin{array}{l}\text { Tuckman et al. } \\
\text { [117] }\end{array}$ & (1986) & USA & $\begin{array}{c}\text { Randomised } \\
\text { non-controlled } \\
\text { trial }\end{array}$ & $n=154$ children; aged 9-11 & $\begin{array}{l}\text { Psychological affects such as } \\
\text { creativity, perceptual function, } \\
\text { behaviour and self-concept } \\
\text { (Alternate Uses Test, } \\
\text { Bender-Gestalt Test, Devereaux } \\
\text { Elementary School Behaviour } \\
\text { Rating Scale and Piers-Harris } \\
\text { Children's Self-Concept Scale) }\end{array}$ & $\begin{array}{l}\text { Impact of three 30-min runs per week } \\
\text { on an outdoor running track for 12 } \\
\text { weeks on psychological affects in } \\
\text { children (creativity, perceptual } \\
\text { function, behaviour and self-concept, } \\
\text { compared to } 12 \text { weeks of the school's } \\
\text { regular physical education }\end{array}$ & $\begin{array}{l}\text { Running significantly improved creativity of school children compared to } \\
\text { regular physical education participants (F ratio }=17.00, p<0.001) \text { but had } \\
\text { no significant effect on classroom behaviour, perceptual functioning or } \\
\text { self-concept. }\end{array}$ \\
\hline Doyne et al. [118] & (1987) & USA & $\begin{array}{l}\text { Randomised } \\
\text { controlled trial }\end{array}$ & $\begin{array}{c}n=40 \text { women; all with a } \\
\text { diagnosis of minor or major } \\
\text { depression; mean age of } 28.52\end{array}$ & $\begin{array}{l}\text { Depression (Beck's Depression } \\
\text { Inventory, Hamilton Rating Scale } \\
\text { for Depression and Depression } \\
\text { Adjective Checklists) }\end{array}$ & $\begin{array}{l}\text { Impact of } 3 \text { runs per week on an } \\
\text { indoor track for } 8 \text { weeks on } \\
\text { depression in women diagnosed with } \\
\text { depression, compared to } 8 \text { weeks of } \\
\text { weight lifting vs. control } \\
\end{array}$ & $\begin{array}{l}\text { Running statistically and clinically significantly decreased depression } \\
\text { scores }\left(\mathrm{F}_{4,1,138)}=14.98, p<0.01\right) \text { relative to the wait-list control group, } \\
\text { with improvements reasonably well maintained at } 1 \text { year follow-up. }\end{array}$ \\
\hline $\begin{array}{l}\text { Fremont et al. } \\
\text { [119] }\end{array}$ & (1987) & USA & $\begin{array}{l}\text { Randomised } \\
\text { non-controlled } \\
\text { trial }\end{array}$ & $\begin{array}{c}n=49 ; 13 \text { males and } 36 \text { females; } \\
\text { aged 19-62 }\end{array}$ & $\begin{array}{l}\text { Depression, anxiety and mood } \\
\text { state (Beck's Depression } \\
\text { inventory, State-Trait Anxiety } \\
\text { Inventory and The Profile of } \\
\text { Mood States) } \\
\end{array}$ & $\begin{array}{l}\text { Impact of } 3 \text { runs per week for } 10 \\
\text { weeks on depression, anxiety and } \\
\text { mood vs. } 10 \text { weeks of counselling vs. } \\
10 \text { weeks of a combination of running } \\
\text { and counselling }\end{array}$ & $\begin{array}{l}\text { Depression, trait anxiety and state anxiety all decreased significantly } \\
\left.\left(\mathrm{F}_{(4,184)}\right) 50.3, p<0.0001\right),\left(\mathrm{F}_{(1,46)}=27.1, p<0.0001\right),\left(\mathrm{F}_{(1,46)}=21.9,\right. \\
p<0.0001) \text {, respectively), while mood improved significantly over the } 10 \\
\text { weeks }\left(\mathrm{F}_{(18,378)}=4.5, p<0.001\right) \text {. }\end{array}$ \\
\hline $\begin{array}{l}\text { Hannaford et al. } \\
{[120]}\end{array}$ & (1988) & USA & $\begin{array}{l}\text { Randomised } \\
\text { controlled trial }\end{array}$ & $\begin{array}{l}n=27 \text { male psychiatric patients } \\
\text { with major psychiatric disorders; } \\
\text { age range 25-60; } 9 \text { runners, } 9 \text { in } \\
\text { corrective therapy for } 8 \text { weeks } \\
\text { and } 9 \text { waiting list controls }\end{array}$ & $\begin{array}{l}\text { Depression and anxiety (Zung } \\
\text { Self Rating Depression Scale and } \\
\text { State Trait Anxiety Index) }\end{array}$ & $\begin{array}{l}\text { Impact of three } 30 \text {-min runs per week } \\
\text { for } 8 \text { weeks on depression and } \\
\text { anxiety in psychiatric patients with } \\
\text { major psychiatric disorders }\end{array}$ & $\begin{array}{l}\text { Significant reductions were observed in depression scores }\left(\mathrm{F}_{(2,23)}=3.61,\right. \\
p=0.043) \text { compared to the waiting list controls, and nonsigificant } \\
\text { reductions were observed in anxiety scores }\left(\mathrm{F}_{(2,23)}=1.085, p=0.354\right) \\
\text { compared to the waiting list control group. }\end{array}$ \\
\hline
\end{tabular}


Table 6. Cont.

\begin{tabular}{|c|c|c|c|c|c|c|c|}
\hline Author & Year & Country & Design & Population & $\begin{array}{l}\text { Mental Health Outcome } \\
\text { (Measurement) }\end{array}$ & Study Aim & Main Findings \\
\hline Long et al. [121] & (1988) & Canada & $\begin{array}{l}\text { Randomised } \\
\text { non-controlled } \\
\text { trial }\end{array}$ & $\begin{array}{l}n=39 \text { chronically stressed, } \\
\text { sedentary working women; mean } \\
\text { age } 40 ; 18 \text { joggers vs. } 21 \\
\text { relaxation intervention }\end{array}$ & $\begin{array}{l}\text { Stress, anxiety and self-efficacy } \\
\text { (Trait Anxiety Inventory, Sherer et } \\
\text { al.'s Inventory for Self-Efficacy } \\
\text { and a modified version of the } \\
\text { Ways of Coping Checklist) }\end{array}$ & $\begin{array}{l}\text { Impact of an 8-week running } \\
\text { programme consisting of a weekly } \\
\text { group session plus twice weekly solo } \\
\text { jogs on stress, anxiety and } \\
\text { self-efficacy }\end{array}$ & 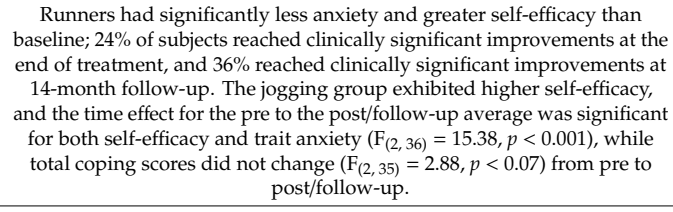 \\
\hline Simons et al. [122] & (1988) & USA & $\begin{array}{l}\text { Non-randomised } \\
\text { controlled trial }\end{array}$ & $\begin{array}{c}n=128 ; 53 \text { experimental subjects } \\
(24 \text { male, } 30 \text { female, mean age } \\
44.9) ; 75 \text { control subjects }(28 \text { male, } \\
47 \text { female, mean age of } 42.0)\end{array}$ & $\begin{array}{l}\text { Mood (Profile of Mood States, } \\
\text { Nowicki-Strickland } \\
\text { Internal-External Control Scale } \\
\text { for Adults and Marlowe-Crowne } \\
\text { Social Desirability Scale) } \\
\end{array}$ & $\begin{array}{l}\text { Impact of two } 30 \text { min walk/runs per } \\
\text { week for } 8 \text { weeks on mood, } \\
\text { compared to weekly } 30 \text {-min fitness } \\
\text { lecture for } 8 \text { weeks }\end{array}$ & 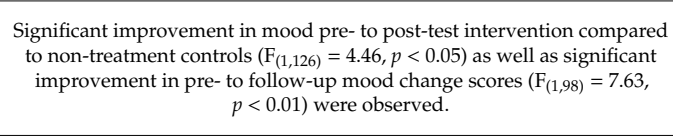 \\
\hline Moses et al. [123] & (1989) & UK & $\begin{array}{l}\text { Randomised } \\
\text { controlled trial }\end{array}$ & $\begin{array}{c}n=75 \text { sedentary adult volunteers; } \\
\text { mean age } 38.8 \text {; four 10-week } \\
\text { conditions: high-intensity aerobic } \\
\text { walk-jog programme }(n=18) ; \\
\text { moderate intensity walk-jog } \\
\text { programme }(n=19) ; \\
\text { attention-placebo including } \\
\text { strength, mobility and flexibility } \\
\text { exercises }(n=18) \text {; or waiting list } \\
\text { control }(n=20) .\end{array}$ & $\begin{array}{l}\text { Mood and mental well-being } \\
\text { (Profile of Mood States and the } \\
\text { Hospital Anxiety and Depression } \\
\text { Scale) }\end{array}$ & $\begin{array}{c}\text { Impact of varying intensity } 10 \text { week } \\
\text { walk-jog programmes on mood and } \\
\text { mental well-being }\end{array}$ & 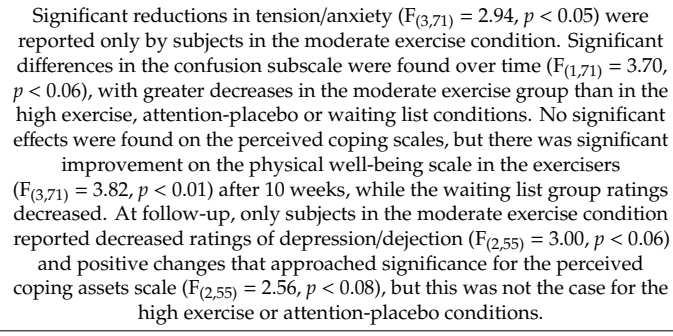 \\
\hline $\begin{array}{l}\text { Ossip-Klein et al. } \\
{[124]}\end{array}$ & (1989) & USA & $\begin{array}{l}\text { Randomised } \\
\text { controlled trial }\end{array}$ & $\begin{array}{c}n=32 \text { clinically depressed } \\
\text { women; mean age } 28.52\end{array}$ & $\begin{array}{l}\text { Self-concept (Beck Self-Concept } \\
\text { Test) }\end{array}$ & $\begin{array}{l}\text { Impact of running on an indoor track } \\
4 \text { times per week for } 8 \text { weeks on } \\
\text { self-concept in clinically depressed } \\
\text { women compared to weight lifting } 4 \\
\text { times weekly vs. a delayed treatment } \\
\text { (assessment only) control }\end{array}$ & $\begin{array}{l}\text { Self-concept significantly improved in the clinically depressed women } \\
\text { compared to controls }\left(\mathrm{F}_{(3,99)}=7.62, p<0.0001\right) \text {. Self-concept scores were } \\
\text { also significantly higher in those in the running condition compared to the } \\
\text { wait-list condition at post-treatment }\left(\mathrm{F}_{(\mathrm{F}), 233)}=4.69, \mathrm{~s}, p<0.05\right) \text {, with } \\
\text { improvements also reasonably well-maintained over time. }\end{array}$ \\
\hline Morris et al. [125] & (1990) & UK & $\begin{array}{l}\text { Pre-post study } \\
\text { with randomised } \\
\text { comparison }\end{array}$ & $\begin{array}{l}n=30 \text { male regular runners; } \\
\text { mean age } 37 ; 20 \text { participants } \\
\text { stopped running for } 2 \text { weeks vs. } \\
20 \text { continued running as normal }\end{array}$ & $\begin{array}{l}\text { Anxiety and depression (General } \\
\text { Health Questionnaire and short } \\
\text { forms of the Zung Anxiety and } \\
\text { Zung Depression scales) }\end{array}$ & $\begin{array}{l}\text { Impact of stopping running for } 2 \\
\text { weeks on anxiety and depression }\end{array}$ & 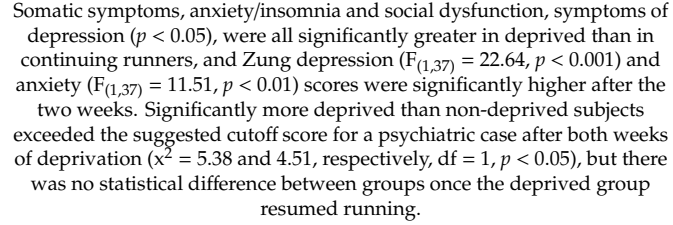 \\
\hline
\end{tabular}


Table 6. Cont

\begin{tabular}{|c|c|c|c|c|c|c|c|}
\hline Author & Year & Country & Design & Population & $\begin{array}{c}\text { Mental Health Outcome } \\
\text { (Measurement) }\end{array}$ & Study Aim & Main Findings \\
\hline $\begin{array}{l}\text { Friedman et al. } \\
{[126]}\end{array}$ & (1991) & USA & $\begin{array}{l}\text { Randomised } \\
\text { controlled trial }\end{array}$ & $\begin{array}{c}n=387 \text { students; } 177 \text { males and } \\
188 \text { females; mean age } 20 ; \\
84 \text { joggers, } 96 \text { relaxation, } 100 \\
\text { group interaction and } 107 \\
\text { lecture-control }\end{array}$ & $\begin{array}{l}\text { Stress and mood (Profile of Mood } \\
\text { States and Bem Sex Role } \\
\text { Inventory) }\end{array}$ & $\begin{array}{l}\text { Impact of } 12 \text { weeks of jogging on } \\
\text { stress and mood }\end{array}$ & 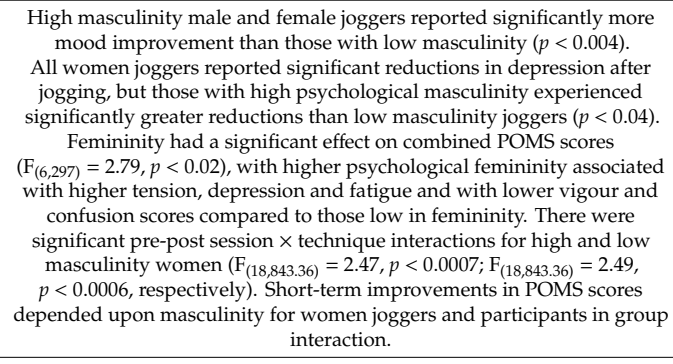 \\
\hline $\begin{array}{l}\text { Williams et al. } \\
{[127]}\end{array}$ & (1991) & USA & $\begin{array}{c}\text { Pre-post } \\
\text { non-controlled } \\
\text { within subject } \\
\text { design }\end{array}$ & $\begin{aligned} n= & 10 \text { moderately trained male } \\
& \text { runners; mean age } 25.6\end{aligned}$ & Mood (Profile of Mood States) & $\begin{array}{l}\text { Impact of } 4 \text { weeks of treadmill } \\
\text { running } 5 \text { times per week at set paces } \\
\text { reflecting } 50,60 \text { and } 70 \% \mathrm{VO}_{2} \text { max on } \\
\text { mood }\end{array}$ & $\begin{array}{l}\text { Regarding within-subject data, an increase in mean } \mathrm{VO}_{2} \text { was associated } \\
\text { with a significant increase in total mood disturbance }(\mathrm{r}=0.88,, p<0.01) \\
\text { while running at a pace with more economical values was associated with } \\
\text { more positive mental health profiles. However, when considered as a } \\
\text { group, there was no relationship between running efficiency in moderately } \\
\text { trained male runners and total mood disturbance. }\end{array}$ \\
\hline Kerr et al. [128] & (1993) & Holland & $\begin{array}{c}\text { Pre-post } \\
\text { non-controlled }\end{array}$ & $\begin{array}{c}n=32 \text { regular exercising } \\
\text { university students (18 males and } \\
14 \text { females) aged } 18-22\end{array}$ & $\begin{array}{l}\text { Mood (Stress-Arousal Checklist } \\
\text { and Telic State Measure) }\end{array}$ & $\begin{array}{l}\text { Impact of a weekly 40-min fixed } \\
\text { distance run (5 km for females, } 6.6 \\
\text { km for maless through a wooded area } \\
\text { for } 7 \text { weeks on mood }\end{array}$ & 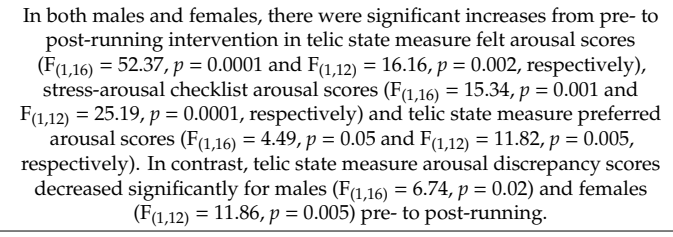 \\
\hline Long [129] & (1993) & Canada & $\begin{array}{l}\text { Randomised } \\
\text { controlled trial }\end{array}$ & $\begin{array}{c}n=35 ; 14 \text { males and } 21 \text { females; } \\
\text { mean age } 35.6 ; 12 \text { runners, } \\
9 \text { stress inoculation and } 14 \\
\text { wait-list control }\end{array}$ & $\begin{array}{l}\text { Anxiety and stress (Cornell } \\
\text { Medical Symptom Checklist) }\end{array}$ & $\begin{array}{l}\text { Impact of } 3 \text { runs per week for } 10 \\
\text { weeks on anxiety and stress }\end{array}$ & $\begin{array}{l}\text { Although the exercise group was more likely to report using exercise to } \\
\text { cope with stress, there was no significiant differences found between } \\
\text { groups on stress or coping classifications. There was also no significant } \\
\text { difference in scores of the Cornell Medical Symptom Checklist between the } \\
\text { running group and the stress inoculation treatment groups ( } \mathrm{F}<1 ; \mathrm{M}=87.4 \\
\text { vs. } \mathrm{M}=86.2 \text {, respectively). }\end{array}$ \\
\hline $\begin{array}{l}\text { Berger and } \\
\text { Friedman [130] }\end{array}$ & (1998) & USA & $\begin{array}{l}\text { Randomised } \\
\text { controlled trial }\end{array}$ & $\begin{array}{l}n=387 \text { undergraduate college } \\
\text { students; } 117 \text { males and } 188 \\
\text { females; mean age 20.0; } 84 \\
\text { joggers vs. } 96 \text { relaxation response } \\
\text { vs. } 100 \text { in discussion groups vs. } \\
107 \text { in the control group }\end{array}$ & $\begin{array}{l}\text { Stress and mood (Profile of Mood } \\
\text { States) }\end{array}$ & $\begin{array}{l}\text { Impact of three jogs per week for a } \\
\text { minimum of } 20 \text { min over } 12 \text { weeks on } \\
\text { stress and mood }\end{array}$ & $\begin{array}{l}\text { Jogging was significantly more effective in reducing stress than the control } \\
\text { activity }\left(\mathrm{F}_{(18,280)}=1.79 \text { to } 1.85, p<0.03\right) \text {, and joggers reported larger and } \\
\text { morre numerous reductions in tension, depression and anger than the } \\
\text { control group; however, changes in vigour, fatigue and confusion were } \\
\text { sporadic. There were no long-term benefits observed. }\end{array}$ \\
\hline $\begin{array}{l}\text { Berger and Owen } \\
{[131]}\end{array}$ & (1998) & USA & $\begin{array}{l}\text { Pre-post with } \\
\text { comparison }\end{array}$ & $\begin{array}{l}n=91 \text { college students; } n=67 \text { in } \\
\text { weekly walking/jogging ( } 32 \text { males } \\
\text { and } 35 \text { females) vs. } n=24 \text { in a } \\
\text { weekly health science class } \\
(9 \text { males and } 15 \text { females) }\end{array}$ & $\begin{array}{l}\text { Mood and anxiety (Profile of } \\
\text { Mood States and State-Trait } \\
\text { Anxiety Inventory) }\end{array}$ & $\begin{array}{l}\text { Impact of twice weekly } \\
\text { walking/jogging for 14 weeks on } \\
\text { mood and anxiety }\end{array}$ & 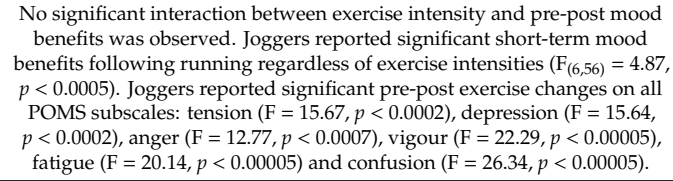 \\
\hline
\end{tabular}


Table 6. Cont.

\begin{tabular}{|c|c|c|c|c|c|c|c|}
\hline Author & Year & Country & Design & Population & $\begin{array}{l}\text { Mental Health Outcome } \\
\text { (Measurement) }\end{array}$ & Study Aim & Main Findings \\
\hline Szabo et al. [132] & (1998) & UK & $\begin{array}{l}\text { Pre-post } \\
\text { non-controlled } \\
\text { observational } \\
\text { cohort study }\end{array}$ & $\begin{array}{l}n=40 \text { members of an amateur } \\
\text { running club; } 30 \text { males, mean age } \\
40.5, \text { and } 10 \text { females, mean age } 37\end{array}$ & $\begin{array}{l}\text { Anxiety and mood, i.e., } \\
\text { exhaustion, tranquillity, positive } \\
\text { engagement and revitalization } \\
\text { (Commitment to running scale, } \\
\text { Exercise-induced Feeling } \\
\text { Inventory and Spielberger State } \\
\text { Anxiety Inventory) }\end{array}$ & $\begin{array}{l}\text { Impact of running vs. non-running } \\
\text { days on anxiety and mood over } 21 \\
\text { consecutive days }\end{array}$ & $\begin{array}{l}\text { Reported differences (effect sizes ranging from } 0.07 \text { to } 0.56 \text {, all } p<0.05 \text { all } \text { all } \\
\text { favour running days over non-running days, concluding that, on running } \\
\text { days, runners experienced less anxiety }\left(\mathrm{F}_{(1,38)}=5.22, p<0.03\right) \text { and better } \\
\left.\text { subscales of mood: exhaustion } \mathrm{F}_{(1,138)}=4.34, p<0.04\right) \text {, tranquillitity } \\
\left(\mathrm{F}_{(1,38)}=5.56, p<0.02\right) \text {, revitalisation }\left(\mathrm{F}_{(1,38)}=18.32, p<0.001\right) \text { and } \\
\text { positive engagement }\left(\mathrm{F}_{(1,38)}=11.79, p<0.001\right) \text {. }\end{array}$ \\
\hline $\begin{array}{l}\text { Broman-Fulks et al. } \\
\text { [133] }\end{array}$ & (2004) & USA & $\begin{array}{l}\text { Randomised } \\
\text { non-controlled } \\
\text { trial }\end{array}$ & $\begin{array}{l}n=54 \text { participants with elevated } \\
\text { anxiety sensitivity scores; } \\
13 \text { males and } 41 \text { females; mean } \\
\text { age } 21.17 ; 29 \text { high-intensity } \\
\text { aerobic exercisers vs. } 25 \\
\text { low-intensity aerobic exercisers }\end{array}$ & $\begin{array}{l}\text { Anxiety sensitivity (Anxiety } \\
\text { Sensitivity Index, State-trait } \\
\text { Anxiety Inventory and Body } \\
\text { Sensations Questionnaire) }\end{array}$ & $\begin{array}{l}\text { Impact of six 20-min treadmill } \\
\text { sessions of either high/low-intensity } \\
\text { aerobic exercise across } 2 \text { weeks on } \\
\text { anxiety sensitivity in participants } \\
\text { with elevated anxiety } \\
\text { sensitivity scores }\end{array}$ &  \\
\hline $\begin{array}{l}\text { Haffmans et al. } \\
{[134]}\end{array}$ & (2006) & Holland & $\begin{array}{l}\text { Randomised } \\
\text { controlled trial }\end{array}$ & $\begin{array}{l}n=60 \text { psychiatric patients all } \\
\text { suffering from a depressive } \\
\text { disorder; } 19 \text { males and } 41 \text { females; } \\
\text { mean age } 39 ; 20 \text { runners vs. } 21 \text { in } \\
\text { physiotherapy training vs. } \\
19 \text { controls }\end{array}$ & $\begin{array}{l}\text { Depression and self-efficacy } \\
\text { (Hamilton Rating Scale for } \\
\text { Depression, Becks Depression } \\
\text { Inventory, Self-Efficacy Scale and } \\
\text { Physical Self-Efficacy Scale) }\end{array}$ & $\begin{array}{l}\text { Impact of running therapy for } 3 \text { days } \\
\text { per week for } 12 \text { weeks on depression } \\
\text { and selffe-fficacy in psychiatric } \\
\text { patients all suffering from depression }\end{array}$ & $\begin{array}{l}\text { While after } 6 \text { weeks of running, self-efficacy was significantly higher } \\
(p=0.03) \text {, after the full } 12 \text { weeks of running, there was no significant } \\
\text { difference in depression (26.7 to } 25.5, n . s .) \text { or self-efficacy (46.6 to } 49.1, n \text {..s.) } \\
\text { scores from baseline. }\end{array}$ \\
\hline $\begin{array}{l}\text { Thornton et al. } \\
\text { [135] }\end{array}$ & (2008) & USA & $\begin{array}{c}\text { Repeated } \\
\text { measures design }\end{array}$ & $n=50$ runners over age 18 & Anxiety (Beck Anxiety Inventory) & $\begin{array}{l}\text { The relationship between anxiety and } \\
\text { marathon }\end{array}$ & $\begin{array}{l}\text { Marathon training decreased Beck Anxiety Inventory scores ( } 0.9 \text { ) initially } \\
\text { from baseline pre-training levels compared to } 2 \text { months prior to marathon } \\
\text { day }(0.7 ; 772 \% \text { had no change from baseline, } 22 \% \text { were less anxious and } 6 \% \\
\text { were more anxious). However, anxiety scores increased as race day } \\
\text { approached: at } 1 \text { month hrior to race day } 1(1.4 ; 46 \% \text { had no change from } \\
\text { baseline, } 19 \% \text { were less anxious and } 35 \% \text { were more anxious than baseline) } \\
\text { and } 1 \text { week prior to racec (2.6; } 22 \% \text { had no change from baseline, } 14 \% \text { were } \\
\text { less anxious and } 64 \% \text { were more anxious than baseline, respectively). }\end{array}$ \\
\hline Scholz et al. [136] & (2008) & Switzerland & $\begin{array}{c}\text { Pre-post } \\
\text { non-controlled } \\
\text { non-experimental } \\
\text { longitudinal study }\end{array}$ & $\begin{array}{c}n=30 \text { untrained participants; } \\
4 \text { males and } 26 \text { females; mean age } \\
41.2\end{array}$ & $\begin{array}{l}\text { Self-efficacy (4-part } \\
\text { author-created measurement) }\end{array}$ & $\begin{array}{l}\text { Impact of a 1-year marathon training } \\
\text { programme on self-efficacy }\end{array}$ & $\begin{array}{l}\text { The trend between running and self-efficacy had substantial correlation } \\
\text { but was not significant. No statically significant differences was observed } \\
\text { in the baseline level, trend or fluctuation of self-efficacy between the } \\
\text { participants who successfully completed the marathon and those who did } \\
\text { not, but the baseline level of self-efficacy was positively associated with } \\
\text { the baseline level in running (correlation analyses }=0.27 ; p<0.05 ; 95 \% \\
\mathrm{CI}=0.00 ; 0.53) \text { and fluctuation in self-efficacy correlated positively with } \\
\text { fluctuation in running (0.39; } p<0.05 ; 95 \% \mathrm{CI}=0.03 ; 0.74) \text {. As this was a } \\
\text { non-experimental longitudinal study, no causal statements can be drawn. }\end{array}$ \\
\hline Kalak et al. [137] & (2012) & Switzerland & $\begin{array}{l}\text { Randomised } \\
\text { controlled trial }\end{array}$ & $\begin{array}{c}n=51 \text { adolescents; } 24 \text { males and } \\
27 \text { females; mean age } 18.3 ; \\
27 \text { runners vs. } 24 \text { controls }\end{array}$ & $\begin{array}{l}\text { Mood and stress (A-a daily mood } \\
\text { log, a questionnaire assessing } \\
\text { positive and negative comping } \\
\text { strategies, and Perceived } \\
\text { Stress Scale) }\end{array}$ & $\begin{array}{l}\text { Impact of daily } 30 \text {-min morning runs } \\
\text { on weekdays for } 3 \text { weeks (i.e., } 3 \times 5 \\
\text { runs) on stress and mood }\end{array}$ & $\begin{array}{l}\text { Perceived stress did not differ significantly between running and control } \\
\text { groups over time }\left(\mathrm{F}_{(1,49)}=1.71, \mathrm{n}^{2}=0.034, n, \mathrm{n} . \mathrm{s}\right) \text {, while mood in the } \\
\text { morning increased significantly over time in the running group compared } \\
\left.\text { with controls } \mathrm{F}_{(5,2,25)}=16.08, \mathrm{n}^{2}=0.247, p<0.05\right) \text {. However, irrespective } \\
\text { of group, mood in the evening improved, and there was no significant } \\
\text { difference of mood in the evening between groups. }\end{array}$ \\
\hline Inoue et al. [138] & (2013) & USA & $\begin{array}{c}\text { Pre-post } \\
\text { non-controlled }\end{array}$ & $\begin{array}{c}n=148 \text { homeless people; } \\
134 \text { males and } 14 \text { females; } \\
\text { mean age } 29.9\end{array}$ & $\begin{array}{l}\text { Self-sufficiency (author-created } \\
\text { scale) }\end{array}$ & $\begin{array}{l}\text { Impact of } 10 \text { organised runs on } \\
\text { self-sufficiency in homeless people }\end{array}$ & $\begin{array}{l}\text { Running involvement had a significant positive correlation with perceived } \\
\text { self-sufficiency }(\mathrm{r}=0.30, p<0.01 \text {. Results suggested that participants } \\
\text { gained higher levels of perceived self-sufficiency as they became more } \\
\text { involved with running during the program }(\mathrm{F}=3.39, p<0.01 \text {, } \\
\text { Adjusted } 2=0.08 \text { ) and increases in running involvement were the sole } \\
\text { significant predictor of the outcome }(\beta=0.29, \mathrm{t}=3.57, p<0.01) \text {. }\end{array}$ \\
\hline Samson et al. [76] & (2013) & USA & $\begin{array}{c}\text { Pre-post } \\
\text { non-controlled }\end{array}$ & $\begin{array}{l}n=39 \text { university students who all } \\
\text { had running experience; } 11 \text { males } \\
\text { and } 28 \text { females; mean age } 20.5\end{array}$ & $\begin{array}{l}\text { General affect and self-efficacy } \\
\text { (Positive and Negative Affect } \\
\text { Scale and author-created } \\
\text { measurements for self-efficacy) }\end{array}$ & $\begin{array}{l}\text { Impact of a 15-week marathon } \\
\text { training program of } 3 \text { group training } \\
\text { days per week and one run of } 8-20 \\
\text { miles on the weekend on general } \\
\text { affect and self-efficacy }\end{array}$ & $\begin{array}{l}\text { Self-efficacy significantly increased over the training programme } \\
\left(\mathrm{F}_{(12,444)}=5.81, p<0.01\right), \text { but there was a significant decrease of positive } \\
\text { affect over time }\left(\mathrm{F}_{(12,2,44)}=8.35, p<0.01\right) \text { and no significant change was } \\
\text { found for negative affect over the programme. }\end{array}$ \\
\hline
\end{tabular}


Table 6. Cont

\begin{tabular}{|c|c|c|c|c|c|c|c|}
\hline Author & Year & Country & Design & Population & $\begin{array}{l}\text { Mental Health Outcome } \\
\text { (Measurement) }\end{array}$ & Study Aim & Main Findings \\
\hline Doose et al. [139] & (2015) & Germany & $\begin{array}{l}\text { Randomised } \\
\text { controlled trial }\end{array}$ & $\begin{array}{c}n=46 \text { outpatients diagnosed } \\
\text { with mild to severe depression; } \\
\text { aged } 18-65 ; 30 \text { walker/runner vs. } \\
16 \text { controls }\end{array}$ & $\begin{array}{l}\text { Depression (Hamilton Rating } \\
\text { Scale and Beck Depression } \\
\text { Inventory) }\end{array}$ & $\begin{array}{l}\text { Impact of group walking/running } 3 \\
\text { times per week for } 8 \text { weeks on } \\
\text { depression }\end{array}$ & $\begin{array}{l}\text { Depression clinically significantly decreased on the Hamilton Rating Scale } \\
\text { (Cohen's } d=1.8 ; \text { mean change }=8.24 ; p=<0.0001 \text { ), and while there were } \\
\text { reductions, they were without clinical significance (Cohen's } d=0.50 ; \\
\text { mean change }=4.66 ; p=0.09 \text { ) in the Becks Depression Inventory scores. }\end{array}$ \\
\hline $\begin{array}{c}\text { Von Haaren et al. } \\
\text { [140] }\end{array}$ & (2015) & Germany & $\begin{array}{l}\text { Randomised } \\
\text { controlled trial, } \\
\text { within subject } \\
\text { design }\end{array}$ & $\begin{array}{c}n=61 \text { inactive male university } \\
\text { students; mean age 21.4 }\end{array}$ & $\begin{array}{l}\text { Stress and mood (a shorten mood } \\
\text { scale based on the } \\
\text { Multidimensional Mood } \\
\text { Questionnaire and a one-item test } \\
\text { for perceived control and stress) }\end{array}$ & $\begin{array}{l}\text { Impact of a 20-week running training } \\
\text { course on stress and mood during } \\
\text { academic examinations, compared to } \\
\text { waiting list controls }\end{array}$ & $\begin{array}{l}\text { Significant emotional stress reactivity was observed in both groups during } \\
\text { academic assessment episodess participants in aerobic training showed } \\
\text { lower emotional stress reactivity compared with the control participants } \\
\text { after the 20-week training programme, with perceived stress of the aerobic } \\
\text { group remaining similar during both exam periods (2.27 to } 2.24 \text { ) while it } \\
\text { increased further in the control group (2.43 to } 2.51) \text {. }\end{array}$ \\
\hline Kahan et al. [141] & (2018) & USA & $\begin{array}{l}\text { Pre-post with } \\
\text { comparison }\end{array}$ & $\begin{array}{c}n=11 \text { children; } 9 \text { males and } 2 \\
\text { females; aged } 9 \text { and } 10\end{array}$ & $\begin{array}{l}\text { Self-esteem and self-efficacy } \\
\text { (50-item, author-created } \\
\text { questionnaire) }\end{array}$ & $\begin{array}{l}\text { Impact of } 20 \text { running sessions } \\
\text { alternating between game vs. lap } \\
\text { running on self-esteem and } \\
\text { self-efficacy in children }\end{array}$ & $\begin{array}{l}\text { Means for self-esteem and task-efficacy were } 3.63 \text { and } 4.16, \text { respectively, } \\
\text { on a } 5 \text {-point scale, while the mean for task-efficacy was s.16 on a } 5 \text {-point } \\
\text { scale, and high inherent-interest participants (i.e., higher } \\
\text { moderate-vigorous physical activity in the running laps condition) had } \\
\text { statistically significant higher scores than low inherent-interest } \\
\text { participants on recognition }(p=0.01) \text {, ego orientation ( } p=0.03) \text { and } \\
\text { expectancy beliefs }(p=0.03) \text { subscales. There were no direct comparisons } \\
\text { of self-esteem and self-efficacy in game vs. lap running. }\end{array}$ \\
\hline Keating et al. [142] & (2018) & Canada & $\begin{array}{c}\text { Pre-post } \\
\text { non-controlled }\end{array}$ & $\begin{array}{l}n=46 \text { participants with complex } \\
\text { mood disorders; } 11 \text { males and } 35 \\
\text { females; } 29 \text { youths (mean age } \\
\text { 22.1) and } 17 \text { adults } \\
\text { (mean age 45.2) }\end{array}$ & $\begin{array}{l}\text { Stress, anxiety and depression } \\
\text { (Cohen's Perceived Stress Scale, } \\
\text { Becks Depression Inventory, } \\
\text { Becks Anxiety Inventory and } \\
\text { Short Form Survey) }\end{array}$ & $\begin{array}{l}\text { Impact of } 12 \text { weeks of twice weekly } \\
\text { running in a group setting that offers } \\
\text { social support supervised by clinical } \\
\text { professionals on stress, anxiety and } \\
\text { depression }\end{array}$ &  \\
\hline Nezlek et al. [143] & (2018) & Poland & $\begin{array}{c}\text { Pre-post } \\
\text { observational } \\
\text { cohort study over } \\
3 \text { months with no } \\
\text { control }\end{array}$ & $\begin{array}{l}n=244 \text { recreational runners; } 127 \\
\text { males and } 117 \text { females; mean age } \\
\quad 32.5\end{array}$ & $\begin{array}{l}\text { Psychological well-being, } \\
\text { self-esteem, self-efficacy and } \\
\text { affect (Rosenenber Self-esteem } \\
\text { Scale, Satisfaction with Life Scale, } \\
\text { and a circumplex model that } \\
\text { distinguishes the valence and } \\
\text { arousal of affect) }\end{array}$ & $\begin{array}{l}\text { Impact of } 3 \text { months of self-prescribed } \\
\text { running on psychological well-being, } \\
\text { self-esteem, self-efficacy and affect }\end{array}$ &  \\
\hline $\begin{array}{l}\text { Kruisdijk et al. } \\
\text { [144] }\end{array}$ & (2019) & Holland & $\begin{array}{l}\text { Randomised } \\
\text { controlled trial }\end{array}$ & $\begin{array}{l}n=48 \text { participants with major } \\
\text { depressive disorder; mean age } \\
42.6 ; 25 \text { runner-walkers vs. } 23 \\
\text { controls }\end{array}$ & $\begin{array}{l}\text { Depression (Hamilton } \\
\text { Depression Scale) }\end{array}$ & $\begin{array}{l}\text { Impact of } 6 \text { months of } \\
\text { running-walking for one hour twice a } \\
\text { week on depression in subjects with } \\
\text { major depressive disorder }\end{array}$ & $\begin{array}{l}\text { No significant difference or effect on depression in favour of the } \\
\text { intervention group (Cohen's } \mathrm{d}<0.2, \mathrm{~F}=0.13, p=0.73) \text { with only } 9 \\
\text { participants }(19 \%) \text { completing the study was found, with low statistical } \\
\text { power and lack of follow-up at six and } 12 \text { months. }\end{array}$ \\
\hline
\end{tabular}


A number of studies looked at specific populations. One investigated the impact of 10 organised runs on homeless people and found significant positive correlation with perceived self-sufficiency [138]. Two investigated the effects in children and found that running significantly improved creativity and higher self-esteem subscales $[117,141]$. Three looked at marathon training programmes: one found a positive correlation between the trend in running and self-efficacy but was not significant [136], while another found a significant increase in self-efficacy over the programme [76]. The remaining study used participants who were already self-enrolled in a marathon, and researchers found that, while anxiety decreased initially during training, anxiety increased as marathon day approached [135].

Nine studies used subjects with known psychiatric disorders and found that longer-term interventions generally improved markers of mental health in psychiatric populations, particularly markers of depression [112,113,118,120,124,133,134,142,144]. Running interventions from 2 to 12 weeks all resulted in significant positive effects on mental health $[112,118,120,124,133,142,144]$. While an anti-depressive effect of exercise was apparent in patients with minor to moderate psychiatric problems, one study found that this was not reflected in patients with major depressive disorder due to issues with compliance and motivation towards the intervention [144].

\section{Summary of Longer-Term Interventions}

Overall, running interventions of 2-20 weeks generally show improved markers of a range of mental health outcomes compared to non-running controls, including mental health outcomes in psychiatric and homeless populations. The risk of longer-term running interventions on adverse mental health outcomes remains unclear.

\subsection{Summary of Key Findings}

The key findings of the each of the three categories of studies are summarised in Table 7.

Table 7. Summary of key findings within each of the three categories.

\begin{tabular}{lcc}
\hline Study Type & Number of Studies & Summary of Evidence \\
\hline Cross-sectional & 47 studies & $\begin{array}{c}\text { Consistent evidence was found for a positive association between mental health and } \\
\text { habitual or long-term recreational running compared to non-runners. In contrast, } \\
\text { there was evidence that high or extreme levels of running were associated with } \\
\text { markers of running ill-health compared to levels of moderate running. }\end{array}$ \\
\hline Acute: single/double/triple bout & 35 studies & $\begin{array}{c}\text { Overall, these studies suggest that acute bouts of running can improve mental health } \\
\text { and that the type of running can lead to differential effects. Evidence suggests that } \\
\text { acute bouts of treadmill, track, outdoor and social running (2.5-20 km and 10-60 min) } \\
\text { all result in improved mental health outcomes. There were few differences between } \\
\text { high and low intensities. Studies consistently show that any running improves } \\
\text { acute/short-term mood markers but that lack of inactive comparisons limits the } \\
\text { strength of evidence. Little variation in the demographics of participants and small } \\
\text { sample sizes limit generalizability and precision of findings. }\end{array}$ \\
\hline Interventions (2 weeks or more) & 34 studies & $\begin{array}{c}\text { Overall, running interventions of 2-20 weeks generally show improved markers of a } \\
\text { range of mental health outcomes compared to non-running controls, including mental } \\
\text { health outcomes in psychiatric and homeless populations. The risk of longer-term } \\
\text { running interventions on adverse mental health outcomes remains unclear. }\end{array}$ \\
\hline
\end{tabular}

\subsection{Evidence Gaps}

As well as reporting the available evidence, this review also aimed to identify key gaps in the evidence base for running and mental health. Consideration of sample demographics in the $n=116$ included studies resulted in the following gaps being identified:

- lack of studies in those aged under 18 (Only four acute bout studies $[89,95,107,108]$ and two longer term interventions $[117,141]$ looked directly at children under age 15 , while a further 2 studies looked specifically at adolescents [70,137]);

- lack of studies in those aged over 45;

- lack of gender-specific approaches;

- few studies investigating clinical populations; and

- limited diversity in patient demographics. 


\section{Discussion}

\subsection{Principal Findings}

There is a growing body of literature exploring the relationships of running on certain mental health outcomes. There were variations in methods and outcomes studied, but there were similar overall beneficial trends. Generally, evidence supported positive effects of a range of lengths and intensities of running on mental health. However, there was limited diversity in participant demographics. Attribution was also compromised by the limited number of studies with comparisons/control groups. Synthesis of quantified effects is made challenging by large variations in reporting methods. Consistency and appropriateness of mental health measures was also varied throughout the literature.

The review identified a smaller evidence-base focused on clinical populations. Behaviour change and compliance can be challenging in populations with clinical depressive disorders [145], and there is limited evidence regarding the long-term impact of PA in the treatment of depression $[7,146,147]$. Further investigations of the effects of running in populations with prior diagnoses of mental health disorders may help to address the global burden of mental illness.

\subsection{Plausible Explanations for Findings}

Our findings suggest that, throughout cross-sectional evidence, acute bouts of running and longer-term running interventions are associated with improvements in a range of mental health outcomes. This is likely explained by running supplying a sufficient dose of moderate to vigorous PA to stimulate the known mental health benefits associated with PA. These benefits are thought to be mediated by neurobiological, psychosocial and behavioural mechanisms, all of which an effective running intervention of any genre has the potential to influence [148]. The differential effects of these mechanisms remain unclear and may explain the variation in findings by running duration, intensity, setting, and social or individual participation.

\subsection{Comparison to Literature}

This review does not present running and mental health as a novel idea. As early as 1979, scholars discussed the relationship between psychotherapy and running [149]. An early review by Vezina et al. (1980) reported that regular running causes positive mood changes, increases self-esteem and decreases anxiety [150]. Another review by Hinkle (1992) found positive psychological effects in both adults and children including reductions in depressive mood and anxiety, and enhanced self-esteem [151]. However, a review by Weinstein et al. (1983) found that the volume of literature examining running and depression was scarce, and while running appeared to improve a sense of well-being, there was minimal evidence to strongly support reductions in depression and anxiety [152].

Studies from 1986 [153] and 1991 [154] warned that long-distance running had the potential to trigger development of eating disorders in people who were psychologically or biologically at risk. Early research also highlighted that runners should be aware of the possibility of addiction [155] and that women may be linked more strongly to negative addiction than men [156].

This review agrees with these earlier findings but is the first to use systematic scoping review methods. This means that it presents a transparent search and inclusion strategy and is less prone to bias in terms of included studies and resulting findings. As such, this review has contributed to the evidence base by demonstrating that the weight of evidence up to 2019 favours positive mental health relationships with running.

\subsection{Strengths and Limitations}

The authors acknowledge the limitation that this review was designed to assess the behaviour of running but that there are fields of studies including treadmill-based exercise which our review may not have picked up. However, the strength of this review is that the review does not focus on laboratory-based exercise but instead on what a healthcare professional may recommend to a free-living 
patient or the general public for mental health benefits. However, subjective measures of running intensity were not considered in detail, which may impact the conclusions of the review. The authors acknowledge that the results were not separated by means of running type due to the method of prioritization used to report the results, and thus, this remains a research gap. As with any scoping review, it is possible that the search and inclusion strategy led to omission of some key research.

Synthesis of quantified effects was also made challenging by the large range of reporting methods used within the studies. This scoping review did not attempt to undertake quality appraisal of the included studies. The wide range of study designs and methods included within the review does not allow a statistical synthesis of the effectiveness of the studies.

\subsection{Implications}

Pharmacological management is often used as a first-line of defence for mental health disorders [157]; however, it is not always effective due to poor adherence and relapse [158]. Ineffective management adds to the global burden of poor mental health [159]' With increasing pressures on healthcare budgets, PA offers an augmentative therapeutic option for mental health management [160]. It is likely that using a cost-effective therapy such as running to improve mental health would prove economical as well. An integrated lifestyle intervention (i.e., iterative process) may be more feasible than a single add-on exercise intervention (i.e., addition of an individual behaviour) for patients with major depressive disorder who are deemed suitable for running therapy by clinicians.

This review presents the effects of running on mental health and can inform healthcare professionals and psychologists who advise on management of mental health conditions. The authors' interpretation of the evidence base is that, with appropriate clinical judgement, practitioners may identify patients with an interest in running or previous history of running as an ideal candidate for running as a form of psychotherapy. Findings from this review indicate that characteristics of running to be recommended may include self-pacing, distance and time feasibility to the individual, and being within the lactate threshold. There were consistent trends within findings despite a variety of running interventions, which suggest that it would be appropriate to recommend track running, outdoor urban and rural running, and treadmill running to improve mental health. However, a large number of studies used healthy, active college-aged participants, which may limit the relevance of these recommendations to other population groups. It is acknowledged that running will not be a suitable recommendation for everyone and that prescription of running is not as simple as just instructing people to run; it will require clinical expertise with regard to mental health in the way it is prescribed [161].

\subsection{Future Research}

This review identifies research gaps regarding patient demographics, but we have further recommendations about increasing sample sizes, quantitative study design and more coherent mental health outcomes. There was great variability in mental health outcome measures, particularly within the acute bout studies, where short-term measures of mental health could have equally been defined as mood and affect. We recommend that future research seeks more clarity on appropriate outcome measures. A comparison of types, settings and intensities of running is needed to better inform running and mental health recommendations.

Recommendations for future research include addressing the effect of running on mental health of those under 18, those over 50s and clinical populations. A meta-analysis of the subset of study types such as interventions should be carried out. While the appropriateness of running interventions in those over 50 may be questioned, there is evidence that older adults do also benefit from the anti-depressive effect of exercise [162]. We know that children running can be used as a population intervention, for example, in "The Daily Mile" [163], which signifies the importance of addressing this gap around the mental health impact of running in those under 18. Future systematic reviews and meta-analyses are needed to quantify the benefits of running on specific outcomes. 


\section{Conclusions}

This review is the most recent to comprehensively report the breadth of literature on the relationship between running and mental health. We conclude that running has important positive implications for mental health, particularly depression and anxiety disorders, but synthesis of quantified effects is made challenging by variation in reporting methods and remains a gap. This scoping review may have consequences for researchers, practitioners and relevant organisations and may inform the practice of healthcare professionals. Knowledge gaps concerning running on the mental health of children, older adults and clinical populations provide guidance for future research

Supplementary Materials: The following are available online at http://www.mdpi.com/1660-4601/17/21/8059/s1, Table S1: Narrative description of findings of the 47 cross-sectional studies. Table S2-S4: Narrative description of findings of the 35 studies with an acute bout of running. Table S5: Narrative description of findings of the 34 studies with a longer-term intervention of running.

Author Contributions: P.K., J.R. and F.O. conceived the study. P.K., C.W. and F.O. designed the search strategy. F.O. conducted searching of databases. J.C., P.K., F.O. and C.W. screened the records. F.O. and P.K. screened the full texts. F.O. completed all data extraction, and J.R. conducted quality checks. F.O. drafted the full manuscript, and all authors reviewed and approved final submission. All authors have read and agreed to the published version of the manuscript.

Funding: This research received no external funding.

Acknowledgments: The authors would like to thank a number of people for their assistance during the scoping review: Thelma Dugmore for her support and administration help within the Edinburgh University Physical Activity for Health Research Centre (PAHRC), Marshall Dozier for her assistance setting up a Covidence account for the project to run through, all the staff at PAHRC for being so welcoming and interested in the project and, finally, Colin Oswald who was a source of great encouragement and support throughout the project.

Conflicts of Interest: The authors declare no conflict of interest.

\section{Appendix A}

Table A1. Preferred Reporting Items for Systematic reviews and Meta-Analyses extension for Scoping Reviews (PRISMA-ScR) Checklist [18].

\begin{tabular}{|c|c|c|c|}
\hline Section & Item & PRISMA-ScR CHECKLIST ITEM & $\begin{array}{l}\text { Reported on Page } \\
\text { Number }\end{array}$ \\
\hline \multicolumn{4}{|c|}{ Title } \\
\hline Title & 1 & Identify the report as a scoping review. & 1 \\
\hline \multicolumn{4}{|c|}{ Abstract } \\
\hline Structured summary & 2 & $\begin{array}{l}\text { Provide a structured summary that includes (as applicable) } \\
\text { background, objectives, eligibility criteria, sources of evidence, } \\
\text { charting methods, results and conclusions that relate to the } \\
\text { review questions and objectives. }\end{array}$ & 1 \\
\hline \multicolumn{4}{|c|}{ Introduction } \\
\hline Rationale & 3 & $\begin{array}{l}\text { Describe the rationale for the review in the context of what is } \\
\text { already known. Explain why the review questions/objectives } \\
\text { lend themselves to a scoping review approach. }\end{array}$ & $1-2$ \\
\hline Objectives & 4 & $\begin{array}{l}\text { Provide an explicit statement of the questions and objectives } \\
\text { being addressed with reference to their key elements (e.g., } \\
\text { population or participants, concepts and context) or other } \\
\text { relevant key elements used to conceptualize the review } \\
\text { questions and/or objectives. }\end{array}$ & $1-2$ \\
\hline \multicolumn{4}{|c|}{ Methods } \\
\hline Protocol and registration & 5 & $\begin{array}{l}\text { Indicate whether a review protocol exists; state if and where it } \\
\text { can be accessed (e.g., a Web address), and if available, provide } \\
\text { registration information, including the registration number. }\end{array}$ & 2 \\
\hline Eligibility criteria & 6 & $\begin{array}{l}\text { Specify characteristics of the sources of evidence used as } \\
\text { eligibility criteria (e.g., years considered, language and } \\
\text { publication status), and provide a rationale. }\end{array}$ & 3 \\
\hline Information sources * & 7 & $\begin{array}{l}\text { Describe all information sources in the search (e.g., databases } \\
\text { with dates of coverage and contact with authors to identify } \\
\text { additional sources) as well as the date that the most recent } \\
\text { search was executed. }\end{array}$ & 4 \\
\hline Search & 8 & $\begin{array}{l}\text { Present the full electronic search strategy for at least } 1 \\
\text { database, including any limits used, such that it could be } \\
\text { repeated. }\end{array}$ & Appendix B \\
\hline $\begin{array}{c}\text { Selection of sources of } \\
\text { evidence } t\end{array}$ & 9 & $\begin{array}{l}\text { State the process for selecting sources of evidence (i.e., } \\
\text { screening and eligibility) included in the scoping review. }\end{array}$ & 4 \\
\hline
\end{tabular}


Table A1. Cont.

\begin{tabular}{|c|c|c|c|}
\hline Section & Item & PRISMA-ScR CHECKLIST ITEM & $\begin{array}{l}\text { Reported on Page } \\
\text { Number }\end{array}$ \\
\hline Data charting process $\ddagger$ & 10 & $\begin{array}{c}\text { Describe the methods of charting data from the included } \\
\text { sources of evidence (e.g., calibrated forms or forms that have } \\
\text { been tested by the team before their use and whether data } \\
\text { charting was done independently or in duplicate) and any } \\
\text { processes for obtaining and confirming data from } \\
\text { investigators. }\end{array}$ & 4 \\
\hline Data items & 11 & $\begin{array}{l}\text { List and define all variables for which data were sought and } \\
\text { any assumptions and simplifications made. }\end{array}$ & 4 \\
\hline $\begin{array}{l}\text { Critical appraisal of } \\
\text { individual sources of } \\
\text { evidence } \S\end{array}$ & 12 & $\begin{array}{l}\text { If done, provide a rationale for conducting a critical appraisal } \\
\text { of included sources of evidence; describe the methods used } \\
\text { and how this information was used in any data synthesis (if } \\
\text { appropriate). }\end{array}$ & N/A \\
\hline Synthesis of results & 13 & $\begin{array}{l}\text { Describe the methods of handling and summarizing the data } \\
\text { that were charted. }\end{array}$ & 4 \\
\hline \multicolumn{4}{|c|}{ Results } \\
\hline $\begin{array}{l}\text { Selection of sources of } \\
\text { evidence }\end{array}$ & 14 & $\begin{array}{l}\text { Give numbers of sources of evidence screened, assessed for } \\
\text { eligibility and included in the review, with reasons for } \\
\text { exclusions at each stage, ideally using a flow diagram. }\end{array}$ & 4 \\
\hline $\begin{array}{l}\text { Characteristics of sources } \\
\text { of evidence }\end{array}$ & 15 & $\begin{array}{l}\text { For each source of evidence, present characteristics for which } \\
\text { data were charted and provide the citations. }\end{array}$ & Tables 2-6 \\
\hline $\begin{array}{l}\text { Critical appraisal within } \\
\text { sources of evidence }\end{array}$ & 16 & $\begin{array}{l}\text { If done, present data on critical appraisal of included sources } \\
\text { of evidence (see item 12). }\end{array}$ & N/A \\
\hline $\begin{array}{l}\text { Results of individual } \\
\text { sources of evidence }\end{array}$ & 17 & $\begin{array}{l}\text { For each included source of evidence, present the relevant } \\
\text { data that were charted that relate to the review questions and } \\
\text { objectives. }\end{array}$ & Tables 2-6 \\
\hline Synthesis of results & 18 & $\begin{array}{l}\text { Summarize and/or present the charting results as they relate to } \\
\text { the review questions and objectives. }\end{array}$ & $5-40$ \\
\hline \multicolumn{4}{|c|}{ Discussion } \\
\hline Summary of evidence & 19 & $\begin{array}{l}\text { Summarize the main results (including an overview of } \\
\text { concepts, themes and types of evidence available), link to the } \\
\text { review questions and objectives and consider the relevance to } \\
\text { key groups. }\end{array}$ & $40-41$ \\
\hline Limitations & 20 & Discuss the limitations of the scoping review process. & 41 \\
\hline Conclusions & 21 & $\begin{array}{c}\text { Provide a general interpretation of the results with respect to } \\
\text { the review questions and objectives as well as potential } \\
\text { implications and/or next steps. }\end{array}$ & 42 \\
\hline \multicolumn{4}{|c|}{ Funding } \\
\hline Funding & 22 & $\begin{array}{l}\text { Describe sources of funding for the included sources of } \\
\text { evidence as well as sources of funding for the scoping review. } \\
\text { Describe the role of the funders of the scoping review. }\end{array}$ & 43 \\
\hline
\end{tabular}

JBI = Joanna Briggs Institute; PRISMA-ScR = Preferred Reporting Items for Systematic reviews and Meta-Analyses extension for Scoping Reviews. * From where sources of evidence (see second footnote) are compiled, such as bibliographic databases, social media platforms and websites. + A more inclusive/heterogeneous term used to account for the different types of evidence or data sources (e.g., quantitative and/or qualitative research, expert opinion and policy documents) that may be eligible in a scoping review as opposed to only studies. This is not to be confused with information sources (see first footnote). $¥$ The frameworks by Arksey and O'Malley (1) and Levac and colleagues (2) and the JBI guidance $(3,4)$ refer to the process of data extraction in a scoping review as data charting. $\S$ The process of systematically examining research evidence to assess its validity, results and relevance before using it to inform a decision. This term is used for items 12 and 19 instead of "risk of bias" (which is more applicable to systematic reviews of interventions) to include and acknowledge the various sources of evidence that may be used in a scoping review (e.g., quantitative and/or qualitative research, expert opinion and policy document).

\section{Appendix References}

(1) Arksey, H.; O'Malley, L. Scoping studies: Towards a methodological framework. Int. J. Soc. Res. Methodol. 2005, 8, 19-32.

(2) Levac, D.; Colquhoun, H; O’Brien, K.K. Scoping studies: Advancing the methodology. Implement Sci. 2010, 5, 69, doi:10.1186/1748-5908-5-69.

(3) Peters, M.D.; Godfrey, C.M.; Khalil, H.; McInerney, P.; Parker, D.; Soares, C.B. Guidance for conducting systematic scoping reviews. Int. J. Evid. Based Healthc. 2015, 13, 141-146, doi:10.1097/XEB.0000000000000050.

(4) Peters, M.D.J.; Godfrey, C.; McInerney, P.; Baldini Soares, C.; Khalil, H.; Parker, D. Scoping reviews. In Joanna Briggs Institute Reviewer's Manual; Aromataris, E., Munn, Z., Eds.; Joanna Briggs Inst: Adelaide, Australia, 2017. 


\section{Appendix B}

Table A2. Details of the search strategy used in all 4 databases.






\section{References}

1. Whiteford, H.A.; Ferrari, A.J.; Degenhardt, L.; Feigin, V.; Vos, T. The global burden of mental, neurological and substance use disorders: An analysis from the Global Burden of Disease Study 2010. PLoS ONE 2015, 10, e0116820. [CrossRef] [PubMed]

2. Lopez, A.D.; Murray, C.C.J.L. The global burden of disease, 1990-2020. Nat. Med. 1998, 4, 1241-1243. [CrossRef] [PubMed]

3. GBD 2017 DALYs and HALE Collaborators. 'Global, regional, and national disability-adjusted life-years (DALYs) for 359 diseases and injuries and healthy life expectancy (HALE) for 195 countries and territories, 1990-2017: A systematic analysis for the Global Burden of Disease Study 2017. Lancet Lond. Engl. 2018, 392, 1859-1922. [CrossRef]

4. Demyttenaere, K.; Bruffaerts, R.; Posada-Villa, J.; Gasquet, I.; Kovess, V.; Lepine, J.P.; Angermeyer, M.C.; Bernert, S.; De Girolamo, G.; Morosini, P.; et al. Prevalence, severity, and unmet need for treatment of mental disorders in the World Health Organization World Mental Health Surveys. JAMA 2004, 291, 2581-2590. [CrossRef] [PubMed]

5. Chan, J.S.Y.; Liu, G.; Liang, D.; Deng, K.; Wu, J.; Yan, J.H. Special Issue-Therapeutic Benefits of Physical Activity for Mood: A Systematic Review on the Effects of Exercise Intensity, Duration, and Modality. J. Psychol. 2019, 153, 102-125. [CrossRef]

6. Richards, J.; Jiang, X.; Kelly, P.; Chau, J.; Bauman, A.; Ding, D. Don't worry, be happy: Cross-sectional associations between physical activity and happiness in 15 European countries. BMC Public Health 2015, 15, 53. [CrossRef]

7. Schuch, F.B.; Vancampfort, D.; Richards, J.; Rosenbaum, S.; Ward, P.B.; Stubbs, B. Exercise as a treatment for depression: A meta-analysis adjusting for publication bias. J. Psychiatr. Res. 2016, 77, 42-51. [CrossRef]

8. Kelly, P.; Williamson, C.; Niven, A.G.; Hunter, R.; Mutrie, N.; Richards, J. Walking on sunshine: Scoping review of the evidence for walking and mental health. Br. J. Sports Med. 2018, 52, 800-806. [CrossRef]

9. Active Lives. Sport England. Available online: https://www.sportengland.org/know-your-audience/data/ active-lives (accessed on 27 September 2020).

10. Couch to 5K: Week by Week-NHS'. Available online: https://www.nhs.uk/live-well/exercise/couch-to-5kweek-by-week/ (accessed on 28 November 2019).

11. Nonprofit Girls Empowerment Program | Girls on the Run. GOTR. Available online: https://www. girlsontherun.org/ (accessed on 28 November 2019).

12. Parkrun Eases the Loneliness of the Long-Distance Runner | British Journal of General Practice'. Available online: https://bjgp.org/content/64/625/408 (accessed on 28 November 2019).

13. Sifers, S.K.; Shea, D.N. Evaluations of Girls on the Run/Girls on Track to Enhance Self-Esteem and Well-Being. J. Clin. Sport Psychol. 2013, 7, 77-85. [CrossRef]

14. Grunseit, A.; Richards, J.; Merom, D. Running on a high: Parkrun and personal well-being. BMC Public Health 2017, 18, 59. [CrossRef]

15. Parkrun Practice. Available online: https://r1.dotdigital-pages.com/p/49LX-52M/parkrunpractice (accessed on 28 November 2019).

16. Patel, V.; Garrison, P.; Mari, J.D.; Minas, H.; Prince, M.; Saxena, S. The Lancet's Series on Global Mental Health: 1 year on. Lancet 2008, 372, 1354-1357. [CrossRef]

17. Scoping Studies: Towards a Methodological Framework: International Journal of Social Research Methodology: Vol 8, No 1'. Available online: https://www.tandfonline.com/doi/full/10.1080/ 1364557032000119616 (accessed on 27 September 2019).

18. Tricco, A.C.; Lillie, E.; Zarin, W.; O’Brien, K.K.; Colquhoun, H.; Levac, D.; Moher, D.; Peters, M.D.; Horsley, T.; Weeks, L.; et al. PRISMA Extension for Scoping Reviews (PRISMA-ScR): Checklist and Explanation. Ann. Intern. Med. 2018, 169, 467. [CrossRef]

19. American Psychological Association. Diagnostic and Statistical Manual of Mental Disorders (DSM-5®); American Psychiatric Pub: Washington, DC, USA, 2013.

20. Physical Activity Guidelines Advisory Committee Report, 2008 to the Secretary of Health and Human Services: (525442010-001); American Psychological Association: Worcester, MA, USA, 2008. [CrossRef]

21. Zulkosky, K. Self-Efficacy: A Concept Analysis. Nurs. Forum (Auckl.) 2009, 44, 93-102. [CrossRef]

22. Ridner, S.H. Psychological distress: Concept analysis. J. Adv. Nurs. 2004, 45, 536-545. [CrossRef] [PubMed] 
23. Fairburn, C.G.; Brownell, K.D. Eating Disorders and Obesity: A Comprehensive Handbook; Guilford Press: New York, NY, USA, 2005.

24. Pressman, S.D.; Cohen, S. Does positive affect influence health? Psychol. Bull. 2005, 131, 925-971. [CrossRef]

25. Goodman, A. Addiction: Definition and implications. Br. J. Addict. 1990, 85, 1403-1408. [CrossRef]

26. Ryff, C.D. Eudaimonic well-being and health: Mapping consequences of self-realization. In The Best within Us: Positive Psychology Perspectives on Eudaimonia; American Psychological Association: Washington, DC, USA, 2013; pp. 77-98.

27. Kinch, J.W. A Formalized Theory of the Self-Concept. Am. J. Sociol. 1963, 68, 481-486. [CrossRef]

28. Lane, A.M.; Terry, P.C. The Nature of Mood: Development of a Conceptual Model with a Focus on Depression. J. Appl. Sport Psychol. 2000, 12, 16-33. [CrossRef]

29. Wilson, V.E.; Morley, N.C.; Bird, E.I. Mood profiles of marathon runners, joggers and non-exercisers. Percept. Mot. Skills 1980, 50, 117-118. [CrossRef]

30. Joesting, J. Running and Depression. Percept. Mot. Skills 1981, 52, 442. [CrossRef]

31. Jorgenson, D.E.; Jorgenson, C.B. Perceived Effects of Running/Jogging: A Social Survey of Three Clubs. Int. Rev. Sport Sociol. 1981, 16, 75-85. [CrossRef]

32. Valliant, P.M.; Bennie, F.A.; Valiant, J.J. Do marathoners differ from joggers in personality profile: A sports psychology approach. J. Sports Med. Phys. Fit. 1981, 21, 62-67.

33. Francis, K.T.; Carter, R. Psychological characteristic of joggers. J. Sports Med. Phys. Fit. 1982, 22, $386-391$.

34. Hailey, B.J.; Bailey, L.A. Negative addiction in runners: A quantitative approach. J. Sport Behav. 1982, 5, 150-154.

35. Callen, K.E. Mental and emotional aspects of long-distance running. Psychosomatics 1983, 24, $133-134$. [CrossRef]

36. Galle, P.C.; Freeman, E.W.; Galle, M.G.; Huggins, G.R.; Sondheimer, S.J. Physiologic and psychologic profiles in a survey of women runners. Fertil. Steril. 1983, 39, 633-639. [CrossRef]

37. Lobstein, D.D.; Mosbacher, B.J.; Ismail, A.H. Depression as a powerful discriminator between physically active and sedentary middle-aged men. J. Psychosom. Res. 1983, 27, 69-76. [CrossRef]

38. Rudy, E.B.; Estok, P.J. Intensity of jogging: Its relationship to selected physical and psychosocial variables in women. West. J. Nurs. Res. 1983, 5, 325-336. [CrossRef]

39. Goldfarb, L.A.; Plante, T.G. Fear of fat in runners: An examination of the connection between anorexia nervosa and distance running. Psychol. Rep. 1984, 55, 296. [CrossRef]

40. Guyot, G.W.; Fairchild, L.; Nickens, J. Death concerns of runners and nonrunners. J. Sports Med. Phys. Fit. 1984, 24, 139-143.

41. Rape, R.N. Running and Depression. Percept. Mot. Skills 1987, 64 (Suppl. 3), 1303-1310. [CrossRef]

42. Weight, L.M.; Noakes, T.D. Is running an analog of anorexia?: A survey of the incidence of eating disorders in female distance runners. Med. Sci. Sports Exerc. 1987, 19, 213-217. [CrossRef] [PubMed]

43. Chan, C.S.; Grossman, H.Y. Psychological effects of running loss on consistent runners. Percept. Mot. Skills 1988, 66, 875-883. [CrossRef] [PubMed]

44. Frazier, S.E. Mood state profiles of chronic exercisers with differing abilities. Int. J. Sport Psychol. 1988, 19, 65-71.

45. Lobstein, D.D.; Ismail, A.H.; Rasmussen, C.L. Beta-endorphin and components of emotionality discriminate between physically active and sedentary men. Biol. Psychiatry 1989, 26, 3-14. [CrossRef]

46. Lobstein, D.D.; Rasmussen, C.L.; Dunphy, G.E.; Dunphy, M.J. Beta-endorphin and components of depression as powerful discriminators between joggers and sedentary middle-aged men. J. Psychosom. Res. 1989, 33, 293-305. [CrossRef]

47. Nouri, S.; Beer, J. Relations of moderate physical exercise to scores on hostility, aggression, and aggression, and trait-anxiety. Percept. Mot. Skills 1989, 68 Pt 2, 1191-1194. [CrossRef]

48. Chan, D.W.; Lai, B. Psychological aspects of long-distance running among Chinese male runners in Hong Kong. Int. J. Psychosom. Off. Publ. Int. Psychosom. Inst. 1990, 37, 30-34.

49. Chapman, C.L.; de Castro, J.M. Running addiction: Measurement and associated psychological characteristics. J. Sports Med. Phys. Fit. 1990, 30, 283-290.

50. Guyot, W.G. Psychological and medical factors associated with pain running. J. Sports Med. Phys. Fit. 1991, 31, 452-460. 
51. Maresh, C.M.; Sheckley, B.G.; Allen, G.J.; Camaione, D.N.; Sinatra, S.T. Middle age male distance runners: Physiological and psychological profiles. J. Sports Med. Phys. Fit. 1991, 31, 461-469.

52. Gleaves, D.H.; Williamson, D.A.; Fuller, R.D. Bulimia nervosa symptomatology and body image disturbance associated with distance running and weight loss. Br. J. Sports Med. 1992, 26, 157-160. [CrossRef] [PubMed]

53. Coen, S.P.; Ogles, B.M. Psychological characteristics of the obligatory runner: A critical examination of the anorexia analogue hypothesis. J. Sport Exerc. Psychol. 1993, 15, 338-354. [CrossRef]

54. Furst, D.M.; Germone, K. Negative addiction in male and female runners and exercisers. Percept. Mot. Skills 1993, 77, 192-194. [CrossRef]

55. Masters, K.S.; Ogles, B.M.; Jolton, J.A. The development of an instrument to measure motivation for marathon running: The Motivations of Marathoners Scales (MOMS). Res. Q. Exerc. Sport 1993, 64, 134-143. [CrossRef]

56. Pierce, E.F.; McGowan, R.W.; Lynn, T.D. Exercise dependence in relation to competitive orientation of runners. J. Sports Med. Phys. Fitness 1993, 33, 189-193.

57. Klock, S.C.; DeSouza, M.J. Eating disorder characteristics and psychiatric symptomatology of eumenorrheic and amenorrheic runners. Int. J. Eat. Disord. 1995, 17, 161-166. [CrossRef]

58. Thornton, E.W.; Scott, S.E. Motivation in the committed runner: Correlations between self-report scales and behaviour. Health Promot. Int. 1995, 10, 177-184. [CrossRef]

59. Powers, P.S.; Schocken, D.D.; Boyd, F.R. Comparison of habitual runners and anorexia nervosa patients. Int. J. Eat. Disord. 1998, 23, 133-143. [CrossRef]

60. Slay, H.A.; Hayaki, J.; Napolitano, M.A.; Brownell, K.D. Motivations for running and eating attitudes in obligatory versus nonobligatory runners. Int. J. Eat. Disord. 1998, 23, 267-275. [CrossRef]

61. Ryujin, D.H.; Breaux, C.; Marks, A.D. Symptoms of eating disorders among female distance runners: Can the inconsistencies be unraveled? Women Health 1999, 30, 71-83. [CrossRef] [PubMed]

62. Leedy, G. Commitment to Distance Running: Coping Mechanisms or Addiction. J. Sport Behav. Mob. Ala 2000, 23, 255-270.

63. Edwards, S.D.; Ngcobo, H.S.; Edwards, D.J.; Palavar, K. Exploring the relationship between physical activity, psychological well-being and physical self- perception in different exercise groups. South Afr. J. Res. Sport Phys. Educ. Recreat. 2005, 27, 59-74. [CrossRef]

64. Schnohr, P.; Kristensen, T.S.; Prescott, E.; Scharling, H. Stress and life dissatisfaction are inversely associated with jogging and other types of physical activity in leisure time-The Copenhagen City Heart Study. Scand. J. Med. Sci. Sports 2005, 15, 107-112. [CrossRef] [PubMed]

65. Strachan, S.M.; Woodgate, J.; Brawley, L.R.; Tse, A. The Relationship of Self-Efficacy and Self-Identity to Long-Term Maintenance of Vigorous Physical Activity. J. Appl. Biobehav. Res. 2005, 10, 98-112. [CrossRef]

66. Galper, D.I.; Trivedi, M.H.; Barlow, C.E.; Dunn, A.L.; Kampert, J.B. Inverse association between physical inactivity and mental health in men and women. Med. Sci. Sports Exerc. 2006, 38, 173-178. [CrossRef]

67. Luszczynska, A.; Mazurkiewicz, M.; Ziegelmann, J.P.; Schwarzer, R. Recovery self-efficacy and intention as predictors of running or jogging behavior: A cross-lagged panel analysis over a two-year period. Psychol. Sport Exerc. 2007, 8, 247-260. [CrossRef]

68. Smith, D.; Wright, C.; Winrow, D. Exercise dependence and social physique anxiety in competitive and non-competitive runners. Int. J. Sport Exerc. Psychol. 2010, 8, 61-69. [CrossRef]

69. Gapin, J.I.; Petruzzello, S.J. Athletic identity and disordered eating in obligatory and non-obligatory runners. J. Sports Sci. 2011, 29, 1001-1010. [CrossRef]

70. Wadas, G.; DeBeliso, M. Disordered eating, eating attitudes, and reasons for exercise among male high school cross country runners. Sport J. 2014, 17. Available online: https://www.cabdirect.org/cabdirect/abstract/ 20153072464 (accessed on 15 July 2020).

71. Download Citation of The Relationship between Motivations, Perceived Control, and Mental Toughness Among Marathon Runners. ResearchGate. Available online: https://www.researchgate.net/publication/ 325793259_The_relationship_between_motivations_perceived_control_and_mental_toughness_among_ marathon_runners (accessed on 15 July 2020).

72. Lucidi, F.; Pica, G.; Mallia, L.; Castrucci, E.; Manganelli, S.; Bélanger, J.J.; Pierro, A. Running away from stress: How regulatory modes prospectively affect athletes' stress through passion. Scand. J. Med. Sci. Sports 2016, 26, 703-711. [CrossRef] [PubMed] 
73. Batmyagmar, D.; Kundi, M.; Ponocny-Seliger, E.; Lukas, I.; Lehrner, J.; Haslacher, H.; Winker, R. High intensity endurance training is associated with better quality of life, but not with improved cognitive functions in elderly marathon runners. Sci. Rep. 2019, 9, 4629. [CrossRef]

74. Cleland, V.; Nash, M.; Sharman, M.J.; Claflin, S. Exploring the Health-Promoting Potential of the "parkrun" Phenomenon: What Factors are Associated With Higher Levels of Participation? Am. J. Health Promot. AJHP 2019, 33, 13-23. [CrossRef]

75. Lukács, A.; Sasvári, P.; Varga, B.; Mayer, K. Exercise addiction and its related factors in amateur runners. J. Behav. Addict. 2019, 8, 343-349.

76. Solmon, M.; Stewart, L. Changes in self-efficacy and affect during a 15-week marathon training program. Int. J. Sport Psychol. 2013, 44, 55-68.

77. Nowlis, D.P.; Greenberg, N. Empirical description of effects of exercise on mood. Percept. Mot. Skills 1979, 49, 1001-1002. [CrossRef]

78. Wilson, V.E.; Berger, B.G.; Bird, E.I. Effects of running and of an exercise class on anxiety. Percept. Mot. Skills 1981, 53, 472-474. [CrossRef]

79. Markoff, R.A.; Ryan, P.; Young, T. Endorphins and mood changes in long-distance running. Med. Sci. Sports Exerc. 1982, 14, 11-15. [CrossRef] [PubMed]

80. Thaxton, L. Physiological and Psychological Effects of Short-term Exercise Addiction on Habitual Runners. J. Sport Exerc. Psychol. 1982, 4, 73-80. [CrossRef]

81. McGowan, R.W.; Pierce, E.F.; Jordan, D. Mood alterations with a single bout of physical activity. Percept. Mot. Skills 1991, 72 Pt 2, 1203-1209. [CrossRef]

82. Goode, K.T.; Roth, D.L. Factor Analysis of Cognitions during Running: Association with Mood Change. J. Sport Exerc. Psychol. 1993, 15, 375-389. [CrossRef]

83. Morris, M.; Salmon, P. Qualitative and quantitative effects of running on mood. J. Sports Med. Phys. Fit. 1994, 34, 284-291.

84. Rudolph, D.L.; Butki, B.D. Self-efficacy and affective responses to short bouts of exercise. J. Appl. Sport Psychol. 1998, 10, 268-280. [CrossRef]

85. Cox, R.H.; Thomas, T.R.; Davis, J.E. Positive and negative affect associated with an acute bout of aerobic exercise. J. Exerc. Physiol. Online 2001, 4, 13-20.

86. O'Halloran, P.D.; Murphy, G.C.; Webster, K.E. Measure of beliefs about improvements in mood associated with exercise. Psychol. Rep. 2002, 90 Pt 1, 834-840. [CrossRef]

87. Szabo, A. The Acute Effects of Humor and Exercise on Mood and Anxiety. J. Leis. Res. 2003, 35, $152-162$. [CrossRef]

88. O'Halloran, P.D.; Murphy, G.C.; Webster, K. Mood during a 60-minute treadmill run: Timing and type of mood change. Int. J. Sport Psychol. 2004, 35, 309-327.

89. Robbins, L.B.; Pender, N.J.; Ronis, D.L.; Kazanis, A.S.; Pis, M.B. Physical activity, self-efficacy, and perceived exertion among adolescents. Res. Nurs. Health 2004, 27, 435-446. [CrossRef] [PubMed]

90. Pretty, J.; Peacock, J.; Sellens, M.; Griffin, M. The mental and physical health outcomes of green exercise. Int. J. Environ. Health Res. 2005, 15, 319-337. [CrossRef]

91. Hoffman, M.D.; Hoffman, D.R. Exercisers achieve greater acute exercise-induced mood enhancement than nonexercisers. Arch. Phys. Med. Rehabil. 2008, 89, 358-363. [CrossRef]

92. Kwan, B.M.; Bryan, A.D. Affective response to exercise as a component of exercise motivation: Attitudes, norms, self-efficacy, and temporal stability of intentions. Psychol. Sport Exerc. 2010, 11, 71-79. [CrossRef] [PubMed]

93. Weinstein, A.A.; Deuster, P.A.; Francis, J.L.; Beadling, C.; Kop, W.J. The Role of Depression in Short-Term Mood and Fatigue Responses to Acute Exercise. Int. J. Behav. Med. 2010, 17, 51-57. [CrossRef]

94. Anderson, R.J.; Brice, S. The mood-enhancing benefits of exercise: Memory biases augment the effect. Psychol. Sport Exerc. 2011, 12, 79-82. [CrossRef]

95. Kane, I.; Robertson, R.; Fertman, C.; Nagle, E.; McConnaha, W.; Rabin, B. Self-efficacy and enjoyment of middle school children performing the Progressive Aerobic Cardiovascular Endurance Run (PACER). Percept. Mot. Skills 2013, 117, 470-483. [CrossRef]

96. Szabo, A.; Abrahám, J. The psychological benefits of recreational running: A field study. Psychol. Health Med. 2013, 18, 251-261. [CrossRef] 
97. McDowell, C.P.; Campbell, M.J.; Herring, M.P. Sex-Related Differences in Mood Responses to Acute Aerobic Exercise. Med. Sci. Sports Exerc. 2016, 48, 1798-1802. [CrossRef]

98. Rogerson, M.; Brown, D.K.; Sandercock, G.; Wooller, J.-J.; Barton, J. A comparison of four typical green exercise environments and prediction of psychological health outcomes. Perspect. Public Health 2016, 136, 171-180. [CrossRef]

99. Edwards, M.K.; Rhodes, R.E.; Loprinzi, P.D. A Randomized Control Intervention Investigating the Effects of Acute Exercise on Emotional Regulation. Am. J. Health Behav. 2017, 41, 534-543. [CrossRef]

100. Wildmann, J.; Krüger, A.; Schmole, M.; Niemann, J.; Matthaei, H. Increase of circulating beta-endorphin-like immunoreactivity correlates with the change in feeling of pleasantness after running. Life Sci. 1986, 38, 997-1003. [CrossRef]

101. O'Connor, P.J.; Carda, R.D.; Graf, B.K. Anxiety and intense running exercise in the presence and absence of interpersonal competition. Int. J. Sports Med. 1991, 12, 423-426. [CrossRef]

102. Nabetani, T.; Tokunaga, M. The effect of short-term (10- and 15-min) running at self-selected intensity on mood alteration. J. Physiol. Anthropol. Appl. Hum. Sci. 2001, 20, 231-239. [CrossRef] [PubMed]

103. Bodin, M.; Hartig, T. Does the outdoor environment matter for psychological restoration gained through running? Psychol. Sport Exerc. 2003, 4, 141-153. [CrossRef]

104. Butryn, T.M.; Furst, D.M. The effects of park and urban settings on the moods and cognitive strategies of female runners. J. Sport Behav. 2003, 26, 335-355.

105. Kerr, J.H.; Fujiyama, H.; Sugano, A.; Okamura, T.; Chang, M.; Onouha, F. Psychological responses to exercising in laboratory and natural environments. Psychol. Sport Exerc. 2006, 7, 345-359. [CrossRef]

106. Rose, E.A.; Parfitt, G. Exercise experience influences affective and motivational outcomes of prescribed and self-selected intensity exercise. Scand. J. Med. Sci. Sports 2012, 22, 265-277. [CrossRef]

107. Reed, K.; Wood, C.; Barton, J.; Pretty, J.N.; Cohen, D.; Sandercock, G.R.H. A repeated measures experiment of green exercise to improve self-esteem in UK school children. PLoS ONE 2013, 8, e69176. [CrossRef]

108. Krotee, M.L. The Effects of Various Physical Activity Situational Settings on the Anxiety Level of Children. J. Sport Behav. Mob. Ala 1980, 3, 158-164.

109. Harte, J.L.; Eifert, G.H. The effects of running, environment, and attentional focus on athletes' catecholamine and cortisol levels and mood. Psychophysiology 1995, 32, 49-54. [CrossRef]

110. Berger, B.; Owen, D.; Motl, R.; Parks, L. Relationship between expectancy of psychological benefits and mood alteration in joggers. Int. J. Sport Psychol. 1998, 29, 1-16.

111. Markowitz, S.M.; Arent, S.M. The exercise and affect relationship: Evidence for the dual-mode model and a modified opponent process theory. J. Sport Exerc. Psychol. 2010, 32, 711-730. [CrossRef]

112. Lion, L.S. Psychological effects of jogging: A preliminary study. Percept. Mot. Skills 1978, 47 Pt 2, $1215-1218$. [CrossRef]

113. Blue, F.R. Aerobic running as a treatment for moderate depression. Percept. Mot. Skills 1979, 48, 228. [CrossRef] [PubMed]

114. Young, R.J. The effect of regular exercise on cognitive functioning and personality. Br. J. Sports Med. 1979, 13, 110-117. [CrossRef]

115. Blumenthal, J.A.; Williams, R.S.; Needels, T.L.; Wallace, A.G. Psychological changes accompany aerobic exercise in healthy middle-aged adults. Psychosom. Med. 1982, 44, 529-536. [CrossRef] [PubMed]

116. Trujillo, C.M. The effect of weight training and running exercise intervention programs on the self-esteem of college women. Int. J. Sport Psychol. 1983, 14, 162-173.

117. Tuckman, B.W.; Hinkle, J.S. An experimental study of the physical and psychological effects of aerobic exercise on schoolchildren. Health Psychol. Off. J. Div. Health Psychol. Am. Psychol. Assoc. 1986, 5, 197-207. [CrossRef]

118. Doyne, E.J.; Ossip-Klein, D.J.; Bowman, E.D.; Osborn, K.M.; McDougall-Wilson, I.B.; Neimeyer, R.A. Running versus weight lifting in the treatment of depression. J. Consult. Clin. Psychol. 1987, 55, 748-754. [CrossRef] [PubMed]

119. Fremont, J.; Craighead, L.W. Aerobic exercise and cognitive therapy in the treatment of dysphoric moods. Cogn. Ther. Res. 1987, 11, 241-251. [CrossRef]

120. Hannaford, C.P.; Harrell, E.H.; Cox, K. Psychophysiological Effects of a Running Program on Depression and Anxiety in a Psychiatric Population. Psychol. Rec. 1988, 38, 37-48. [CrossRef] 
121. Long, B.C.; Haney, C.J. Long-Term Follow-up of Stressed Working Women: A Comparison of Aerobic Exercise and Progressive Relaxation. J. Sport Exerc. Psychol. 1988, 10, 461-470. [CrossRef]

122. Simons, C.W.; Birkimer, J.C. An exploration of factors predicting the effects of aerobic conditioning on mood state. J. Psychosom. Res. 1988, 32, 63-75. [CrossRef]

123. Moses, J.; Steptoe, A.; Mathews, A.; Edwards, S. The effects of exercise training on mental well-being in the normal population: A controlled trial. J. Psychosom. Res. 1989, 33, 47-61. [CrossRef]

124. Ossip-Klein, D.J.; Doyne, E.J.; Bowman, E.D.; Osborn, K.M.; McDougall-Wilson, I.B.; Neimeyer, R.A. Effects of running or weight lifting on self-concept in clinically depressed women. J. Consult. Clin. Psychol. 1989, 57, 158-161. [CrossRef] [PubMed]

125. Morris, M.; Steinberg, H.; Sykes, E.A.; Salmon, P. Effects of temporary withdrawal from regular running. J. Psychosom. Res. 1990, 34, 493-500. [CrossRef]

126. Friedman, E.; Berger, B.G. Influence of gender, masculinity, and femininity on the effectiveness of three stress reduction techniques: Jogging, relaxation response, and group interaction. J. Appl. Sport Psychol. 1991, 3, 61-86. [CrossRef]

127. Williams, T.J.; Krahenbuhl, G.S.; Morgan, D.W. Mood state and running economy in moderately trained male runners. Med. Sci. Sports Exerc. 1991, 23, 727-731. [CrossRef]

128. Kerr, J.H.; Vlaswinkel, E.H. Self-reported mood and running under natural conditions. Work Stress 1993, 7, 161-177. [CrossRef]

129. Long, B.C. Aerobic conditioning (jogging) and stress inoculation interventions: An exploratory study of coping. Int. J. Sport Psychol. 1993, 24, 94-109.

130. Berger, B.G.; Friedman, E. Comparison of Jogging, the Relaxation Response, and Group Interaction for Stress Reduction. J. Sport Exerc. Psychol. 1988, 10, 431-447. [CrossRef]

131. Berger, B.G.; Owen, D.R. Relation of low and moderate intensity exercise with acute mood change in college joggers. Percept. Mot. Skills 1998, 87, 611-621. [CrossRef]

132. Szabo, A.; Frenkl, R.; Janek, G.; Kálmán, L.; Lászay, D. Runners' anxiety and mood on running and non-running days: An in situ daily monitoring study. Psychol. Health Med. 1998, 3, 193-199. [CrossRef]

133. Broman-Fulks, J.J.; Berman, M.E.; Rabian, B.A.; Webster, M.J. Effects of aerobic exercise on anxiety sensitivity. Behav. Res. Ther. 2004, 42, 125-136. [CrossRef]

134. Haffmans, P.M.J.; Kleinsman, A.C.M.; van Weelden, C.; Huijbrechts, I.P.A.M.; Hoencamp, E. Comparing running therapy with physiotraining therapy in the treatment of mood disorders. Acta Neuropsychiatr. 2006, 18, 173-176. [CrossRef] [PubMed]

135. Thornton, E.; Cronholm, P.; McCray, L.; Webner, D. Does Marathon Training Adversely Affect Baseline Anxiety Levels? AMAA J. 2008, 21,5-9.

136. Scholz, U.; Nagy, G.; Schüz, B.; Ziegelmann, J.P. The role of motivational and volitional factors for self-regulated running training: Associations on the between- and within- person level. Br. J. Soc. Psychol. 2008, 47 Pt 3, 421-439. [CrossRef]

137. Kalak, N.; Gerber, M.; Kirov, R.; Mikoteit, T.; Yordanova, J.; Pühse, U. Daily morning running for 3 weeks improved sleep and psychological functioning in healthy adolescents compared with controls. J. Adolesc. Health Off. Publ. Soc. Adolesc. Med. 2012, 51, 615-622. [CrossRef]

138. Inoue, Y.; Funk, D.; Jordan, J.S. The role of running involvement in creating self-sufficiency for homeless individuals through a community-based running program. J. Sport Manag. 2013, 27, 439-452. [CrossRef]

139. Doose, M.; Ziegenbein, M.; Hoos, O.; Reim, D.; Stengert, W.; Hoffer, N.; Vogel, C.; Ziert, Y.; Sieberer, M. Self-selected intensity exercise in the treatment of major depression: A pragmatic RCT. Int. J. Psychiatry Clin. Pract. 2015, 19, 266-275. [CrossRef]

140. von Haaren, B.; Haertel, S.; Stumpp, J.; Hey, S.; Ebner-Priemer, U. Reduced emotional stress reactivity to a real-life academic examination stressor in students participating in a 20-week aerobic exercise training: A randomised controlled trial using Ambulatory Assessment. Psychol. Sport Exerc. 2015, 20, 67-75. [CrossRef]

141. Kahan, D.; McKenzie, T.L. Physical Activity and Psychological Correlates During an After-School Running Club. Am. J. Health Educ. 2018, 49, 113-123. [CrossRef]

142. Keating, L.E.; Becker, S.; McCabe, K.; Whattam, J.; Garrick, L.; Sassi, R.B.; Frey, B.N.; McKinnon, M.C. Effects of a 12-week running programme in youth and adults with complex mood disorders. BMJ Open Sport Exerc. Med. 2018, 4, e000314. [CrossRef] [PubMed] 
143. Nezlek, J.B.; Cypryańska, M.; Cypryański, P.; Chlebosz, K.; Jenczylik, K.; Sztachańska, J.; Zalewska, A.M. Within-Person Relationships Between Recreational Running and Psychological Well-Being. J. Sport Exerc. Psychol. 2018, 40, 146-152. [CrossRef] [PubMed]

144. Kruisdijk, F.; Hopman-Rock, M.; Beekman, A.T.F.; Hendriksen, I. EFFORT-D: Results of a randomised controlled trial testing the EFFect of running therapy on depression. BMC Psychiatry 2019, 19, 170. [CrossRef]

145. Kruisdijk, F.; Hendriksen, I.; Tak, E.; Beekman, A.-J.; Hopman-Rock, M. EFFORT-D study process evaluation: Challenges in conducting a trial into the effects of running therapy in patients with major depressive disorder. Ann. Gen. Psychiatry 2018, 17, 10. [CrossRef]

146. Krogh, J.; Nordentoft, M.; Sterne, J.A.C.; Lawlor, D.A. The effect of exercise in clinically depressed adults: Systematic review and meta-analysis of randomized controlled trials. J. Clin. Psychiatry 2011, 72, 529-538. [CrossRef]

147. Stanton, R.; Reaburn, P. Exercise and the treatment of depression: A review of the exercise program variables. J. Sci. Med. Sport 2014, 17, 177-182. [CrossRef]

148. Lubans, D.; Richards, J.; Hillman, C.; Faulkner, G.; Beauchamp, M.; Nilsson, M.; Kelly, P.; Smith, J.; Raine, L.; Biddle, S. Physical Activity for Cognitive and Mental Health in Youth: A Systematic Review of Mechanisms. Pediatrics 2016, 138, e20161642. [CrossRef]

149. Greist, J.H.; Klein, M.H.; Eischens, R.R.; Faris, J.; Gurman, A.S.; Morgan, W.P. Running as treatment for depression. Compr. Psychiatry 1979, 20, 41-54. [CrossRef]

150. Vezina, M.L.; Ruegger, R.H. THE PSYCHOLOGY OF RUNNING: Implications for nursing and health. Nurs. Forum (Auckl.) 1980, 19, 108-121. [CrossRef] [PubMed]

151. Hinkle, J.S. Aerobic running behaviour and psychotherapeutics: Implications for sports counseling and psychology. J. Sport Behav. 1992, 15, 263-277.

152. Weinstein, W.S.; Meyers, A.W. Running as Treatment for Depression: Is It Worth It? J. Sport Exerc. Psychol. 1983, 5, 288-301. [CrossRef]

153. Katz, J.L. Long-distance running, anorexia nervosa, and bulimia: A report of two cases. Compr. Psychiatry 1986, 27, 74-78. [CrossRef]

154. Prussin, R.A.; Harvey, P.D. Depression, dietary restraint, and binge eating in female runners. Addict. Behav. 1991, 16, 295-301. [CrossRef]

155. Yates, A.; Shisslak, C.M.; Allender, J.; Crago, M.; Leehey, K. Comparing obligatory to nonobligatory runners. Psychosomatics 1992, 33, 180-189. [CrossRef]

156. Pierce, E.F.; Rohaly, K.A.; Fritchley, B. Sex differences on exercise dependence for men and women in a marathon road race. Percept. Mot. Skills 1997, 84 Pt 1, 991-994. [CrossRef]

157. Yatham, L.N.; Kennedy, S.H.; Parikh, S.V.; Schaffer, A.; Bond, D.J.; Frey, B.N.; Sharma, V.; Goldstein, B.I.; Rej, S.; Beaulieu, S.; et al. Canadian Network for Mood and Anxiety Treatments (CANMAT) and International Society for Bipolar Disorders (ISBD) 2018 guidelines for the management of patients with bipolar disorder. Bipolar Disord. 2018, 20, 97-170. [CrossRef]

158. Scott, J.; Pope, M. Nonadherence with mood stabilizers: Prevalence and predictors. J. Clin. Psychiatry 2002, 63, 384-390. [CrossRef]

159. Keller, M.B.; Lavori, P.W.; Mueller, T.I.; Endicott, J.; Coryell, W.; Hirschfeld, R.M.; Shea, T. Time to recovery, chronicity, and levels of psychopathology in major depression. A 5-year prospective follow-up of 431 subjects. Arch. Gen. Psychiatry 1992, 49, 809-816. [CrossRef]

160. Kennedy, S.H.; Lam, R.W.; McIntyre, R.S.; Tourjman, S.V.; Bhat, V.; Blier, P.; Hasnain, M.; Jollant, F.; Levitt, A.J.; MacQueen, G.M.; et al. Canadian Network for Mood and Anxiety Treatments (CANMAT) 2016 Clinical Guidelines for the Management of Adults with Major Depressive Disorder: Section 3. Pharmacological Treatments. Can. J. Psychiatry Rev. Can. Psychiatry 2016, 61, 540-560. [CrossRef]

161. Thomas, J.; Thirlaway, K.; Bowes, N.; Meyers, R. Effects of combining physical activity with psychotherapy on mental health and well-being: A systematic review. J. Affect. Disord. 2020, 265, 475-485. [CrossRef]

162. Schuch, F.B.; Vancampfort, D.; Rosenbaum, S.; Richards, J.; Ward, P.B.; Veronese, N.; Solmi, M.; Cadore, E.L.; Stubbs, B. Exercise for depression in older adults: A meta-analysis of randomized controlled trials adjusting for publication bias. Rev. Bras. Psiquiatr. 2016, 38, 247-254. [CrossRef] [PubMed] 
163. Children Fit for Life. The Daily Mile. Available online: https://thedailymile.co.uk (accessed on 18 September 2020).

Publisher's Note: MDPI stays neutral with regard to jurisdictional claims in published maps and institutional affiliations.

(C) 2020 by the authors. Licensee MDPI, Basel, Switzerland. This article is an open access article distributed under the terms and conditions of the Creative Commons Attribution (CC BY) license (http://creativecommons.org/licenses/by/4.0/). 